Policy Bridge:

\title{
Air Quality Impacts from Oil and Natural Gas Development in Colorado
}

3

4

11

12

13

14

15

16

17

18

19

\section{Detlev Helmig ${ }^{1,2, *}$}

${ }^{1}$ Institute of Arctic and Alpine Research, 4001 Discovery Dr., University of Colorado Boulder, CO 80309, USA

${ }^{2}$ Boulder A.I.R. L.L.C., 2820 Lafayette Dr., Boulder, CO 80305, USA

*Detlev.Helmig@colorado.edu

December 10, 2019

Manuscript in press for publication in Elementa - Science of the Anthropocene Special Forum 'Oil and Natural Gas Development: Air, Climate Science, and Policy'

http://doi.org/10.1525/elementa.398 


\section{List of Contents}

21

22 Abstract

Page 3

23 Introduction

Page 3

24 Resources Utilized and Published Work

Page 5

25 Monitoring Networks

Page 13

26 Nitrogen Oxides

Page 13

27 Methane

Page 13

28 Volatile Organic Compounds

Page 15

29 Ozone

Page 17

30 Particulates

Page 21

31 Atmospheric Circulation Influences in the NCFR

Page 22

32 Inventories

Page 23

33 Changes in O\&NG Emissions and Atmospheric Concentrations

Page 25

34 Oil and Natural Gas Emissions and Air Quality

Page 26

35 Recommendations

Page 30

$36 \quad$ Literature Cited

Page 32 


\section{Abstract}

The rise of hydraulic fracturing techniques has fostered rapid growth of oil and natural gas extraction in areas across the United States. In the Denver-Julesburg Basin (DJB), which mostly overlaps with Weld County in the Northern Colorado Front Range (NCFR) north of the City of Denver Metropolitan Area (DMA), the well drilling has increasingly approached, and in many instances moved into urban residential areas. During the same time, the region has also experienced steady population growth. The DMA NCFR has been in exceedance of the ozone U.S. National Ambient Air Quality Standard (NAAQS) and was designated a non-attainment area of the standard in 2007. Despite State efforts to curb precursors, ozone has consistently remained above the standard. A growing number of atmospheric studies has provided an ever increasing body of literature for assessing influences from O\&NG industry emissions on air quality in the DMA-NCFR. This paper provides 1. An overview of available literature on O\&NG influences on the regional air quality, 2. A summary of the pertinent findings presented in these works, 3 . An assessment of the most important pollutants and air quality impacts, 4. Identification of knowledge and monitoring gaps, and 5 . Recommendations for future research and policy.

\section{Introduction}

The development of hydraulic fracturing techniques has made it profitable to extract petroleum hydrocarbons from geologic shale formations. The application of this technology has caused a surge in new oil and natural gas (O\&NG) drilling in shale basins across the United States, including in Colorado, where most of the activity has been in the Denver Julesburg Basin (DJB). In 2017, there were over 53,000 active O\&NG wells in Colorado. The O\&NG development is concentrated in a number of lower elevation basins, with $\approx 24,000$ wells (January 2018) located in Weld County in the DJB, which in 2017 produced $\approx 90 \%$ of the oil in Colorado [Swain, 2018]. From 2010-2018, annual natural gas production in Weld County increased by a factor of 3.5, and annual oil production by a factor of $\approx 6.5$ [Drilling-Edge, 2019]. Some of the growth of the O\&NG industry has occurred within the periphery of urban and residential areas, raising concerns within communities. Proximity to O\&NG operations has been associated with human health effects, with atmospheric emissions being a primary pathway of exposure. Types and causes of emissions are dependent on multiple variables and stages of the well development, and can arise, for instance, from heavy equipment use at the site and vehicle traffic, power generation, drilling operation, spillage and evaporation of fracking fluid, flowback of the extracted petroleum products, flaring, and fugitive or controlled hydrocarbon emissions during loading and transportation [Adgate et al., 2014]. Fracking fluid is a mixture of a multitude of synthetic chemicals, with the composition typically kept proprietary by operators. Silica, added to the fracking fluid, dust, and soot/particles from diesel engines contribute to particulate exposure. Gaseous emissions arise from fracking fluid additives, controlled venting, flaring, and leakage of equipment, storage tanks, and pipelines. Directly emitted gaseous pollutants of concern for human health are hydrogen sulfide and petroleum constituents, including aromatic and polycyclic aromatic hydrocarbons. Combustion processes cause emissions of carbon monoxide, nitrogen oxides, volatile organic compounds (VOCs), and soot/particulates [Adgate et al., 2014].

O\&NG VOC emissions are a complex mixture of hydrocarbons. Some of the VOCs identified have the potential to affect the human endocrine system [Colborn et al., 2014a]. Enhanced levels of VOCs have been observed in air near O\&NG wells, including the known human carcinogen benzene [Verma et al., 2000; Macey et al., 2014; Sovacool, 2014; Halliday et al., 2016]. Human health risk assessment based on 
measured and modeled VOC concentrations near O\&G sites indicate increased risks for respiratory, neuorological, and hematological health effects, as well as excess lifetime cancer risk above the U.S. EPA's de minimis risk of one in a million for people living nearest to the O\&NG sites [McKenzie et al., 2012; McKenzie et al., 2018; McMullin et al., 2018; Holder et al., 2019]. Associations between proximity to O\&NG sites and several health effects, including congenital heart defects, childhood leukemia, asthma, low birth weight, and preterm births have been reported [HEI, 2019]. In Colorado, children with congenital heart defects and leukemia are more likely to be born or living in the areas with the densest O\&NG activity [McKenzie et al., 2014; McKenzie et al., 2017; McKenzie et al., 2019]. While these studies indicate that VOC emissions from O\&NG activities have the potential to and may be affecting the health of nearby residents, further study will be necessary to elucidate causality [HEI, 2019].

Furthermore, atmospheric oxidation of O\&NG VOCs emissions contribute to the photochemical formation of ozone and secondary aerosols, which pose additional health concerns. A recent EPA study estimated 1000 and 970 added premature deaths from particulates (PM2.5) and ozone exposure caused by O\&NG pollutants in the U.S. by 2025, with 37 (from PM2.5) and 34 (from ozone) of those predicted to occur in Colorado [Fann et al., 2018]. Polluted air from the NCFR can be lofted during upslope flow conditions on the eastern Rocky Mountain slopes to high elevation where it can impact alpine ecosystems, including Rocky Mountain National Park [Brodin et al., 2010; Thompson et al., 2015; Benedict et al., 2018]. Up to $\approx 20 \mathrm{ppb}$ of additional ozone in air transport associated with O\&NG emission has been measured at the Rocky Mountain National Park Longs Peak monitoring station [Benedict et al., 2019]. For southwestern Colorado, including Mesa Verde National Park, an ozone enhancement of $9.6 \mathrm{ppb}$ was estimated for the ozone medium daytime 8-hour average ozone (MDA8) from O\&NG influences [Rodriguez et al., 2009].

Increased surface ozone, at times exceeding health safety standards, have been observed in the NCFR for some 20 years. After 10 years of repeated exceedances of the $75 \mathrm{ppb}$ U.S. ozone National Ambient Air Quality Standard (NAAQS), the Denver Metro Area (DMA) and NCFR, including the seven counties of Adams, Arapahoe, Boulder, Broomfield, Douglas, and Denver, as well as portions of Weld and Larimer counties, were designated as a 'Marginal' ozone nonattainment area (NAA) for the 2008 NAAQS. Because of a lack of progress in lowering ambient ozone, the area was bumped up from a "Marginal" to a "Moderate" NAA for the 2008 ozone standard in early 2016 [CDPHE, 2019a], and in August 2019 the EPA proposed to reclassify the area to a "Serious" NAA for the 2008 standard [EPA, 2019]. In consideration of new health exposure findings, the NAAQS was lowered from 75 to $70 \mathrm{ppb}$ in 2015 to provide a stronger protection to communities. This lower threshold will make it even more challenging for the NCFR to reach compliance with the standard.

In December 2018, the Colorado Department of Public Health and Environment (CDPHE) petitioned to the EPA for deferral of the re-designation (Supplemental Materials). In their letter, the agency stated that "Colorado has seen a dramatic decline in ambient levels of oil and gas related VOCs" and that the "majority of ozone concentrations in the DMNFR (Denver Metro Northern Front Range) are the result of emissions outside of the State's control, including naturally occurring emissions and emissions transported from other states and countries". The arguments presented in the letter did not consider most of the considerable body of peer-reviewed literature on Colorado's air quality and the influence of O\&NG industry that has emerged during the past 10 years. Shortly after the new Colorado governor, Jared Polis took office in 2019, he withdrew this petition, stating "There's too much smog in our air, and instead of hiding behind bureaucracy and paperwork that delay action, we are moving forward to make our air cleaner now," [Post, 2019]. For directing this policy there is urgency to consider the current un- 
derstanding of ozone precursor sources, atmospheric transport, and chemistry, from published literature. This article examines predominantly this peer-reviewed literature with the goal to provide the State agencies, boards, legislators and other policymakers a summary document for better assessing the role of O\&NG industry emissions on NCFR-DMA air quality, with a particular emphasis on surface ozone.

\section{Resources Utilized and Published Work}

This review and policy bridge provides an overview of the evolution of the understanding of atmospheric impacts and the current state of knowledge of O\&NG emissions in Colorado. A comprehensive review and evaluation of health effects of atmospheric O\&NG emissions in Colorado is intentionally not included. This review primarily builds on peer-reviewed journal articles. Included were all articles that were identified using various search strategies, regardless of the reputation of the journal or recognition of the published work by the community. There has been remarkable growth of literature over the past ten years (Figure 1). A good fraction of publications have arisen from the FRAPPE (Front Range Air Pollution and Photocchemistry Experiment [FRAPPE, 2013]) and DISCOVER AQ (Deriving Information on Surface Conditions from COlumn and VERtically Resolved Observations Relevant to Air Quality [DISCOVER$A Q, 2013])$ campaigns that, in the summer of 2014, brought researchers from a wide array of disciplines and institutes to Colorado to study air pollution sources and chemistry in the NCFR. Outcomes of these studies are evident in the increase in published papers in subsequent years (Figure 1). Most research on O\&NG impacts on air quality has centered in the NCFR, except a few studies that investigated methane emissions in the Four Corners region. This review will focus on the NCFR research. A summary of published work arranged by publication year is provided in Table 1.

It is noteworthy that the majority of this work has been published in high impact factor peer-reviewed science journals. Lead and contributing authors are from federal laboratories (i.e. NCAR, NOAA) and Colorado and out-of-state universities. The journal count is led by the Journal of Geophysical Research (18), followed by seven publications each in Atmospheric Chemistry and Physics, and five articles each in Environmental Science and Technology and Elementa. This publication record can be deemed as a testimony of the recognized importance of this research, having attracted leading scientists from top U.S. research institutions.
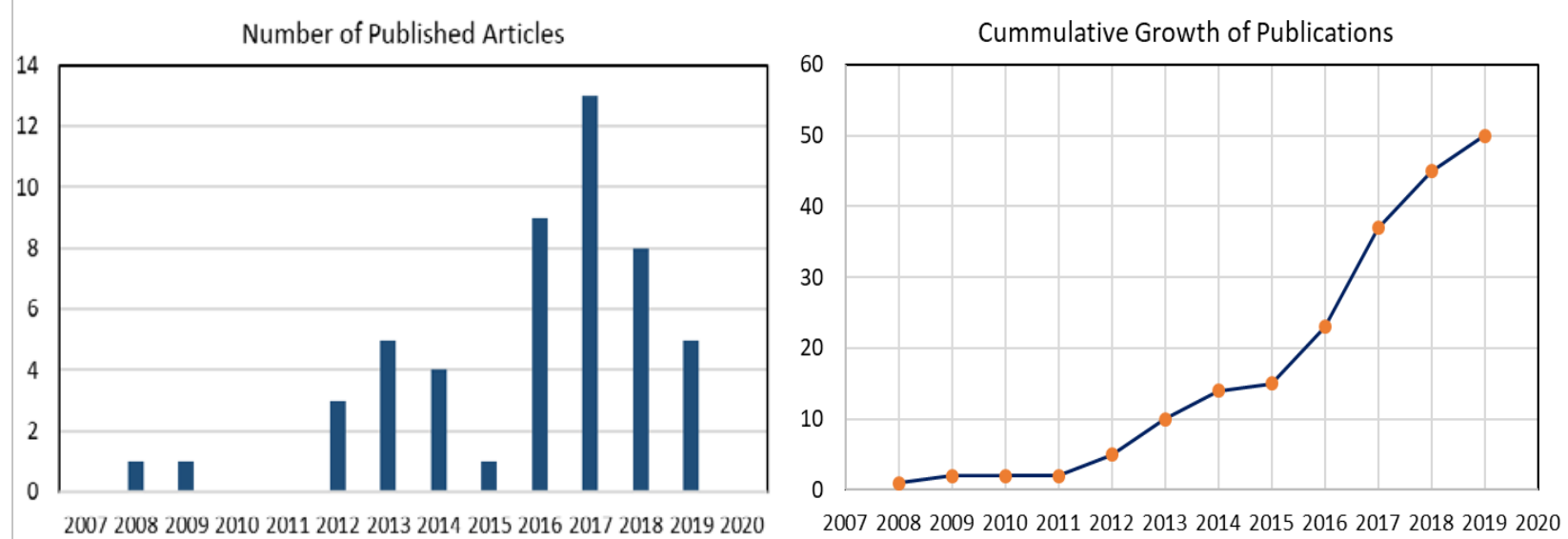

Figure 1. Growth of number of publications addressing air quality effects from O\&NG development in Colorado. The 2019 number is the count to September 30, 2019. 
Table 1: Summary of published literature addressing O\&NG influences on air quality in Colorado.

\begin{tabular}{|c|c|c|c|c|c|c|c|c|c|c|}
\hline Year & Authors & Lead Author Affiliation & Title & Journal & $\begin{array}{l}\text { Peer- } \\
\text { Review }\end{array}$ & Methane & vocs & Ozone & Other & Main Findings* \\
\hline 2008 & Not specified & $\begin{array}{l}\text { Colorado Department of } \\
\text { Publich Health and } \\
\text { Environment (CDPHE) }\end{array}$ & $\begin{array}{l}\text { Denver Metropolitan Area and North } \\
\text { Front Range 8-Hour Ozone State } \\
\text { Implementation Plan }\end{array}$ & $\begin{array}{l}\text { State of Colorado } \\
\text { Ozone } \\
\text { Implementation } \\
\text { Plan }\end{array}$ & & & & $x$ & & $\begin{array}{l}\text { Transport from cool pool area of the Platte Valley in } \\
\text { Weld County results in a mean daily maximum 8- } \\
\text { hour ozone of } 71 \mathrm{ppb} \text { at the four Front Range } \\
\text { monitors considered. }\end{array}$ \\
\hline 2009 & Rodriguez et al. & Colorado State Univ. & $\begin{array}{l}\text { Regional impacts of oil and gas } \\
\text { development on ozone formation in the } \\
\text { western United States }\end{array}$ & JAWMA & $\mathrm{x}$ & & & $\mathrm{x}$ & $\begin{array}{l}\text { Chemical and } \\
\text { transport } \\
\text { modeling }\end{array}$ & $\begin{array}{l}\text { A maximum 8MDA ozone enhancement of } 9.6 \mathrm{ppb} \\
\text { was estaimated from O\&NG emissions in } \\
\text { southwestern Colorado. }\end{array}$ \\
\hline 2012 & Mckenzie et al. & $\begin{array}{l}\text { Colorado School of Public } \\
\text { Health }\end{array}$ & $\begin{array}{l}\text { Human health risk assessment of air } \\
\text { emissions from development of } \\
\text { unconventional natural gas resources }\end{array}$ & Sci. Tot. Environ. & $x$ & & $\mathrm{x}$ & & $\begin{array}{l}\text { Health risk } \\
\text { assessment }\end{array}$ & $\begin{array}{l}\text { Median concentrations of benzene, ethylbenzene, } \\
\text { toluene, and m-xylene/p-xlyene were } 2.7,4.5,4.3, \\
\text { and } 9 \text { times higher in the well completion samples } \\
\text { than in the natural gas development samples, } \\
\text { respectively. }\end{array}$ \\
\hline 2012 & Petron et al. & NOAA/CIRES & $\begin{array}{l}\text { Hydrocarbon emissions characterization } \\
\text { in the Colorado Front Range: A pilot } \\
\text { study }\end{array}$ & J. Geophys. Res. & $x$ & $x$ & $x$ & & & $\begin{array}{l}\text { Emissions of methane and light NMHC VOC are most } \\
\text { likely underestimated in current inventories. }\end{array}$ \\
\hline 2012 & Levi & $\begin{array}{l}\text { Council on Foreign } \\
\text { Relations }\end{array}$ & $\begin{array}{l}\text { Comment on "Hydrocarbon emissions } \\
\text { characterization in the Colorado Front } \\
\text { Range: A pilot study" by Pétron et al. }\end{array}$ & J. Geophys. Res. & $\mathrm{x}$ & $x$ & & & & $\begin{array}{l}\text { Consideration of previously unconsidered } \\
\text { observations results in a new methane flux } \\
\text { estimates that are consistent with current } \\
\text { inventories but inconsistent with the estimates in } \\
\text { Pétron et al. (2012). }\end{array}$ \\
\hline 2013 & Petron et al. & NOAA/CIRES & $\begin{array}{l}\text { Reply to comment on "Hydrocarbon } \\
\text { emissions characterization in the } \\
\text { Colorado Front Range-A pilot study" by } \\
\text { M.A. Levi }\end{array}$ & J. Geophys. Res. & $x$ & $\mathrm{x}$ & $\mathrm{x}$ & & & $\begin{array}{l}\text { Flashing emission and regulatory modeled } \\
\text { composition profiles for a limited number of } \\
\text { condensate tanks probably do not represent the true } \\
\text { range of these parameters for the thousands of such }\end{array}$ \\
\hline 2013 & Gilman et al. & NOAA/CIRES & $\begin{array}{l}\text { Source signature of volatile organic } \\
\text { compounds from oil and natural gas } \\
\text { operations in northeastern Colorado }\end{array}$ & $\begin{array}{l}\text { Environ. Sci. } \\
\text { Technol. }\end{array}$ & $x$ & & $x$ & $\mathrm{x}$ & & $\begin{array}{l}\text { On average } 55 \pm 18 \% \text { of the } \mathrm{VOC}-\mathrm{OH} \text { reactivity was } \\
\text { attributable to emissions from O\&NG operations } \\
\text { indicating that these emissions are a significant } \\
\text { source of ozone precursors. }\end{array}$ \\
\hline 2013 & Swarthout et al. & Univ. of New Hampshire & $\begin{array}{l}\text { Volatile organic compound distributions } \\
\text { during the NACHT campaign at the } \\
\text { Boulder Atmospheric Observatory: } \\
\text { Influence of urban and natural gas }\end{array}$ & J. Geophys. Res. & $\mathrm{x}$ & & $\mathrm{x}$ & $x$ & & $\begin{array}{l}\text { Natural gas associated emissions have the potential } \\
\text { to impact downwind air quality as natural } \\
\text { gas NMHCs comprised } \approx 24 \% \text { of the calculated } \mathrm{OH} \\
\text { reactivity. }\end{array}$ \\
\hline 2013 & Brown et al. & NOAA/CIRES & $\begin{array}{l}\text { Nitrogen, Aerosol Composition, and } \\
\text { Halogens on a Tall Tower (NACHTT): } \\
\text { Overview of a wintertime air chemistry } \\
\text { field study in the front range urban } \\
\text { corridor of Colorado }\end{array}$ & J. Geophys. Res. & $x$ & & $\mathrm{x}$ & & $\begin{array}{l}\text { Halogens, NOx, } \\
\text { NOy, aerosol }\end{array}$ & $\begin{array}{l}\text { Large observed mixing ratios of light alkanes, both in } \\
\text { near-surface air and aloft, were attributable to local } \\
\text { emissions from oil and gas activities. }\end{array}$ \\
\hline
\end{tabular}


Table 1 (continued)

\begin{tabular}{|c|c|c|c|c|c|c|c|c|c|c|}
\hline Year & Authors & Lead Author Affiliation & Title & Journal & $\begin{array}{l}\text { Peer- } \\
\text { Review }\end{array}$ & Methane & vocs & Ozone & Other & Main Findings* \\
\hline 2013 & LaFranchi et al. & $\begin{array}{l}\text { Lawrence Livermore } \\
\text { National Laboratory }\end{array}$ & $\begin{array}{l}\text { Constraints on emissions of carbon } \\
\text { monoxide, methane, and a suite of } \\
\text { hydrocarbons in the Colorado Front } \\
\text { Range using observations of }{ }^{14} \mathrm{CO}_{2}\end{array}$ & Atmos. Chem. Phys. & $\mathrm{x}$ & $\mathrm{x}$ & $\mathrm{x}$ & & $\mathrm{CO},{ }^{14} \mathrm{CO}_{2}$ & $\begin{array}{l}\text { Enhanced concentrations of } \mathrm{CH}_{4} \text { and } \mathrm{C}_{3}-\mathrm{C}_{5} \text { alkanes } \\
\text { were found in air influenced by emissions to the } \\
\text { north and east of the } \mathrm{BAO} \text { and were suggested to } \\
\text { have been sourced from oil and gas fields located to } \\
\text { the northeast. }\end{array}$ \\
\hline 2014 & Petron et al. & NOAA/CIRES & $\begin{array}{l}\text { A new look at methane and } \\
\text { nonmethane hydrocarbon emissions } \\
\text { from oil and natural gas operations in } \\
\text { the Colorado Denver-Julesburg Basin }\end{array}$ & J. Geophys. Res. & $\mathrm{x}$ & $\mathrm{x}$ & $\mathrm{x}$ & & & $\begin{array}{l}\text { Emission of methane, VOC, and benzene in the DJB } \\
\text { were estimated to be } 3 \text { times, at least a factor of } 2 \text {, } \\
\text { and } 7 \text { times, respectively, larger than EPA and State } \\
\text { inventories. }\end{array}$ \\
\hline 2014 & Kort et al. & Univ. of Michigan & $\begin{array}{l}\text { Four corners: The largest US methane } \\
\text { anomaly viewed from space }\end{array}$ & Geophys. Res. Let. & $\mathrm{x}$ & $\mathrm{x}$ & & & & $\begin{array}{l}\text { Spaceborne remote sensing indicated large } \mathrm{CH}_{4} \\
\text { levels over the Four Corners region. Estimted } \\
\text { emissions largely exceeded inventory estimates. }\end{array}$ \\
\hline 2014 & Thompson et al. & Univ. of Colorado & $\begin{array}{l}\text { Influence of oil and gas emissions on } \\
\text { ambient atmospheric non-methane } \\
\text { hydrocarbons in residential areas of } \\
\text { Northeastern Colorado }\end{array}$ & Elementa & $\mathrm{x}$ & & $\mathrm{x}$ & & & $\begin{array}{l}\text { At residences near oil and gas operations, mean } \\
\text { mole fractions of the } C 2-C 5 \text { alkanes are enhanced by } \\
\text { a factor of } 18-77 \text { relative to the regional background, } \\
\text { and present at higher levels than typically found in } \\
\text { large urban centers. }\end{array}$ \\
\hline 2014 & Colburn et al. & $\begin{array}{l}\text { The Endocrine Disruption } \\
\text { Exchange }\end{array}$ & $\begin{array}{l}\text { An exploratory study of air quality near } \\
\text { natural gas operations }\end{array}$ & $\begin{array}{l}\text { Human \& Ecol. Risk } \\
\text { Assess. }\end{array}$ & $\mathrm{x}$ & & $\mathrm{x}$ & & $\begin{array}{l}\text { Health risk } \\
\text { assessment }\end{array}$ & $\begin{array}{l}\text { The number of NMHCs and their concentrations } \\
\text { were highest during the initial drilling phase and did } \\
\text { not increase during hydraulic fracturing in a closed- } \\
\text { loop system. }\end{array}$ \\
\hline 2015 & Richter et al. & Univ. of Colorado & $\begin{array}{l}\text { Compact highly sensitive multi-species } \\
\text { airborne mid-IR spectrometer }\end{array}$ & Applied Physics & $\mathrm{x}$ & & $\mathrm{x}$ & & Formaldehyde & $\begin{array}{l}\text { Ethane was enhanced at least ten times above } \\
\text { background levels in the DJB boundary layer. } \\
\text { Regions with elevated ethane overlapped with } \\
\text { elevated formaldehyde. }\end{array}$ \\
\hline 2016 & $\begin{array}{l}\text { Townsend-Small } \\
\text { et al. }\end{array}$ & Univ. of Cincinnati & $\begin{array}{l}\text { Using stable isotopes of hydrogen to } \\
\text { quantify biogenicand thermogenic } \\
\text { atmospheric methane sources: A case } \\
\text { study from the Colorado Front Range }\end{array}$ & Geophys. Res. Let. & $\mathrm{x}$ & $x$ & & & & $\begin{array}{l}\text { At least } 50 \% \text { of } \mathrm{CH}_{4} \text { emitted in the NCFR region is } \\
\text { biogenic. }\end{array}$ \\
\hline 2016 & Franco et al. & Univ. of Liege, Belgium & $\begin{array}{l}\text { Evaluating ethane and methane } \\
\text { emissions associated with the } \\
\text { development of oil and natural gas } \\
\text { extraction in North America }\end{array}$ & Environ. Res. Let. & $\mathrm{x}$ & & $\mathrm{x}$ & & & $\begin{array}{l}\text { Between 2009-2015, FTRl ethane column } \\
\text { observations over Boulder show a } 5.0 \% \text { per year rate } \\
\text { of increase. }\end{array}$ \\
\hline 2016 & Sullivan et al. & NASA Goddart & $\begin{array}{l}\text { Quantifying the contribution of } \\
\text { thermally driven recirculation to a high- } \\
\text { ozone event along the Colorado Front } \\
\text { Range using lidar }\end{array}$ & J. Geophys. Res. & $\mathrm{x}$ & & & $\mathrm{x}$ & Air recirculation & $\begin{array}{l}\text { Complex meteorology in this region can significantly } \\
\text { exacerbate pollution levels. A high summer } 2014 \\
\text { surface ozone pollution event was associated with } \\
\text { thermally driven upslope flow. }\end{array}$ \\
\hline
\end{tabular}




\begin{tabular}{|c|c|c|c|c|c|c|c|c|c|c|}
\hline Year & Authors & Lead Author Affiliation & Title & Journal & $\begin{array}{l}\text { Peer- } \\
\text { Review }\end{array}$ & Methane & vocs & Ozone & Other & Main Findings* \\
\hline 2016 & Reddy and Pfister & NCAR & $\begin{array}{l}\text { Meteorological factors contributing to } \\
\text { the interannual variability of } \\
\text { midsummer surface ozone in Colorado, } \\
\text { Utah, and other western U.S. states }\end{array}$ & J. Geophys. Res. & $\mathrm{x}$ & & & $x$ & $\begin{array}{l}\text { Reanalysis of } \\
\text { meteorology and } \\
\text { regional } \\
\text { chemistry } \\
\text { modeling }\end{array}$ & $\begin{array}{l}\text { Significant correlations were found between July } \\
\mathrm{MDA} \mathrm{O}_{3} \text { and meteorological variables. Increased } \\
500 \mathrm{hPa} \text { heights lead to high July } \mathrm{O}_{3} \text { particularly in } \\
\text { areas of elevated terrain near urban sources of } \mathrm{NO}_{2} \\
\text { and other } \mathrm{O}_{3} \text { precursors. }\end{array}$ \\
\hline 2016 & Vu et al. & $\begin{array}{l}\text { Univ. of California } \\
\text { Riverside }\end{array}$ & $\begin{array}{l}\text { Impacts of the Denver Cyclone on } \\
\text { regional air quality and aerosol } \\
\text { formation in the Colorado Front Range } \\
\text { during FRAPPE } 2014\end{array}$ & Atmos. Chem. Phys. & $\mathrm{x}$ & & $\mathrm{x}$ & $\mathrm{x}$ & $\begin{array}{l}\text { PAN, } \mathrm{CO}, \mathrm{NH}_{3} \text {, } \\
\text { aerosol } \\
\text { properties }\end{array}$ & $\begin{array}{l}\text { Meteorological patterns associated with the Denver } \\
\text { Cyclone increased pollutant levels, including aerosol } \\
\text { loadings in the Denver metropolitan area. Cyclone } \\
\text { conditions promote transport of aerosol constituents } \\
\text { from the northern Front Range into the Denver } \\
\text { metropolitan area, increasing aerosol mass loadings } \\
\text { and reducing visibilitv. }\end{array}$ \\
\hline 2016 & Halliday et al. & Pennsylvania State Univ. & $\begin{array}{l}\text { Atmospheric benzene observations } \\
\text { from oil and gas production in the } \\
\text { Denver-Julesburg Basin in July and } \\
\text { August } 2014\end{array}$ & J. Geophys. Res. & $\mathrm{x}$ & & $\mathrm{x}$ & & & $\begin{array}{l}\text { Unexpectedly high benzene mixing ratios were } \\
\text { observed at a site near Platteville AO (maximum of } \\
29.3 \text { ppbv), primarily at night, and assoicated to } \\
\text { emissions from nearby O\&NG operations. }\end{array}$ \\
\hline 2016 & Frankenberg et al. & $\begin{array}{l}\text { California Institute of } \\
\text { Technology }\end{array}$ & $\begin{array}{l}\text { Airborne methane remote } \\
\text { measurements reveal heavytail flux } \\
\text { distribution in Four Corners region }\end{array}$ & PNAS & $\mathrm{x}$ & $x$ & & & & $\begin{array}{l}\text { In the Four Corners Region, methane sources include } \\
\text { gas processing facilities, storage tanks, pipeline } \\
\text { leaks, and well pads, and a coal mine; emissions } \\
\text { ranged from } 2 \mathrm{~kg} \mathrm{~h}^{-1} \text { through } \quad 5,000 \mathrm{~kg} \mathrm{~h}^{-1} \text {. }\end{array}$ \\
\hline 2016 & Dingle et al. & $\begin{array}{l}\text { Univ. of California } \\
\text { Riverside }\end{array}$ & $\begin{array}{l}\text { Aerosol optical extinction during the } \\
\text { Front Range Air Pollution and } \\
\text { Photochemistry Éxperiment (FRAPPÉ) } \\
2014 \text { summertime field } \\
\text { campaign, Colorado, USA }\end{array}$ & Atmos. Chem. Phys. & $x$ & & $\mathrm{x}$ & & Aerosol & $\begin{array}{l}\text { The light extinction coefficient ext best correlated } \\
\text { with organic aerosols in the } O \& N G \text { emissions and } \\
\text { best correlated with nitrate aerosols under the } \\
\text { O\&NG and agriculture } \\
\text { influences. }\end{array}$ \\
\hline 2016 & McDuffie et al. & NOAA/CIRES & $\begin{array}{l}\text { Influence of oil and gas emissions on } \\
\text { summertime ozone in the Colorado } \\
\text { Northern Front Range }\end{array}$ & J. Geophys. Res. & $\mathrm{x}$ & & $x$ & $\mathrm{x}$ & & $\begin{array}{l}\text { O\&NG alkanes contribute over } 80 \% \text { to the observed } \\
\text { carbon mixing ratio, roughly } 50 \% \text { to the regional VOC } \\
\text { OH reactivity, and approximately } 20 \% \text { to regional } \\
\text { photochemical } \mathrm{O}_{3} \text { production }\end{array}$ \\
\hline 2017 & Tzompa-Sosa et al. & Colorado State Univ. & $\begin{array}{l}\text { Revisiting global fossil fuel and biofuel } \\
\text { emissions of ethane }\end{array}$ & J. Geophys. Res. & $\mathrm{x}$ & & $\mathrm{x}$ & $\mathrm{x}$ & & $\begin{array}{l}\text { Over northeastern Colorado year } 2001 \text { ethane } \\
\text { inventory emissions had to be increased by more } \\
\text { than } 40 \% \text { for modeled atmospheric mixing ratios to } \\
\text { match observations. }\end{array}$ \\
\hline 2017 & Evans and Helmig & Univ. of Colorado & $\begin{array}{l}\text { Investigation of the influence of } \\
\text { transport from oil and natural gas } \\
\text { regions on elevated ozone levels in the } \\
\text { northern Colorado Front Range }\end{array}$ & JAWMA & $\mathrm{x}$ & & & $x$ & & $\begin{array}{l}\text { Transport from areas with O\&NG operations } \\
\text { accounted for on the order of } 65 \% \text { of } 1 \text {-hr averaged } \\
\text { elevated ozone levels at BAO and South Boulder, } \\
\text { while the Denver urban corridor accounted for } 9 \% \text {. }\end{array}$ \\
\hline
\end{tabular}


Table 1 (continued)

\begin{tabular}{|c|c|c|c|c|c|c|c|c|c|c|}
\hline Year & Authors & Lead Author Affiliation & Title & Journal & $\begin{array}{c}\text { Peer- } \\
\text { Review }\end{array}$ & Methane & vocs & Ozone & Other & Main Findings* \\
\hline 2017 & Abeleira et al. & Colorado State Univ. & $\begin{array}{l}\text { Source characterization of volatile } \\
\text { organic compounds in the Colorado } \\
\text { Northern Front Range metropolitan area } \\
\text { during spring and summer } 2015\end{array}$ & J. Geophys. Res. & $\mathrm{x}$ & & $\mathrm{x}$ & $\mathrm{x}$ & & $\begin{array}{l}\text { The NCFR is more strongly influenced by ONG } \\
\text { sources of VOCs than other urban and suburban } \\
\text { regions in the U.S. }\end{array}$ \\
\hline 2017 & Cheadle et al. & CIRES/NOAA & $\begin{array}{l}\text { Surface ozone in the Colorado northern } \\
\text { Front Range and the influence of oil and } \\
\text { gas development during } \\
\text { FRAPPE/DISCOVER-AQ in summer } 2014\end{array}$ & Elementa & $\mathrm{x}$ & & $\mathrm{x}$ & $\mathrm{x}$ & $\mathrm{NO}_{\mathrm{x}}$ & $\begin{array}{l}\text { Correlation analyses in case studies showed that oil } \\
\text { and gas related activities are a } \mathrm{NO}_{x} \text { and } \mathrm{O}_{3} \text { precursor } \\
\text { source. }\end{array}$ \\
\hline 2017 & Pfister et al. & $\begin{array}{l}\text { National Center for } \\
\text { Atmospheric Research } \\
\text { (NCAR) }\end{array}$ & $\begin{array}{l}\text { Process-Based and Regional Source } \\
\text { Impact Analysis for FRAPPÉ and } \\
\text { DISCOVER-AQ } 2014\end{array}$ & $\begin{array}{l}\text { Final Report to } \\
\text { CDPHE }\end{array}$ & & & $\mathrm{x}$ & $\mathrm{x}$ & $\mathrm{NO}_{x}$ & $\begin{array}{l}\text { Mobile sources and oil and gas related emissions are } \\
\text { the largest contributors to local ozone production in } \\
\text { the NFRMA. }\end{array}$ \\
\hline 2017 & Baier et al. & Pennsylvania State Univ. & $\begin{array}{l}\text { Higher measured than modeled ozone } \\
\text { production at increased } \mathrm{NO}_{\mathrm{x}} \text { levels in the } \\
\text { Colorado Front Range }\end{array}$ & Atmos. Chem. Phys. & $\mathrm{x}$ & & $\mathrm{x}$ & $\mathrm{x}$ & $\begin{array}{l}\text { Ozone } \\
\text { production rate }\end{array}$ & $\begin{array}{l}\text { Ozone production rates peak during late morning. } \\
\text { Rates predicted by three models were lower than } \\
\text { direct observations. }\end{array}$ \\
\hline 2017 & $\begin{array}{l}\text { Abeleira and } \\
\text { Farmer }\end{array}$ & Colorado State Univ. & $\begin{array}{l}\text { Summer ozone in the northern Front } \\
\text { Range metropolitan area: } \\
\text { weekend-weekday effects, } \\
\text { temperature dependences, and the } \\
\text { impact of drought }\end{array}$ & Atmos. Chem. Phys. & $\mathrm{x}$ & & $x$ & $\mathrm{x}$ & $\mathrm{NO}_{x}$ & $\begin{array}{l}\text { Ozone in the NCFR area was either stagnant or } \\
\text { increasing between } 2000 \text { and } 2015 \text {, likely because of } \\
\text { decreasing NOx emissions in a NOx -saturated } \\
\text { environment and increased anthropogenic VOC } \\
\text { emissions. }\end{array}$ \\
\hline 2017 & Robertson et al. & Univ. of Wyoming & $\begin{array}{l}\text { Variation in methane emission rates } \\
\text { from well pads in four oil and gas basins } \\
\text { with contrasting production volumes } \\
\text { and compositions }\end{array}$ & $\begin{array}{l}\text { Environ. Sci. } \\
\text { Technol. }\end{array}$ & $\mathrm{x}$ & $\mathrm{x}$ & & & & $\begin{array}{l}\text { In the DJB, } 70 \% \text { of total methane emissions were } \\
\text { from } 20 \% \text { of the well pads The total mass of } \\
\text { methane emitted as a percent of gross methane } \\
\text { produced was } 2.1 \%(1.1-3.9 \%)\end{array}$ \\
\hline 2017 & Kaser et al. & NCAR & $\begin{array}{l}\text { The effect of entrainment through } \\
\text { atmospheric boundary layer growth on } \\
\text { observed and modeled surface ozone in } \\
\text { the Colorado Front Range }\end{array}$ & J. Geophys. Res. & $\mathrm{x}$ & & & $\mathrm{x}$ & $\begin{array}{l}\text { Boundary layer } \\
\text { growth, } \\
\text { contribution of } \\
\text { entrainment and } \\
\text { synoptic } \\
\text { transport to } \mathrm{O}_{3}\end{array}$ & $\begin{array}{l}\text { A large day-to-day variability of ozone above the } \\
\text { atmospheric boundaray layer was attributed to } \\
\text { differing air mass origins. On average, morning } \\
\text { boundary layer growth contributes } 4.8 \mathrm{ppb} \mathrm{hr}^{-1} \text { to the } \\
\text { morning hour ozone increase. }\end{array}$ \\
\hline 2017 & Pfister et al. & NCAR & $\begin{array}{l}\text { Using observations and source specific } \\
\text { model tracers to characterize pollutant } \\
\text { transport during FRAPPÉ and DISCOVER- } \\
\text { AQ }\end{array}$ & J. Geophys. Res. & $\mathrm{x}$ & & & & $\begin{array}{l}\text { Air flow } \\
\text { characteriza-tion }\end{array}$ & $\begin{array}{l}\text { During upslope events, frequently, there is a } \\
\text { separation of air masses that are heavily influenced } \\
\text { by oil and gas emissions to the north and dominated } \\
\text { by urban emissions to the south. NCFR pollution can } \\
\text { "spillover" into the valleys to the west of the } \\
\text { Continental Divide. }\end{array}$ \\
\hline
\end{tabular}




\section{Table 1 (continued)}

\begin{tabular}{|c|c|c|c|c|c|c|c|c|c|c|}
\hline Year & Authors & Lead Author Affiliation & Title & Journal & $\begin{array}{l}\text { Peer- } \\
\text { Review }\end{array}$ & Methane & vocs & Ozone & Other & Main Findings* \\
\hline 2017 & Yacovitch et al. & Aerodyne Research Inc. & $\begin{array}{l}\text { Natural gas facility methane emissions: } \\
\text { measurements by tracer flux ratio in two } \\
\text { US natural gas producing basins }\end{array}$ & Elementa & $\mathrm{x}$ & $\mathrm{x}$ & & & & $\begin{array}{l}\text { Methane emission rates from DJB gathering stations } \\
\left(\mathrm{kg} \mathrm{CH}_{4} \mathrm{hr}^{-1}\right) \text { were lower compared to results from } \\
\text { other basins. }\end{array}$ \\
\hline 2017 & Zaragoza et al. & Colorado State Univ. & $\begin{array}{l}\text { Observations of acyl peroxy nitrates } \\
\text { during the Front Range Air Pollution and } \\
\text { Photochemistry Experiment (FRAPPE) }\end{array}$ & J. Geophys. Res. & $\mathrm{x}$ & & $\mathrm{x}$ & $\mathrm{x}$ & PAN, PPN & $\begin{array}{l}\text { Anthropogenic VOCs played a dominant role in PAN } \\
\text { production during periods with high } \mathrm{O}_{3} \text {. The } \\
\text { contribution of biogenic VOCs to local } \mathrm{O}_{3} \text { production } \\
\text { was relatively small. }\end{array}$ \\
\hline 2017 & Smith et al. & Univ. of Michigan & $\begin{array}{l}\text { Airborne quantification of methane } \\
\text { emissions over the Four Corners Region }\end{array}$ & $\begin{array}{l}\text { Environ. Sci. } \\
\text { Technol. }\end{array}$ & $x$ & $\mathrm{x}$ & & & & $\begin{array}{l}\text { Using five independent days of measurements an } \\
\text { average regional } \mathrm{CH}_{4} \text { flux of } 0.54 \pm 0.20 \mathrm{Tg} \mathrm{yr}^{-1} \text { was } \\
\text { calulated, in close agreement with a space-based } \\
\text { estimate made for 2003-2009. }\end{array}$ \\
\hline 2018 & Bien and Helmig & Univ. of Colorado & $\begin{array}{l}\text { Changes in summertime ozone in } \\
\text { Colorado during 2000-2015 }\end{array}$ & Elementa & $x$ & & & $\mathrm{x}$ & & $\begin{array}{l}\text { Median and upper percentile surface } O 3 \text { in the DMA } \\
\text { has not declined at the rates seen in other western } \\
\text { U.S. regions. }\end{array}$ \\
\hline 2018 & Mckenzie et al. & Univ. of Colorado & $\begin{array}{l}\text { Ambient nonmethane hydrocarbon } \\
\text { levels along Colorado's Northern Front } \\
\text { Range: Acute and chronic health risks }\end{array}$ & $\begin{array}{l}\text { Environ. Sci. } \\
\text { Technol. }\end{array}$ & $x$ & & $\mathrm{x}$ & & & $\begin{array}{l}\text { O\&NG air pollutant concentrations increased with } \\
\text { proximity to an } O \& G \text { facility, as did health risks. }\end{array}$ \\
\hline 2018 & Peischl et al. & $\begin{array}{l}\text { NOAA/CIRES/Univ. of } \\
\text { Colorado }\end{array}$ & $\begin{array}{l}\text { Quantifying methane and ethane } \\
\text { emissions to the atmosphere from } \\
\text { Central and Western U.S. oil and natural } \\
\text { gas production regions }\end{array}$ & J. Geophys. Res. & $\mathrm{x}$ & $\mathrm{x}$ & $x$ & & & $\begin{array}{l}\text { The } \mathrm{CH}_{4} \text { and } \mathrm{C}_{2} \mathrm{H}_{6} \text { emissions attributed to O\&NG } \\
\text { operations in the Denver Basin region also remained } \\
\text { statistically unchanged between } 2008 \text { and March } \\
2015 \text {. }\end{array}$ \\
\hline 2018 & Fann et al. & $\begin{array}{l}\text { US EPA Research Triangle } \\
\text { Park }\end{array}$ & $\begin{array}{l}\text { Assessing human health PM2.5 and } \\
\text { ozone impacts from U.S. oil and natural } \\
\text { gas sector emissions in } 2025\end{array}$ & $\begin{array}{l}\text { Environ. Sci. } \\
\text { Technol. }\end{array}$ & $\mathrm{x}$ & & $x$ & $x$ & PM2.5 & $\begin{array}{l}\text { Under current growth projections oil and natural gas } \\
\text { emissions are predicted to increase summer } 8 \text {-hour } \\
\text { ozone by } 6-8 \mathrm{ppb} \text {. }\end{array}$ \\
\hline 2018 & McMullin et al. & $\begin{array}{l}\text { Colorado Department of } \\
\text { Public Health and } \\
\text { Environment }\end{array}$ & $\begin{array}{l}\text { Exposures and health risks from volatile } \\
\text { organic compounds in communities } \\
\text { located near oil and gas exploration and } \\
\text { production activities in Colorado (U.S.A.) }\end{array}$ & $\begin{array}{l}\text { Int. J. Environ. Res. } \\
\text { \& Public Health }\end{array}$ & $x$ & & $\mathrm{x}$ & & Health effects & $\begin{array}{l}56 \text { VOCs emitted from OG operations in Colorado } \\
\text { were identified. Further characterization of primary } \\
\text { and secondary VOCs emitted from OG sites during } \\
\text { different phases of operations is needed to address } \\
\text { the community health relevance. }\end{array}$ \\
\hline 2018 & Benedict et al. & Colorado State Univ. & $\begin{array}{l}\text { Impact of Front Range sources on } \\
\text { reactive nitrogen concentrations and } \\
\text { deposition in Rocky Mountain National } \\
\text { Park }\end{array}$ & PeerJ & $x$ & & $\mathrm{x}$ & & $\begin{array}{l}\mathrm{NO}_{x} \mathrm{NO}_{y} \\
\text { ammonia }\end{array}$ & $\begin{array}{l}\text { Elevated concentrations of reactive nitrogen were } \\
\text { associated with emissions from oil and gas } \\
\text { operations, which are frequently co-located with } \\
\text { agricultural production and livestock feeding areas in } \\
\text { the region, and from urban areas. }\end{array}$ \\
\hline
\end{tabular}


Table 1 (continued)

\begin{tabular}{|c|c|c|c|c|c|c|c|c|c|c|}
\hline Year & Authors & Lead Author Affiliation & Title & Journal & $\begin{array}{l}\text { Peer- } \\
\text { Review }\end{array}$ & Methane & vocs & Ozone & Other & Main Findings* \\
\hline 2018 & $\begin{array}{l}\text { Abdi-Oskouei et } \\
\text { al. }\end{array}$ & Univ. of lowa & $\begin{array}{l}\text { Impacts of physical parameterization on } \\
\text { prediction of ethane concentrations for } \\
\text { oil and gas emissions in WRF-Chem }\end{array}$ & Atmos. Chem. Phys. & $\mathrm{x}$ & & $\mathrm{x}$ & & $\begin{array}{l}\text { EPA emission } \\
\text { inventory }\end{array}$ & $\begin{array}{l}\text { Comparison between airborne measurements and } \\
\text { WRF-Chem model simulations indicated a low bias } \\
\text { of ethane in regions close to O\&NG activities, } \\
\text { suggesting underestimation of O\&NG emissions in } \\
\text { the NEI-2011. }\end{array}$ \\
\hline 2018 & Bahreini et al. & $\begin{array}{l}\text { Univ. of California } \\
\text { Riverside }\end{array}$ & $\begin{array}{l}\text { Sources and characteristics of } \\
\text { summertime organic aerosol in the } \\
\text { Colorado Front Range: perspective from } \\
\text { measurements and WRF-Chem } \\
\text { modeling }\end{array}$ & Atmos. Chem. Phys. & $\mathrm{x}$ & & & & $\begin{array}{l}\text { Aerosol } \\
\text { characteriza-tion }\end{array}$ & $\begin{array}{l}\text { It was estimated that the O\&NG sector contributed } \\
\text { to }<5 \% \text { of total organic aerosol, but up to } 38 \% \text { of } \\
\text { anthropogenic seccondary organic aerosol in the } \\
\text { region due to O\&NG VOC emissions. }\end{array}$ \\
\hline 2019 & Oltmans et al. & NOAA & $\begin{array}{l}\text { Boundary layer ozone in the Northern } \\
\text { Colorado Front Range in July-August } \\
2014 \text { during FRAPPE and DISCOVER-AQ } \\
\text { from vertical profile measurements }\end{array}$ & Elementa & $\mathrm{x}$ & & & $\mathrm{x}$ & & $\begin{array}{l}\text { The association of high } \mathrm{O}_{3} \text { days at } \mathrm{BAO} \text { with transport } \\
\text { from O\&NG sectors suggested that O\&NG emissions } \\
\text { were an important source of } \mathrm{O}_{3} \text { precursors and are } \\
\text { crucial in producing peak } \mathrm{O}_{3} \text { events. Exposure of } \\
\text { populations in the Foothills area is not captured by } \\
\text { the current regulatory network, and likely } \\
\text { underestimated. }\end{array}$ \\
\hline 2019 & Tsompa-Soza et al. & Colorado State Univ. & $\begin{array}{l}\text { Atmospheric implications of large C2-C5 } \\
\text { alkane emissions from the U.S. oil and } \\
\text { gas industry }\end{array}$ & J. Geophys. Res. & $\mathrm{x}$ & & $\mathrm{x}$ & & & $\begin{array}{l}\text { Of four regions analyzed, Boulder showed the } \\
\text { highest percentage contribution from the oil and gas } \\
\text { sector to total abundances of C2-C5 alkanes } \\
\text { throughout the troposphere. }\end{array}$ \\
\hline 2019 & Lindaas et al. & Colorado State Univ. & $\begin{array}{l}\text { Acyl peroxy nitrates link oil and natural } \\
\text { gas emissions to high ozone abundances } \\
\text { in the Colorado Front Range during } \\
\text { summer } 2015\end{array}$ & J. Geophys. Res. & $\mathrm{x}$ & $\mathrm{x}$ & $\mathrm{x}$ & $\mathrm{x}$ & $\begin{array}{l}\text { Alky nitrates, } \\
\text { photochemical } \\
\text { modeling }\end{array}$ & $\begin{array}{l}\text { Anthropogenic } V O C \text { precursors dominated APN } \\
\text { production when } \mathrm{O}_{3} \text { was most elevated in the NCFR } \\
\text { in summer } 2015 \text {. Propane and } n \text {-pentane, primarily } \\
\text { from O\&NG emissions, drive elevated PPN/PAN } \\
\text { ratios during high } \mathrm{O}_{3} \text { events. Emissions from the } \\
\mathrm{O} \& \mathrm{NG} \text { sector contribute to } \mathrm{O}_{3} \text { production on high } \mathrm{O}_{3}\end{array}$ \\
\hline 2019 & Kille et al. & Univ. of Colorado & $\begin{array}{l}\text { Separation of methane emissions from } \\
\text { agricultural and natural gas sources in } \\
\text { the Colorado Front Range }\end{array}$ & Geophys. Res. Let. & $x$ & $x$ & $\mathrm{x}$ & & Ammonia & $\begin{array}{l}\text { Natural gas methane sources dominate over } \\
\text { agricultural and other sources, but the latter are } \\
\text { relatively more important when excess } \mathrm{CH}_{4} \text { is }\end{array}$ \\
\hline 2019 & Benedict et al. & Colorado State Univ. & $\begin{array}{l}\text { Volatile organic compounds and ozone } \\
\text { in Rocky Mountain National Park during } \\
\text { FRAPPÉ }\end{array}$ & Atmos. Chem. Phys. & $\mathrm{x}$ & & $\mathrm{x}$ & $\mathrm{x}$ & & $\begin{array}{l}\text { It was estimated that for that high ozone events } \\
\text { associated with O\&NG signatures, NCFR sources } \\
\text { contributed } \approx 20 \text { ppb of additional ozone. }\end{array}$ \\
\hline
\end{tabular}

167 Table references: [CDPHE, 2008; Rodriguez et al., 2009; Levi, 2012; McKenzie et al., 2012; Pétron et al., 2012; Brown et al., 2013; Gilman et al., 2013; LaFranchi et al., 2013; Pétron et al., 2013; Swarthout

168 et al., 2013; Colborn et al., 2014b; Kort et al., 2014; Petron et al., 2014; Thompson et al., 2014; Richter et al., 2015; Dingle et al., 2016; Franco et al., 2016; Frankenberg et al., 2016; Halliday et al., 2016;

169 McDuffie et al., 2016; Reddy and Pfister, 2016; Sullivan et al., 2016; Townsend-Small et al., 2016; Vu et al., 2016; Abeleira et al., 2017; Abeleira and Farmer, 2017; Cheadle et al., 2017; Evans and Helmig, 
2017; Kaser et al., 2017; Pfister et al., 2017a; Pfister et al., 2017b; Robertson et al., 2017; Smith et al., 2017; Tzompa-Sosa et al., 2017; Yacovitch et al., 2017; Zaragoza et al., 2017; Abdi-Oskouei et al.,

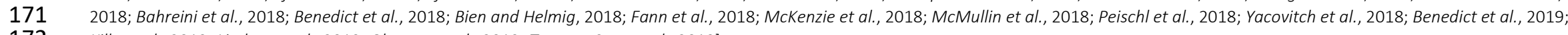

172 Kille et al., 2019; Lindaas et al., 2019; Oltmans et al., 2019; Tzompa-Sosa et al., 2019] 
174 Air quality monitoring and air sampling is conducted by the CDPHE, NOAA, the National Park Service, 175 Boulder County, and the City of Longmont. A map showing the distribution of monitoring sites and measured species is shown in Figure 2. Ozone is monitored th the highest number of sites, followed by PM2.5, and nitrogen oxides. There currently is only one location with continuous VOCs monitoring (Boulder Reservoir); however, two more sites are anticipated to begin VOCs monitoring within the next year (Longmont Union Reservoir and Rocky Flats North). Methane monitoring is currently conducted at the Boulder Reservoir and Longmont airport. Besides this real-time monitoring, methane and VOCs are also quantified in flasks and canisters samples collected at Niwot Ridge (NOAA) and at Platteville and downtown Denver (CAMPS) by CDPHE. There is a relatively high density of sites in the DMA, but a relatively sparse network within and along the periphery of the DJB O\&NG area.

\section{$184 \quad$ Nitrogen Oxides}

185 Nitrogen oxide ( $\mathrm{NO}$ and $\mathrm{NO}_{2}=\mathrm{NO}_{x}$ ) emissions associated with O\&NG development arise from a number of sources, including flaring, on-site electrical power generation, heavy equipment operation at fracking sites, and the heavy truck traffic for moving equipment and fluids in and out of O\&NG well sites. Other sources are compressor stations, and heavy tanker truck traffic for transporting produced oil and gas products from the site. $\mathrm{NO}_{\mathrm{x}}$ emissions arising from these sources have been studied in a number of O\&NG basins [Bogacki and Macuda, 2014; Field et al., 2014; Majid et al., 2017; Archibald et al., 2018]. However, this literature review did not identify any studies from the DJB, leaving their emissions contribution uncertain. The Regional Air Quality Council emissions inventory lists the year 2017 total O\&NG $\mathrm{NO}_{x}$ sources at 65.8 tons per day, which is a 59\% increase over the year 2011 emissions [Brimmer, 2019].

\section{Methane}

Methane is emitted by a variety of sources, with wetlands, landfills, feedlots, seepage from geological reservoirs, and O\&NG extraction, distribution, and industries being the most significant ones on a global scale. Methane is a potent greenhouse gas. The methane background in the global atmosphere has more than doubled since preindustrial [Kirschke et al., 2013]. The increase of methane from anthropogenic sources is the second ranked contribution $\left(\right.$ after $\left.\mathrm{CO}_{2}\right)$ to radiative forcing from anthropogenic greenhouse gases. The oxidation of methane in the atmosphere is also a pathway for ozone production, which constitutes another climate forcing pathway and exerts stress on the natural and agricultural ecosystems and human and animal life (see below). A reduction of global methane emission by $20 \%$ would reduce the ozone MDA8 by $\approx 1$ ppb in the background atmosphere [West and Fiore, 2005; West et al., 2006]. The benefits of methane reductions are shared internationally. The $20 \%$ emissions reduction was estimated to avoid $\approx 30,000$ premature deaths by 2030 globally [West et al., 2006].

The O\&NG industry is the single most significant source of methane in Colorado [Pétron et al., 2012]. Quantifying the methane flux from the O\&NG industry has been challenging as the geographic area of the O\&NG activities overlaps with agricultural, beef, and dairy production areas, which all constitute significant methane sources. Methane to non-methane hydrocarbon (NMHC) relationships, in particular those with ethane and propane, and the stable isotopic signature of methane, have been used to decipher the O\&NG contribution to the total methane flux. Point source measurements near emission sources, mobile lab ground surveying, and aircraft observations, in combination with inventory information, have been used to derive basin-wide O\&NG methane flux estimates. Three NOAA studies, covering the observations during three short time windows within the 2008-2015 period, are summarized in 

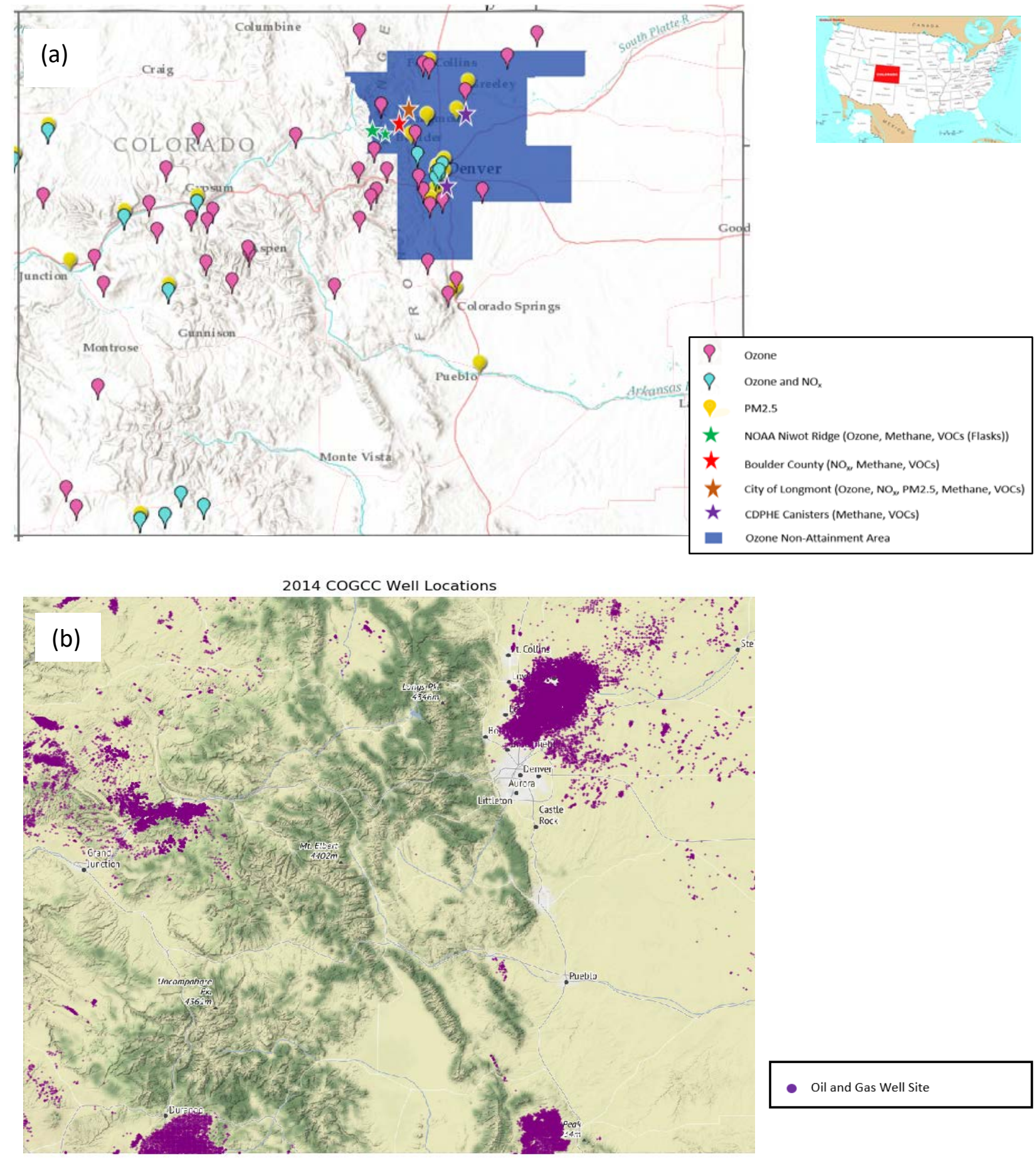

Figure 2: (a) Air monitoring sites in Colorado that report ozone, nitrogen oxides, and PM2.5 data to the EPA Air Quality System archive (map downloaded from https://www.epa.gov/outdoor-air-quality-data/interactive-mapair-quality-monitors). Additional sites operated by NOAA and regional municipalities, and sites that monitor methane and VOCs were added to the map. (b) Distribution of oil and gas well sites (purple dots) for the same map area within the State of Colorado (map downloaded from https://cogcc.state.co.us/\#/home). 
Table 2. Data in this table are scaled to annual flux estimates. As all these experiments relied on relatively short observation periods, there is an inherent uncertainty from the lack of knowledge if, and how representative these shorter observations were for year-round conditions. Further, variability in parameterizations and uncertainties in assumptions that go into these flux estimates cause relatively large uncertainty ranges in the results (column 3 ). The best estimate values of the three studies are relatively consistent, nonetheless, spanning 130-169 Gg yr-1. According to the U.S. Energy Information Administration, Colorado households consume an average of 103 million BTU of natural gas per year [EIA, 2009], which converts to $\approx 2$ tons of household natural gas consumption per year. Therefore, the Peischl et al. [2018] O\&NG methane emissions estimate corresponds to the natural gas consumed by $\approx 84,000$ Colorado households.

These data points are too few, and uncertainties are too large, to make statements about potential trends in the methane flux over this time window with statistical certainty. Considering the increase in natural gas production during this time period, the relatively flat total emissions would indicate a reduction in the relative fugitive emissions rate. Peischl et al. [2018] present a statistical analysis that results in an 83\% likelihood of a reduced methane leakage rate during 2008-2015.

Methane emissions result in atmospheric concentration increases in the source regions and downwind. Due to the relatively long atmospheric lifetime of methane ( $\approx 9$ years) in comparison to NMHCs, at $\approx$ $1900 \mathrm{ppb}$ the methane background is 3-4 orders of magnitudes higher, and methane enhancements are moderate $(\approx 10 \%)$ on a relative scale. The slow atmospheric oxidation of methane causes relatively little of the regionally emitted methane to be oxidized locally. Modelling work [Lindaas et al., 2019] estimated a $2 \%$ contribution from DJB-wide emitted methane oxidation to the regional ozone production.

The Four Corners area is another Colorado region that has received attention because of its recognized methane emissions. Based on satellite data analyses, in 2014, Kort et al. [2014] reported “... the largest anomalous $\mathrm{CH}_{4}$ levels viewable from space over the conterminous U.S. are located at the Four Corners

Table 2. Basin-wide O\&NG methane flux estimates for the DJB.

\begin{tabular}{|c|c|c|c|}
\hline \multirow[t]{2}{*}{ Time Period } & \multicolumn{2}{|c|}{$\begin{array}{c}\text { Methane Flux } \\
\qquad \mathrm{Gg} \mathrm{yr}^{-1}\end{array}$} & \multirow[t]{2}{*}{ Reference } \\
\hline & mean & range & \\
\hline Summer 2008 & 130 & $72-252$ & Petron et al., 2012 \\
\hline $\begin{array}{l}\text { May 29, 2012; } \\
\text { May 31, } 2012\end{array}$ & 169 & $109-229$ & Petron et al., 2014 \\
\hline March 2015 & 158 & $88-228$ & Peischl et al., 2018 \\
\hline
\end{tabular}

250 region in the Southwest U.S." Their work primarily pointed out discrepancies between inventory and these satellite data derived methane flux estimates. Follow-up studies have confirmed an abundance of fossil methane sources in the Four Corners regions, with contribution from coal shaft venting, natural seepage, and O\&NG well and distribution sites [Frankenberg et al., 2016]. The methane flux estimate

251 for the Four Corners region of $540 \pm 200 \mathrm{Gg} \mathrm{yr}^{-1}(1 \sigma)$ [Smith et al., 2017] exceeds the methane O\&NG 252 flux estimates for the DJB by a factor of $\approx 3$.

\section{Volatile Organic Compounds}

254 Petroleum NMHC are the dominant constituents of VOC emissions from O\&NG sources. Atmospheric 255 VOCs in the DJB are highly elevated, largely due to O\&NG emissions. NMHC and the combined atmos256 pheric carbon from all species exceeds those in major urban areas [Swarthout et al., 2013]. Relative 257 abundances of VOC species scale inversely with molecular size; ethane is typically the NMHC emitted at 258 the highest flux, followed by propane, then the butanes, and so forth. There are dozens of individual 
VOCs that have been listed in O\&NG emissions. However, the bulk of the mass is contributed by a narrower count. For instance, in O\&NG plumes identified in continuous monitoring at the Boulder Reservoir, the 16 most abundant VOC species account for approximately $90 \%$ of the total O\&NG emitted VOC mass (Helmig et al., manuscript in preparation). O\&NG VOC emissions also contain aromatic constituents, such as the BTEX species (benzene, toluene, ethylbenzene, xylenes) [Pétron et al., 2012; Gilman et al., 2013; Swarthout et al., 2013; Koss et al., 2017]. While these are relatively low, sub-1\% constituents, they have received notable attention because of their recognized health impacts on humans.

Over the past five years, ethane has become an increasingly utilized tracer for natural gas VOC emissions. This increased attention to ethane has also been fostered by new instrumentation that has recently become available for sensitive and fast response ethane detection [Richter et al., 2015; Yacovitch et al., 2015; Yacovitch et al., 2017; Barkley et al., 2019; Kostinek et al., 2019]. Ethane has relatively weak non-O\&NG source emissions, which makes it a sensitive tracer for identifying O\&NG plumes and influences. The ethane to methane enhancement ratio has been used to characterize emissions from particular basins, and for scaling the VOCs flux to methane. In the DJB, natural gas on average has an ethane/methane molar ratio of $12-16 \%$ (ppb/ppb), equivalent to a $23-30 \%$ mass ratio [Peischl et al., 2018; Kille et al., 2019][Helmig et al., manuscript in preparation], which is very close to the estimated mean of all U.S. O\&NG basin emissions [Helmig et al., 2016].

Atmospheric monitoring data show highly variable VOC concentrations. Large VOC enhancements can occur in air plumes originating from O\&NG source regions [Swarthout et al., 2013; Rossabi et al., 2017][Helmig et al., in prep.]. This effect is also evident in the large relative standard deviation of statistical analyses of the region's VOCs data [Rossabi et al., 2019]. At the Boulder Atmospheric Observatory (BAO), located in Erie at the transition between the more densely populated and industrialized DMA to the south, and the DJB O\&NG and agricultural areas to the north, air composition was also found to have variable urban and O\&NG signatures from significant mixing and recirculation of air influenced by these different sources [McDuffie et al., 2016]. As with any surface-emitted source, VOC concentrations also vary significantly between day and night, with typically higher nighttime concentrations due to the nighttime absence of dilution of surface air from convective mixing [Swarthout et al., 2013; Halliday et al., 2016]. Concentrations drop with height [Swarthout et al., 2013], indicating that releases occur at the surface. Several studies have demonstrated spatial gradients with increasing mean VOC concentrations and increasing variability with decreasing distance to O\&NG wells and operations. Total alkanes concentrations increased by a factor of 10 from distances $>1600 \mathrm{~m}$ to distances of $<152 \mathrm{~m}$ [McKenzie et al., 291 2018]. Even higher gradients (up to a factor of $\approx 30$ ) were found for BTEX species. The significance of O\&NG sources to ambient BTEX was demonstrated in continuous surface measurements conducted at a site near Platteville during FRAPPE [Halliday et al., 2016]. Benzene values exceeding 10 ppb, with a maximum of $29.3 \mathrm{ppb}$, were observed on multiple occasions, particularly at night when emissions were trapped near the surface. The mean nighttime value $(0.73 \mathrm{ppb})$ for August 2014 was above the 1:100,000 increased lifetime cancer risk threshold $(0.5 \mathrm{ppb})$ listed by the World Health Organization [WHO, 2019]. Benzene values above $10 \mathrm{ppb}$ were also reported in nine canister samples collected from a mobile surface platform downwind of different O\&NG facilities, including operations labelled as "waste water disposal well" and "oil waste dumping facility" [Pfister et al., 2017a]. Newer observations from mobile platforms presented by NOAA and University of Wyoming scientists point to even larger BTEX enhancements downwind of drilling operations and produced wastewater facilities: Madronich et 
al. [2019] found an abundance of benzene mixing ratios in the 10-50 ppb range near Greeley in the center of Weld County. Mielke-Maday et al. [2019], in their analysis of correlating wind with benzene data, found the highest benzene enhancements when winds originated from the direction of a nearby multiwell pad. Thus far, the highest concentrations were recorded in proximity of oil and gas wastewater disposal facilities in eastern Weld County, with maximum BTEX plume values approaching 500 ppb downwind of these facilities [Edie et al., 2019].
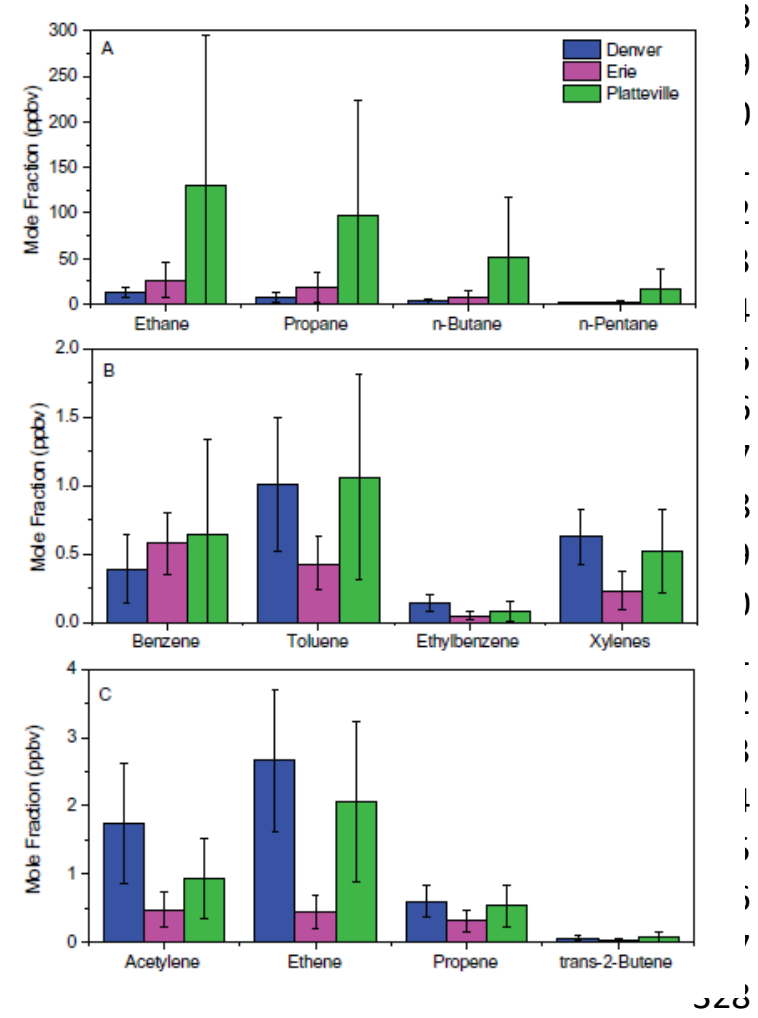

Figure 3: Statistical comparison of 2013 atmospheric monitoring data for twelve VOCs from downtown Denver, Erie, and Platteville [Thompson et al., 2014].
Horizontal gradients in VOCs have also been demonstrated on a larger regional scale along transects from the periphery towards the center of the DJB. This behavior has been seen in surface [Thompson et al., 2014; Helmig et al., 2015; Rossabi et al., 2017; Rossabi et al., 2019] and aircraft data [Richter et al., 2015]. A representative example is illustrated in Figure 3, comparing data from a site in downtown Denver, data from Erie (southern border of the DJB), and from Platteville, which is located in about the center of the DJB (Figure 4a). Mean mole fractions for the alkane NMHC are factors of 10-50 higher at Platteville than in Denver, with Erie values falling in between. The Platteville ethane and propane values are among the highest ambient concentration values for these species ever published in the literature. For higher molecular weight NMHC and aromatic compounds, spatial gradients are less pronounced, indicating that emission sources for these compounds have a more even geographical distribution. Besides health concerns from direct exposure, these emissions are a major culprit for the regional photochemical ozone production that will be discussed in the next section.

\section{Ozone}

Ozone has long been recognized as an important air pollutant. Breathing air with elevated ozone irritates the respiratory system and can cause acute and chronic respiratory cardiovascular health effects. People with asthma, children, and the elderly are particularly at increased risk. There is a rich literature on ozone health effects (i.e. [Fleming et al., 2018; Lefohn et al., 2018]). The risk increases with ozone concentration and length of exposure. Health effects have been noted in numerous studies below the current 70 ppb NAAQS [Fleming et al., 2018]. Exposure of communities to elevated ozone has been proven to increase mortality rates during and shortly after increased ozone events [Gryparis et al., 2004; Bell et al., 2005]. In an extensive study across 90 U.S. urban communities, a $0.5 \%$ increase in daily mortality was found for a $10 \mathrm{ppb}$ increase in daily mean ozone [Bell et al., 2005]. 


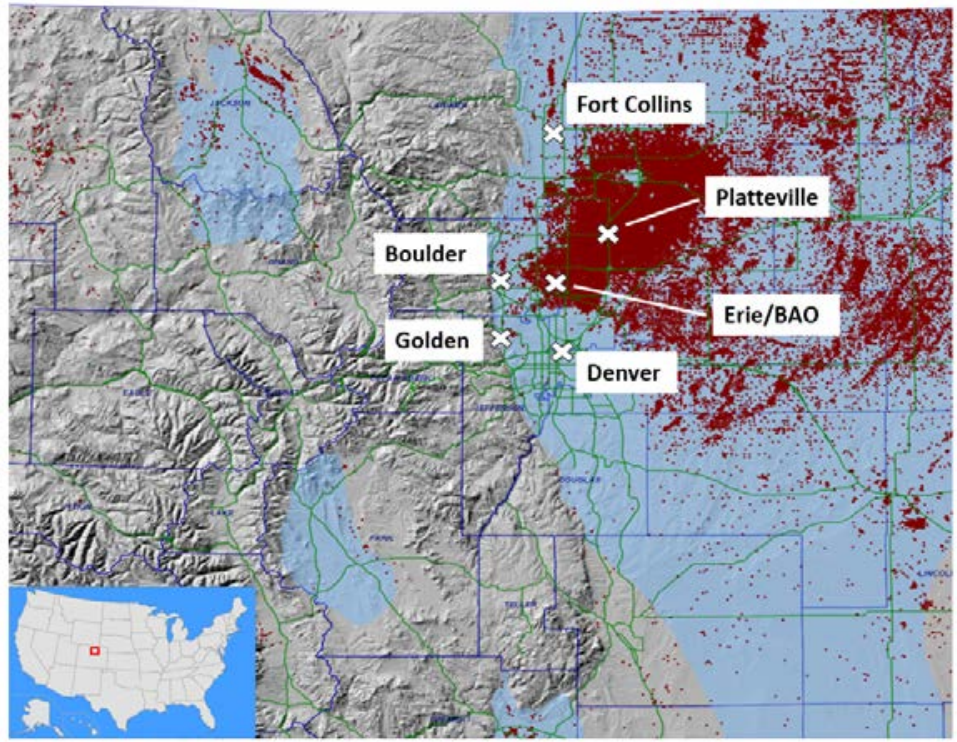

(a)

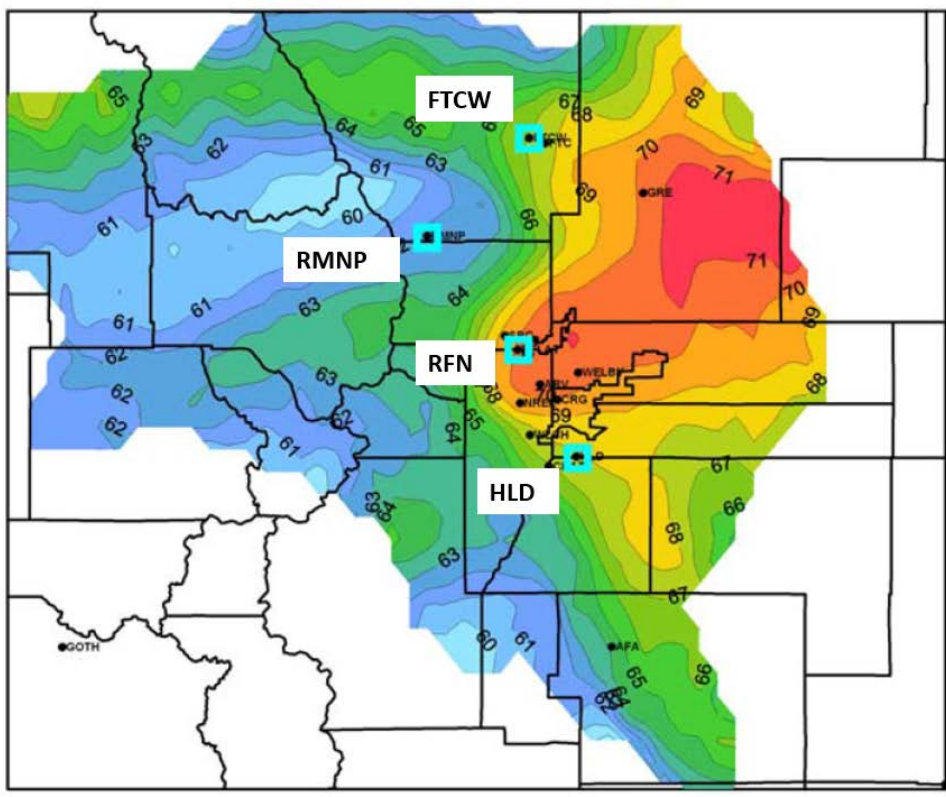

(b)

Figure 4: Comparison of geographical distribution of O\&NG well locations with elevated ozone source region. (a) The Colorado Northern Front Range with major urban cities Fort Collins, Boulder, and Denver, as well as the study sites Erie/BAO and Platteville that are mentioned in the text. Active oil and gas wells are indicated by red dots (map from by Colorado Oil and Gas Conservation Commission website,

https://cogcc.state.co.us/\#/home). The map area matches the geographical area depicted in (b). The inset in the bottom left corner shows as a red rectangular the approximate location of the map area within the State of Colorado. (b) Source footprint analysis for elevated ozone measured at the four indicated monitoring sites. This figure is a reproduction of Figure 3-13 from the DMA and North Front Range 8-Hour Ozone State Implementation Plan [CDPHE, 2008]. The color contours are the results of a correlation analysis of ozone measured at the four surface size with HYSPLIT back trajectories. The contours display “ ... the mean May 17 - August 15, 2006, Front Range daily maximum 8-hour ozone concentrations resulting from transport from given source areas. These are the average concentrations that result at these four monitors when an air mass originates in a given area." [CDPHE, 2008]. The four ozone monitoring locations (squares) are Fort Collins West FTCW), Rocky Mountain National Park (RMNP), Rocky Flats North (RFN), and Highland (HLD). 
Through plant respiration and surface uptake, ozone is also damaging to vegetation [Mills et al., 2018]. The stress on vegetation from ozone reduces plant growth and productivity, causing significant loss to U.S. and global farming industry and food supply [Van Dingenen et al., 2009; Lapina et al., 2016].

Ozone is not a directly emitted pollutant, but is formed in the atmosphere through a series of photochemical reactions that are fueled by emission of $\mathrm{VOCs}$ and $\mathrm{NO}_{\mathrm{x}}$ in the presence of sunlight. The efficiency of this chemistry is rather complex, depending on other variables, including the ratio of $\mathrm{VOC} / \mathrm{NO}_{\mathrm{x}}$, VOC speciation and reactivity, solar radiation, temperature, wind speed and dispersion conditions. This causes rates of ozone production to vary substantially, from single digits to tens of $\mathrm{ppb} \mathrm{h}^{-1}$ during midday hours.

Background ozone is generally higher in the western U.S. overall than in the eastern U.S. [Zhang et al., 2011; Cooper et al., 2012; Jaffe et al., 2018], causing air moving into the NCFR being on average higher in ozone than in many other parts of the country. An analysis by the U.S. EPA estimates the non-U.S. background contribution on days when ozone is relatively high (>60 ppb) at $38 \mathrm{ppb}$, which is the highest among 12 included comparison sites [EPA, 2008], and more than half of the current ozone NAAQS. Contributions from other U.S. states, as well as from neighboring countries and trans-Pacific transport, can further add to this background [Dunker et al., 2017; Lin et al., 2017]. The contribution of ozone from long-range transport is on average contributing more to the background in spring than during the primary summer ozone season [Cooper et al., 2012; Lin et al., 2017]. During 2000-2015, the resulting summer ozone background (range of median ozone during summer at Colorado rural, non-mountain monitoring stations) was $32-49 \mathrm{ppb}$, with mean and median values of $41 \mathrm{ppb}$ ([Bien and Helmig, 2018]; Supplemental Materials). Downward folding of high troposphere/lower stratosphere air has been observed on a few occasions to bring elevated ozone do the surface. These conditions depend on the strength and location of the polar jet, are irregular, and have been reported exclusively for the spring [Langford et al., 2009; Lin et al., 2015]. Emissions from wildfires can contribute to ozone production, with the rate and total amount of ozone produced being sensitive to the fire and plume conditions [Jaffe and Wigder, 2012; Jaffe et al., 2013]. Overall, fire emissions are a minor contribution compared to the role of anthropogenic emissions to the larger geographic scale ozone buildup [Lin et al., 2017]. This influence is highly variable, and estimated to enhance the Intermountain West regional summer MDA8 by $0.3-1.5 \mathrm{ppb}$ [Lu et al., 2016]. Regional ozone production is further promoted by the dry and sunny climate. Combined, these conditions make it more challenging for western States, including the NCFR, to control its ozone as it leaves less room than in other regions for local ozone production to exceed the standard [Cooper et al., 2015]. Notably, background ozone at remote high elevations sites across the western U.S. during summer has been declining during the most recent decade [Bien and Helmig, 2018; Jaffe et al., 2018], which should constitute favorable conditions for the NCFR on its path towards lowering surface ozone.

A compelling case demonstrating the influence of O\&NG emissions on surface ozone in the NCFR was first published in the Denver Metropolitan Area and North Front Range 8-Hour Ozone State Implementation Plan in 2008 [CDPHE, 2008]. Combining summer ozone data from four sites along the NCFR with air transport back trajectory analyses showed that for elevated ozone events during mid-May to mid-August 2006, air transport from the center of the DJB was associated with the highest ozone values, whereas transport from surrounding areas, including the DMA, brought in air with lower ozone levels (Figure 4b). The geographical overlap of the source footprint with highest ozone with the area of highest O\&NG well density (Figure 4a), provided credence to the argument that O\&NG industry emissions played an important role in ozone production and high ozone occurrences. Daytime summer ozone production rates of $7-8 \mathrm{ppb} \mathrm{hr}{ }^{-1}$ have been seen in ambient diurnal ozone data [CDPHE, 2008; Cheadle et 
al., 2017]. Direct measurements of the ozone production capacity in Golden during FRAPPE found maximum late morning ozone production rates about two times that high [Baier et al., 2017]. Assessing the relative benefit of VOCs versus $\mathrm{NO}_{x}$ controls is extremely challenging in the NCFR. VOC/NOx ratios vary widely across the region, with lower ratios present in the DMA, and higher ratios in the VOC-rich DJB. These different air masses can mix during transport and recirculation, causing a wide range of spatial and temporal differing conditions and ozone production regimes.

Two studies estimated the contribution of O\&NG VOCs to the total reactivity with the $\mathrm{OH}$ radical using VOC speciation and atmospheric concentrations at the BAO. This variable can serve as a metric for the chemical reactivity of air and its potential for producing ozone. A NOAA study estimated that $55+/-18 \%$ of the reactivity was attributable to O\&NG emissions [Gilman et al., 2013]. Swarthout et al. [2013], using a similar approach but with independently collected data, determined a value of $57 \%$. While $\mathrm{OH}$ reactivity does not directly translate to ozone production, based on these results, both groups predicted that O\&NG VOC emissions would enhance and play a significant role in the regional ozone budget. It should be noted that these measurements were conducted in the late winter, when ozone production is relatively moderate in the NCFR. Therefore, these findings represent, for example, lower influence from 404 biogenic VOCs.

A NOAA study, i.e. McDuffie et al. [2016], went a step further and incorporated VOC speciation and VOCs reactivity in a photochemical model. Their findings showed "that O\&NG alkanes contribute over $80 \%$ to the observed carbon mixing ratio, roughly $50 \%$ to the regional $\mathrm{VOC} \mathrm{OH}$ reactivity, and approximately $20 \%$ to regional photochemical ozone production." Using observations from BAO for correlation analyses and modeling of oxidation chemistry, Lindaas et al. [2019] stipulated that O\&NG emissions contribute to ozone production on high ozone days; however, that study fell short of providing a quantitative estimate. Another modeling study by NCAR scientists [Pfister et al., 2017b], building on FRAPPE data for the wider NCFR area, concluded that on average, O\&NG emissions contribute $30-40 \%$ to the local ozone production on high ozone days. It needs to be emphasized that all of these studies derived estimates for the ozone produced regionally, not the total ozone, which is also determined by the background that is transported into the region (see above).

These predictions from reactivity consideration and modeling are backed by a series of observational studies: Evans et al. [2014], using a correlation analysis of ambient ozone and wind data from BAO and the South Boulder Creek regulatory monitor, found that during 2009-2012, 65\% (average between both sites) of elevated ozone events were associated with transport from O\&NG production regions. Cheadle et al. [2017], analyzing selected cases of observations near Greeley during FRAPPE, estimated that O\&NG emissions contributed up to $\approx 20 \mathrm{ppb}$ to ozone production on high ozone days. Oltmans et al. [2019] conducted an in depth analysis of the conditions on high ozone days at BAO. Their analysis showed an association of high ozone days with transport from sectors with intense O\&NG production towards the northeast. The authors concluded that O\&NG emissions were an important source of ozone precursors and are crucial in producing peak ozone events in the NCFR. The ozone production chemistry is primarily driven by VOCs of anthropogenic origin; biogenic emissions appear to have a minor contribution to the NCFR ozone production chemistry [Cheadle et al., 2017; Lindaas et al., 2019].

428 Ozone enhancements from O\&G emission transport have been measured all the way up the Rocky 429 Mountain National Park, in upslope flow along the eastern slopes of the Rocky Mountains. Benedict et 430 al. [2019] estimated that high ozone events associated with O\&NG emissions contributed $\approx 20 \mathrm{ppb}$ of 431 additional ozone at the Rocky Mountain National Park Longs Peak air monitoring station. This poses the 432 question of ecosystem impacts of the elevated ozone on the natural environment, including Rocky 
Mountain National Park. Ozone has long been known to damage crops, and reduce yields in agriculture [Heck et al., 1982; Van Dingenen et al., 2009; Avnery et al., 2011]. For sensitive crops, those losses can be well more than $10 \%$, accounting to a significant revenue loss to the farming industry [Morgan et al., 2003; Avnery et al., 2011]. The DJB O\&G production overlaps with a region that is also considered the agricultural heartland of Colorado. Colorado's agricultural industry provides over $\$ 40$ billion to the state economy [USDA, 2018]. There have been no assessments to date on the revenue loss to this industry from the elevated ozone caused by O\&NG emissions within the State.

\section{Particulates}

The DMA has a history of air quality problems from particulates pollution that goes back to the 1970s and 80s [Waggoner et al., 1983]. The episodic wintertime occurrences of reduced visibility from accumulation of gaseous and particulate matter near the surface have been named the 'Denver Brown Cloud' [Neff, 1997]. They are tied to the peculiar topographical and meteorological conditions in the NCFR, where during the winter shallow $(<500 \mathrm{~m}$ ) boundary layer heights, low convective mixing, also promoted by snow cover and cold soils, can promote accumulation and buildup of particular emissions over several days. A series of studies revealed a mix of sources, with traffic, urban, and agricultural emissions [Wolff et al., 1981]. Most of the visibility reduction was found to be associated to particulates smaller than $2.5 \mu \mathrm{m}$ [Groblicki et al., 1981]. Secondary aerosol production, particularly growth of organic aerosol, as air recirculates over areas with different source signatures, was identified as a major contributing mechanism for aerosol buildup [Sloane et al., 1991]. The secondary production of aerosol and ozone occurred on winter days, with temperatures as low as $6^{\circ} \mathrm{C}$ [Ferman et al., 1981].

Despite the population growth of the DMA/NCFR, occurrences of Denver Brown Cloud episodes and the aerosol loading (CDPHE, 2019, unpublished results) have seen a gradual decline during the past two decades, most likely thanks to stricter air pollution control measures.

O\&NG operations are sources of atmospheric aerosol in several ways. Heavy equipment operation, soot emissions from diesel engines and power generation, unloading and handling of silica that can be added as a fracking fluid constituent, and soot from oil and gas flaring, are some of the important primary emissions sources. There is also potential of secondary aerosol formation from the atmospheric oxidation of gaseous emissions, such as $\mathrm{H}_{2} \mathrm{~S}, \mathrm{SO}_{2}, \mathrm{NO}_{x}$, and VOCs. These gases are known to produce less volatile chemicals during their atmospheric oxidation, which can serve as aerosol nuclei or add to existing aerosol. Comparatively few published studies have addressed aerosol from O\&NG operations in Colorado. The reason may lie in the difficulty of attribution, which is more difficult for PM2.5 relative to ozone, whose formation mechanism is better defined.

Continuous vertical profiles of aerosol and gaseous components were measured during the NACHTT (Nitrogen, Aerosol Composition, and Halogens on a Tall Tower) campaign at the BAO [Brown et al., 2013]. The aerosol mass was dominated by nitrate, which was mostly from sources within the region. Other significant contributions were from organics and sulfate, with sulfate primarily being transported longrange. While the composition of organic gas phase compounds was noted to have a strong O\&NG influence, the study conclusions do not specify O\&NG influences on the aerosol composition. An investigation on aerosol dependency on circulation patterns in the NCFR found that cyclone conditions promoted the transport of aerosol constituents from the northern Front Range into the DMA, increasing aerosol mass loadings and reducing visibility [Vu et al., 2016]. The circulation pattern would be expected to cause air to become enriched in O\&NG emissions while passing over the DJB, before circling back into 
the DMA. The organic fraction made the largest component of total aerosol. The study, however, did not specify if the high organic aerosol loading was associated to O\&NG precursor emissions.

Two publications report aerosol studies on O\&NG contribution to the NCRF aerosol loading in the context of FRAPPE. Dingle et al. [2016] determined extinction enhancements relative to the amount of the combustion tracer carbon monoxide. They found an increase in the extinction coefficient with the aging of air masses that was accompanied by formation of secondary organic aerosol, and the extinction was strongest correlated with organic aerosol in O\&NG-influenced air, and with nitrate aerosol in O\&NG and agriculture emissions. Bahreini et al. [2018] reported a significant contribution of non-combustion organic aerosol. Organic aerosol was on average $40 \%$ higher in plumes with a high O\&NG influence, and the organic aerosol was dominated by secondary constituents, suggesting that they may be products of O\&NG VOCs oxidation. The study concluded that O\&NG sector emissions contribute up to $38 \%$ to the secondary organic aerosol in the region.

\section{Atmospheric Circulation Influences in the NCFR}

The impact of O\&NG emissions on NCFR air quality is exacerbated by very peculiar atmospheric circulation patterns. Johnson and Toth [1982] were the first ones to present an in depth characterization of the daily cycle of mountain-valley winds. At night, cooler air flows from the mountains and down the Platte River valley over the plains. During the day, as the mountains warm, the air flow reverses bringing air from over the plains (and source regions; east to westerly transport) back to the foothills. Such recycling can continue over several days. During daytime, upslope flow is a prominent flow regime. This circulation is driven by the warming of the easterly slopes of the Rocky Mountains range, causing convective uplifting that is pulling in air from the east. The flow reverses during the night, with cooler air from higher elevations descending the mountains and forcing west to east air transport.

Figure 5 is a partial reproduction of a figure from Evans and Helmig [2017]. These windroses, generated from summer data at BAO, show the very distinct diurnal flow behavior, with flows from north to southeasterly directions dominating during the daytime hours, and south to westerly winds predominant at night. The study authors analyzed wind data from eight locations along the NCFR. The average diurnal winds were remarkably consistent, demonstrating the importance of this flow regime for the wider NCFR. The transition time between these two flow regimes changes with distance from the mountain slopes, with locations further east experiencing an on average later onset of upslope flow conditions. The diurnal flow regimes are most pronounced during the summer because of the larger solar irradiance that is providing the thermal forcing.

The upslope flow paths are somewhat segregated, such that there is a separation of air masses that are heavily influenced by O\&NG emissions to the north of the DMA, whereas air masses south of North Denver are more strongly influenced by urban emissions [Pfister et al., 2017a]. Air enriched with emissions from urban, traffic, O\&NG, and other regional sources can get 'trapped' along the mountain slopes during late afternoon. This is reflected by highest ozone levels being observed at monitoring sites nearest to the mountain slopes [Bien and Helmig, 2018] and at the lower elevations in the foothills [Brodin et al., 2010]. In upslope flow, polluted air from the NCFR regularly reaches high elevation zones on the eastern side of the Rocky Mountain Continental Divide [Brodin et al., 2010; Benedict et al., 2019]. On days with particularly strong flow conditions, NCFR pollution can "spillover" into the valleys to the west of the Continental Divide [Pfister et al., 2017b].

Although a classical view of high pollution episodes invokes a stagnant high pressure region, usually over flat terrain, the meteorology of the NCFR leads to more complex circulation regimes. A common regime 


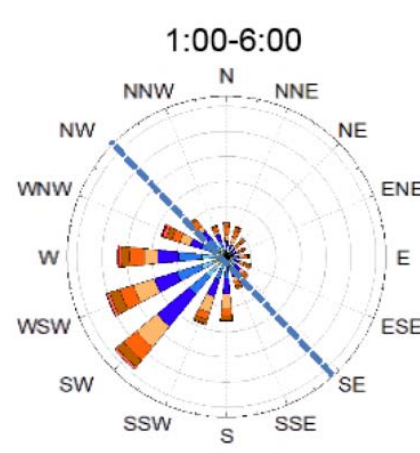

13:00-20:00

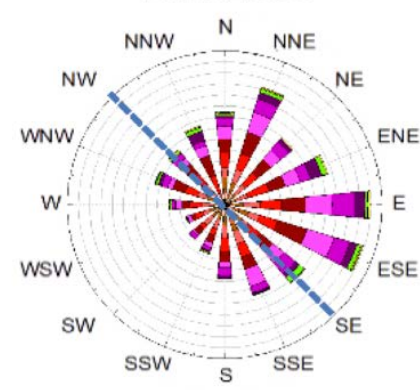

518

519

520

521

522

523

524

525

526

527

528

529

530

531

532

533

534

535

536

537

538

539

540

541

542 on ozone trends.

\section{Inventories}

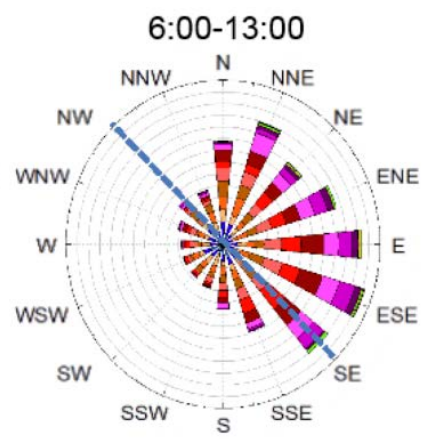

20:00-1:00

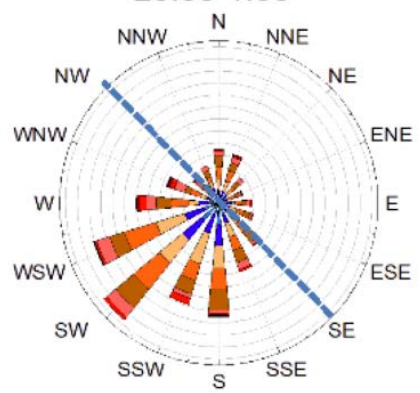

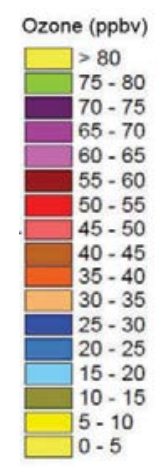

Figure 5: Polar histograms showing wind direction at BAO for the summer months (June 1 - August 31), broken up into four diurnal time windows (times are in MST) [Evans and Helmig, 2017]. Colors represent the ozone distribution within each sector according to the scale provided in the legend. The dotted line is an approximate illustration of the sectors with O\&NG activities (NW to SE), with the O\&NG sectors the ones located in the NNW - ESE portion of the wind roses.

in the winter occurs with downslope westerly warm winds from the Rocky Mountains flowing over colder air drawn from the east toward a low pressure trough along the foothills or due to lee-cyclogenesis located over southeast Colorado [Neff, 1997]. During the summer, the 'Denver Cyclone' is often observed. These conditions provide a similar opportunity for trapping pollutants near the surface [Wilczak and Glendening, 1988; Wilczak and Christian, 1990; Szoke, 1991]: In this case, the Denver Cyclone occurs nearer the surface with warmer air aloft from the south that originated over the Palmer Divide, a ridge extending to the east and south of Denver. As the air from the east (underlying the warmer air aloft) carries pollutants and precursors from the eastern plains, the air can stagnate as it encounters the topographic barrier to the west. This circulation pattern can cause pollution to circulate and accumulate for several days, leading to increases of secondary pollutants. Vu et al. [2016] demonstrate an up to an $80 \%$ increase in aerosol constituents during a cyclone episode during FRAPPE.

The frequency and prominence of high ozone occurrences is correlated with high pressure systems that promote high temperatures, stagnant air circulation, and sunny weather, conditions that combined are favorable for photochemical ozone production. Reddy and Pfister [2016] investigated this relationship and proposed a method in which monthly 500-mbar pressure heights were used for correcting the yearto-year variability in the fourth highest 8-hour ozone average. Further, these conditions promote cyclic terrain-driven circulations that reduce pollution transport away from sources. The authors recommend correcting annual MDA8 data using monthly 500-mbar pressure heights for reducing weather influences

Emission inventories have been developed by state and national regulatory agencies in support of air quality modeling and for directing policy development. These bottom-up inventories are based on emissions estimates of facility types and operations with regional/basin-wide scaling using best available fa- 
cility counts. Evaluation of the bottom-up inventory estimates has mostly been accomplished by university and NOAA scientists through comparing with top-down flux estimates that were developed from aircraft and surface data. Experimental capabilities for basin-wide, top-down flux determinations have improved remarkably over recent years. Emissions have been estimated by determining the enhancement in the basin outflow by aircraft profiling upwind and downwind of production regions, determination of horizontal winds and boundary layer depth [Karion et al., 2013; Karion et al., 2015; Peischl et al., 2015; Peischl et al., 2018].

Most of these studies have pointed out inconsistencies in inventories and a likely underestimation of O\&NG inventory surface emissions. Uncertainties of bottom-up inventories can arise from the extrapolation of limited information of facility-scale emissions from venting, flashing, and leakage, and the neglect of differences in practices of operators. Inventories are annual averages with little to no temporal information. [Vaughn et al., 2018] demonstrated that this may be part of inventory uncertainties and discrepancy between bottom-up and top-down emission estimates. Further, the lack of temporal information makes source apportionment and model performance evaluation more difficult.

In the most extensive evaluation of methane and VOC emissions representation in the Western Regional Air WRAP Phase III inventory [WRAP, 2009] to date, [Pétron et al., 2012] concluded that "there are notable inconsistencies between our results and state and national regulatory inventories". They further stated "Our analysis suggests that the emissions of the species we measured are most likely underestimated in current inventories and that the uncertainties attached to these estimates can be as high as a factor of two". Results also showed that methane sources from natural gas industries in Colorado were most likely underestimated by at least a factor of two. Besides methane and total VOC, the study also assessed benzene, and concluded that for this species State inventory estimates were too low by at least a factor of five. Levi [2012] commented on the difficulties and high sensitivity of the top-down emissions estimation based on emission ratios of VOC species.

In their assessment of the National Emissions Inventory (NEI) for 2010, Tzompa-Sosa et al. [2017] found that inventory fossil fuel emissions had to be increased by $40 \%$ for the Northern Hemisphere to yield agreement with observations, except for the central U.S., including Colorado, where even the $40 \%$ increase under-predicted observed mixing ratios in the lower troposphere.

Pfister et al. [2017a], in their modeling of FRAPPE and DISCOVER-AQ data, found that they had to increase O\&NG non-ethane emissions by a factor of four over their best inventory estimate for the best match between observations and model output.

The most recent evaluation, based on NOAA aircraft surveying [Peischl et al., 2018], illustrates relatively little improvement in agreement between inventories and top-down emission estimates. The NOAA study determined a DJB-wide ethane flux of $7.0+/-1.1 \times 10^{3} \mathrm{~kg} \mathrm{hr}^{-1}$, which translates to $61+/-10 \times 10^{6}$ $\mathrm{kg}$ (kilotonnes) per year. This ethane flux alone is higher than then current Regional Air Quality Council O\&NG non-ethane total VOC bottom-up inventory flux of $56 \times 10^{6} \mathrm{~kg} \mathrm{yr}^{-1}$ [Brimmer, 2019]. With ethane constituting approximately $30 \%$ of the total O\&NG VOC flux in the regional oil and gas emissions [Gilman et al., 2013; Swarthout et al., 2013], the Peischl et al. [2018] ethane flux equates to a total O\&NG VOC flux of $230 \times 10^{6} \mathrm{~kg} \mathrm{yr}^{-1}$. Excluding ethane yields $170 \times 10^{6} \mathrm{~kg} \mathrm{yr}^{-1}$, which exceeds the non-ethane RAQC total VOC estimate by at least a factor of three.

Taken together, these available comparison studies highlight the deviations between the bottom-up and top-town emissions estimates. Unfortunately, there is a scarcity of top-down estimates available for this evaluation, and each of these have relatively large uncertainty windows themselves. Nonetheless, 
these disagreements diminish the confidence in the State's bottom-up inventories, and air quality modeling that is building on these most likely under-predicted emissions.

\section{Changes in O\&NG Emissions and Atmospheric Concentrations}

Since 2008, Colorado has implemented regulations to reduce VOC emissions from O\&NG sources, and methane-specific regulations came into place in 2014 [Ogburn, 2014; CDPHE, 2019c]. State inventories largely build on projected emissions reductions from these measures. However, there are very few data records that allow an evaluation of the important questions, if and how actual O\&NG emissions in the DJB have changed over time. There is no published peer-review literature at this time that has addressed this question and presented trend results that would allow assessing basin-wide emission changes with statistically significant certainty. Data from after the methane emissions rule adoption in 2014 would be most helpful in understanding the benefits of that regulation and current emission levels.

Comparing historic with modern observations of VOC data from Boulder, Thompson et al. [2014] stated

"An initial look at comparisons with data sets from previous years reveals that ambient levels for oil and gas-related NMHC in Erie, as well as further downwind in Boulder, have not decreased, but appear to have been increasing, despite tightening of emissions standards for the oil and gas industries in 2008."

CDPHE has been conducting canister air sampling at Platteville since 2011 [CDPHE, 2019b]. However, inconsistencies in the sampling, uncertainties in the analysis protocols, siting of the sampling location, and the proximity of the sampling location to abundant nearby well sites make trend determinations and their interpretation for the wider region from these data uncertain.

Ethane column observations conducted from 2010-2015 at the NCAR Foothills Laboratory in Boulder are presented in [Franco et al., 2016]. Their best estimate is a rate of increase of $5.0 \%$ per year. This rate is above estimated rates for the increase of ethane in the Northern Hemisphere background atmosphere during this time window [Helmig et al., 2016], which implies a regional emissions increase. However, the uncertainty interval in this result is rather large. Including newer data, extending the record to 20102018, does not yield a trend in the atmospheric ethane abundance (J. Hannigan, NCAR, personal communication, April 2019).

NOAA conducted sampling of VOCs, with up to daily resolution, from 2008-2016 at $300 \mathrm{~m}$ height from the BAO tower. Data for the O\&NG VOC tracer propane collected during midday to afternoon hours, when boundary layer mixing is most progressed, do not show statistically significant changes, indicating stable total emissions of O\&NG VOCs during this 9-year time window [Oltmans et al., 2019]. Lastly, the methane flux estimates listed in Table 2, covering observations between 2008-2015, do not show any changes in the total methane flux that are outside of the uncertainty windows of the individual observations. Assuming that the VOC/methane ratio has remained constant, these methane flux determinations do not suggest changes in basin-wide VOC emissions. Considering the large increase in natural gas production during this time period, a reduction in the fraction of emitted methane (relative to the produced quantity of natural gas) and VOCs appears probable [Peischl et al., 2018].

Available VOC emissions estimates, differentiated by ethane, benzene, and total VOC, is provided in Table 3. The latest estimate in each category is based on relative observations of $\mathrm{VOC} /$ methane at the Boulder Reservoir during 2017-2018, scaled to the Peischl et al. [2018] methane flux estimate. Therefore, these two data sets are linked to each other. These data are too few, and uncertainty within each data set are too large, for making any valid statement about potential changes in these emissions. 
Table 3

629

Comparison of DJB ethane, benzene, and total VOC flux estimates from published literature.

630

\begin{tabular}{|c|c|c|}
\hline VOC/Year & VOC Best Flux Estimate & Reference \\
\hline & tons $\mathrm{yr}^{-1}$ & \\
\hline \multicolumn{3}{|l|}{ Ethane } \\
\hline 2011 & 29,000 & Swarthout et al., 2013 \\
\hline 2015 & 61,000 & Peischl et al., 2018 \\
\hline $2017 / 2018$ & $36,000 *$ & Helmig et al., manusript in prep. \\
\hline \multicolumn{3}{|l|}{ Benzene } \\
\hline 2011 & 570 & Swarthout et al., 2013 \\
\hline 2012 & 1500 & Petron et al., 2014 \\
\hline $2017 / 2018$ & 620 & Helmig et al., manuscript in prep. \\
\hline \multicolumn{3}{|l|}{ Total VOC } \\
\hline 2006 & 64,000 & Bar-llan et al., 2008 \\
\hline 2011 & 79,000 & Swarthout et al., 2013 \\
\hline $2015^{\prime}$ & $(183000)$ & 3.5 $x$ ethane from Peischl et al., \\
\hline $2017 / 2018$ & 134000* & Helmig et al., manusript in prep. \\
\hline $2017 / 2018$ & $231,000 * *$ & Helmig et al., manusript in prep. \\
\hline \multicolumn{3}{|c|}{ *Derived by scaling 2017/2018 relative VOC/methane O\&NG ratios to the Peischl et al. year 2015 methane flux. } \\
\hline *Derived by scaling & g 2017/2018 relative VOC/ethane & NG ratios to the Peischl et al. year 2015 etr \\
\hline
\end{tabular}

In summary, at this time, there do not appear to be observational records that allow deducing, with statistical significant certainty, if and how methane and/or VOC emissions may have changed in the DJB over the past 15 years. There is no convincing evidence for an overall decrease in VOC emissions at this time. Certainly, none of these data show increases that scale with the DJB O\&NG production increase

638 (e.g. 3.5-6.5 times for natural gas and oil, respectively, for 2010-2018). Therefore, it appears likely that relative emissions rates have declined, likely due to the implementation of stricter emission controls. However, the growth of the number of operations has probably counteracted those relative emissions reductions, resulting in overall basin-wide stable total emissions.

\section{Oil and Natural Gas Emissions and Air Quality}

643 Air quality impacts from O\&NG emissions arise from acute, chronic, and carcinogenic effects of primary 644 emissions, particularly of BTEX VOC in close proximity to operations, and emissions of $\mathrm{NO}_{x}$ and particu645 lates from equipment and on-site power generation. These exposures are of concern for residents living 646 within a few hundred meters to kilometers of O\&NG operations. According to the survey of McKenzie et al. [2016], in 2012, $\approx 56,000$ citizens lived within a radius of 1000 feet of O\&NG operations in Colorado.

648 These populations are at greatest risks for these exposures. Secondary products that are formed via 649 photochemical processing of emissions during transport are another concern. Here, the pollutants of 650 importance are ozone and PM2.5. These species are transported across a wide spatial scale in the NCFR, 651 thereby affecting a much larger population. In excess of 3.5 million people live in the NCFR ozone NAA. 652 Approximately half of the NAA (mostly the northern part) is moderately to heavily influenced by O\&NG 
emissions. This part of the NCFR is where O\&NG emissions have the greatest impact on ozone and exceedances of the NAAQS. Atmospheric levels of particulates are relatively modest in the NCFR, with particulate air quality thresholds being exceeded only occasionally, for instance during wildfire plume transport events and wintertime inversion conditions. Nonetheless, health impacts from particulates originating from O\&NG sources are estimated to be similar as for ozone [Fann et al., 2018]. However, ozone is currently the much more recognized regional pollutant.

Emissions of most primary air pollutants continue downwards trends in most of the United States. This also applies to surface ozone; implementation of pollution control measures has resulted in declining surface ozone across wide geographical scales in developed North American and European countries [Fleming et al., 2018]. For instance, the compilation of ozone trends shown in Figure 6 provides a nice testimony for decreases in ozone production across the U.S. These downward trends are particularly remarkable in light of the population growth, increase in energy demand and production, and climate change, which is driving higher ozone production rates from the increase of ozone precursors and faster reaction rates in a warmer climate. Assessments in the magnitude of this effect vary by study. This ozone 'climate penalty' potentially can be rather significant, with some estimates predicting an up to 3-6 ppb increase in surface ozone per degree of temperature increase [Rasmussen et al., 2012].

Several studies have pointed out a decline of ozone precursor emissions from other source categories (non-O\&NG) in the NCFR. Several publications have noted reductions in DMA NO${ }_{x}$, based on CDPHE NO surface monitoring data [Bishop and Stedman, 2008; Cooper et al., 2012; Abeleira and Farmer, 2017; Bien and Helmig, 2018]. DMA and NCFR declining $\mathrm{NO}_{\mathrm{x}}$ trends are further confirmed by satellite imaging [Witman et al., 2014; Lamsal et al., 2015], and indirectly inferred from the diurnal ozone behavior [Bien and Helmig, 2018]. Because of the distribution of measurement sites, these analyses mostly reflect $\mathrm{NO}_{\mathrm{x}}$ emissions in the DMA and not the entire NCFR, and emission reductions that have been achieved from automobiles and power generation plants.

Trends in VOCs are more difficult to assess. In downtown Denver, there is clear evidence that automobile-associated VOC emissions have been declining [Bishop and Stedman, 2008]. Currently, there are no other publications that have reported DMA or NCFR VOC trend analyses, and there is no peer-reviewed research that supports the State agency's conclusion of "a dramatic decline in ambient levels of oil and gas related VOCs" (Supplemental Materials). Taken together, findings from these Colorado $\mathrm{NO}_{\mathrm{x}}$ and VOC studies from non-O\&G sources mirror the national trend.

Large year-to-year variations in surface ozone causes trend analyses to be sensitive to the chosen time window. Trend behavior can differ substantially for different ozone metrics, i.e. summer versus annual ozone, different percentile values in the ozone distribution, and the MDA8 or the Design Value (the 3year running mean of the $4^{\text {th }}$ highest annual MDA8).

Reddy and Pfister [2016] corrected the dependence of high summer ozone occurrences on the predominance of high pressure weather conditions in their investigation of the 1995-2013 NCFR ozone record. They report that these corrected, deemed more robust time series analyses, showed "...a general increase for the Front Range [MDA8] since 2004, broken only by the recession of late 2008".

Lower ozone percentile values, reflecting mostly nighttime ozone, have clearly increased since 2000, most likely due to a weakening nighttime ozone sink from reaction with NO [Bien and Helmig, 2018]. The increasing low percentile/nighttime ozone values are possibly contributing to the observed increases in mean and median ozone. During 2000-2015, 10 out of 11 DMA/NCRF sites displayed a positive rate of change, with for out of those being statistically significant trends ( $p$-value $<0.05$ ) [Bien and Helmig, 2018]. Trends in the high percentile ozone values that are most relevant for health effects and 
regulatory considerations are more inconsistent. 2000-2014 Design Value time series plots for the DMA/NCFR sites Chatfield, Rock Flats North, South Boulder Creek, Fort Collins West, and the National Renewable Energy Lab in Golden [Evans and Helmig, 2017], suggest a behavior of gradually decreasing values; however, linear regression analyses do not result in statistically significant trends. For the 20002015 window, considering a total of 11 DMA/NCFR sites, and 28 linear regressions for summer ozone $95^{\text {th }}$ percentile values, MDA8, and Design Value trend analyses, 9 slope results were positive and 18 were negative. The two times higher negative values count may suggest a predominance of declining ozone behavior. However, the only statistically significant trend results (three) were all positive, indicating increasing ozone. Inclusion of 2016-2018 data in the ozone trend analysis indicates a steadily declining regional Design Value in the last seven years (Supplemental Materials).

The DMA/NCFR ozone behavior deviates from that of most other regions in the U.S. This is most evident in the summer daytime average ozone trends (Figure 6). While this ozone metric has clearly (at many sites with statistical significance) been heading downwards across the U.S., increasing values were determined for most sites in the DMA/NCFR. Persisting elevated ozone conditions were evident during 2018; ozone data collected by CDPHE in the NCRF were higher than in any of the previous five years, with a season maximum of $89 \mathrm{ppb}$ and 32 exceedance days of the 8-hour $70 \mathrm{ppb}$ NAAQS at the Boulder Reservoir site alone (see Figure 7 for the Boulder Reservoir July 2018 ozone record; additional exceedance days for the ozone NAAQS were recorded in all other months from May - September).

Trends of daytime average ozone, summer Data extracted on: 2016-10-21 daytime avg ozone, 2000-2014: all sites

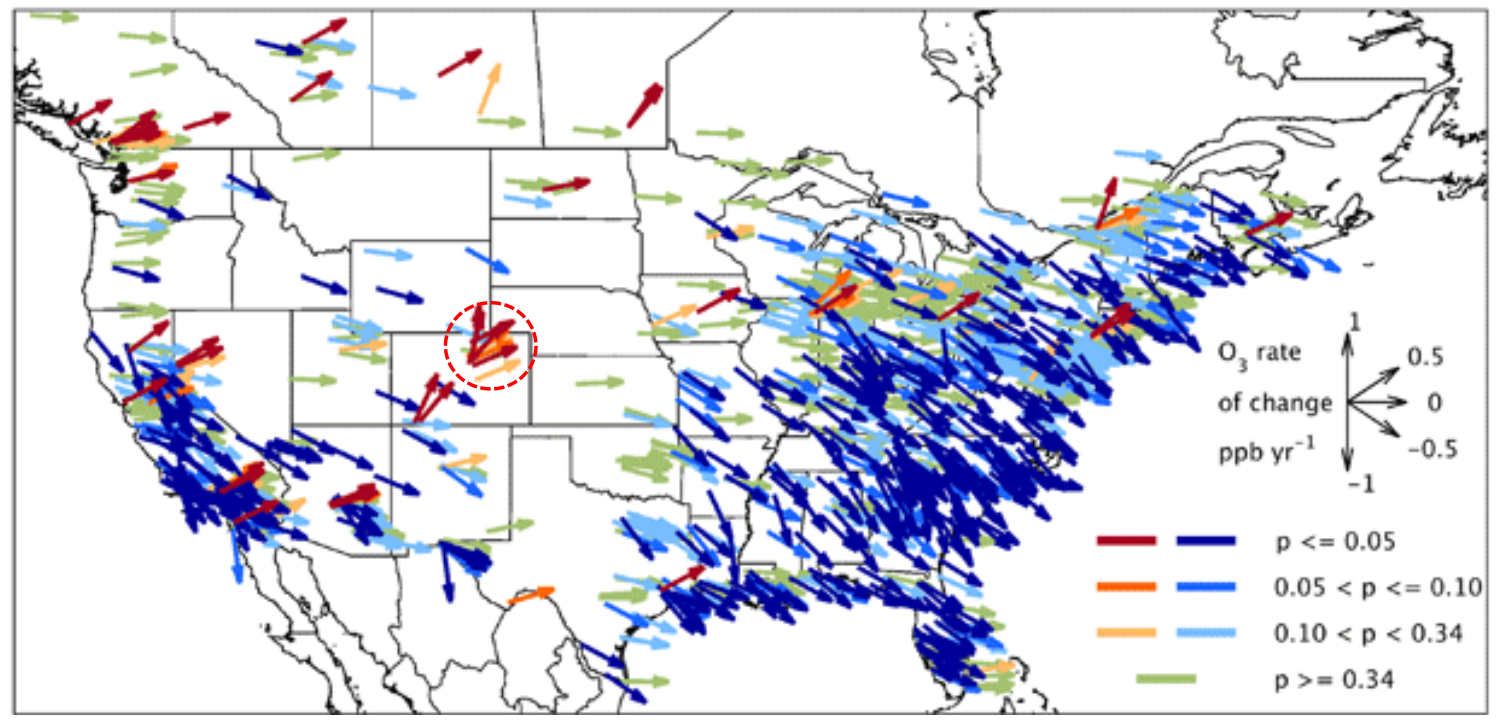

Figure 6: Regional trend analysis of surface ozone observations from monitoring in the U.S. and Canada. These results reflect the 2000 - 2014 changes in summer ozone [Chang et al., 2017]. The arrow direction indicates the sign and magnitude of the ozone trend according to the scale given in the inset (i.e. downward arrows are indicative of declining ozone), and the color coding shows the statistical significance of the ozone change, with statistical significant changes (at $\mathrm{P}>95 \%$ ) indicated by the bold colors. The DMA/NCFR is indicated by the red circle. This figure is a partial reproduction of Figure 1 in Chang et al. (2017). 
There are convincing arguments that support the conclusion that the deviation in the Colorado ozone behavior with the national trend is caused by emissions from the O\&NG sector, both from O\&NG signatures seen in elevated ozone episodes [Cheadle et al., 2017; Oltmans et al., 2019] and from photochemical modeling [Pfister et al., 2017a]. Biogenic VOC emissions have a relatively minor contribution to regional ozone production; elevated ozone episodes are primarily associated with elevated anthropogenic VOCs [Cheadle et al., 2017; Zaragoza et al., 2017; Lindaas et al., 2019]. The effect of O\&NG emissions on ozone production in the NCFR is exacerbated by the dominant summertime air circulation patterns that tend to transport pollution-enriched air from the DJB towards the foothills. Continuing ozone production in these accumulated air masses causes peak ozone values along the westerly parts of the plains stretching from Highlands, along Golden, Boulder, Longmont to Fort Collins and westwards a few miles into the mountain slopes. Boulder County is particularly vulnerable, being the closest and most directly downwind located area of the DJB. This conclusion was stated in the NCAR FRAPPE summary report: "On average, oil and gas emissions show a stronger influence in the northern part of the NFRMA and the northern foothills, while mobile emissions dominate farther south and in the southern foothills. Both sectors contribute, on average, $30-40 \%$ each to total NFRMA ozone production on high ozone days."

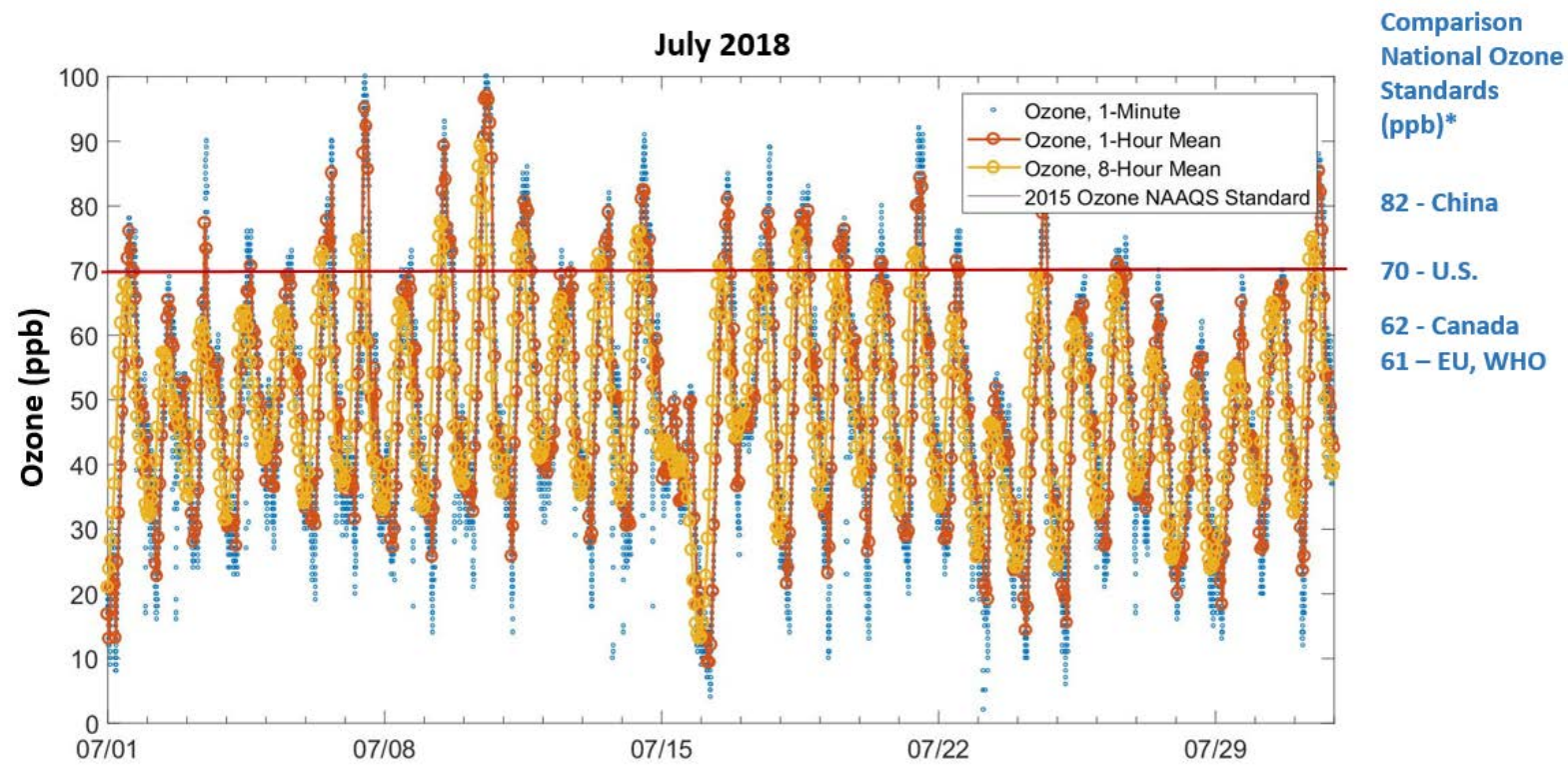

Figure 7: Record of the ozone monitoring by CDPHE at the Boulder Reservoir for July 2018. Data are plotted at the 1-min resolution of the data acquisition, as hourly values, and as 8-hour running mean, which is the regulatory metric. Also shown is the current U.S. ozone NAAQS and, for comparison, 8-hour ozone air quality standards in other selected nations. Shown values are the maximum permitted values to be in compliance. The U.S. and Canada standard applies to the 3-year running mean of the MDA8. *China, the European Union (EU), and the World Health Organization (WHO) list their ozone standards in concentration units. Those were converted to mole fraction values for conditions of $1 \mathrm{~atm}$ and $25^{\circ} \mathrm{C}$. The WHO value is a guideline.

Peer-reviewed literature is consistent in emphasizing that NCFR ozone exceedances are caused by the locally produced ozone that is added to the ozone background that is transported into the State. For Denver, this background is up to $14 \mathrm{ppb}$ higher in comparison to other U.S. cities [EPA, 2008], which lowers the amount of ozone that can be added locally to reach exceedance of the standard. This margin is 
smaller than for other U.S. NAA, making meeting the standard more challenging. However, the local ozone production is mostly within the control of the State. Meeting the standard is calling for a concerted and aggressive effort in curbing regional ozone precursor emissions.

\section{Recommendations}

O\&NG emissions are impacting air quality in the NCFR in multiple ways and at several scales. Exposures in close proximity arise from primary emissions. Current assessments indicate that the most concerning health impacts are from aromatic VOCs (BTEX), and for citizens living within a 1000 feet radius of wells and O\&NG operations. On the order of 3.5 million Colorado residents live in the NCFR ozone NAA. Despite efforts to reduce ozone precursor emissions, and gains made in certain important emission sectors, including transportation and electrical power generation, the region is still subjected to an abundance of elevated ozone occurrences and exceedances of the NAAQS every year. This calls for concerted efforts for better characterizing emissions and air quality impacts of O\&NG emissions and for emissions regulation. Specific recommendations are:

- The lack of long-term $\mathrm{NO}_{x}$ monitoring within the DJB hampers the assessment of the contribution of O\&NG emissions to regional $\mathrm{NO}_{\mathrm{x}}$. $\mathrm{NO}_{\mathrm{x}}$ monitoring should be implemented at key locations upwind, within, and downwind of the DJB. More research is needed to better define $\mathrm{NO}_{\mathrm{x}}$ point emissions from O\&NG facilities. Remote sensing tools and data should be included in the evaluation of O\&NG NO$\times$ sources and emission trends.

- Very little research has been done on evaluating and quantifying the contribution of O\&NG emissions to atmospheric particulates. The prospect of 25-49 premature annual human deaths in Colorado from exposure to particles caused by O\&NG emissions under current industry growth scenarios by 2025 [Fann et al. 2018] should motivate a concerted effort to investigate and better define particulates pollution, and to regulate particulates and secondary aerosol precursor emissions from the industry.

- VOCs data, mostly from occasional and campaign-type data, as well as the CDPHE monitoring at Platteville, clearly show a strong contribution from O\&NG operations on total VOCs and the ozone-producing $\mathrm{VOC}$ reactivity in the region. VOC monitoring is crucial for assessing O\&NG air quality impacts. The current distribution of monitoring sites has a number of shortcomings for evaluating and monitoring changes of O\&NG emissions. VOC monitoring is needed near operations to assess facility emissions and exposure risks of nearby residencies. This monitoring needs to be expanded to activities such as flowback, liquid unloading, and wastewater separation, which appear to be associated with high emissions and which have been mostly neglected or been underrepresented in previous assessments. In order to capture the high variability of these emission, this monitoring should be at high time resolution, ideally in real time. VOC monitoring needs to be tailored for characterizing emission trends, representative for a wide regional footprint. This can, for instance, be achieved by sampling at elevated sites or/and from inlets high above the surface, and best during mid-day to afternoon hours, when chances to sample mixed boundary layer air are highest. This monitoring would be most promising if it is conducted continuously, and at highest possible accuracy. Continuous, concurrent, and coordinated monitoring at strategically selected sites upwind and downwind of the DJB would allow assessing changes in basin-wide emissions. 
- VOCs emitted from O\&NG sources constitute the majority of the OH reactivity in the DJB north of the DMA. These emissions contribute to a temporal and locally variable ozone production. Summertime elevated ozone occurrences show a high correlation to transport from O\&NG extraction regions and atmospheric O\&NG influences. Due to the ozone production dynamics and air circulation patterns, the daytime peak maximum ozone values are often observed along the NCFR foothills, tens of kilometers downwind of the O\&NG emissions source regions, and thereby impacting communities outside of the production regions. These downwind air quality impacts from O\&NG industries should be a strong consideration in the design of monitoring networks and decision-making on regulating existing and new O\&NG development in the region.

- Several independent measurements near O\&NG operations have shown spikes with highly elevated concentrations of BTEX compounds that exceed health risks thresholds for nearby residents. Highest concentrations have been reported downwind of disposal facilities, rather than from well pads. Available data are mostly from short episodic measurements. This clearly demonstrates that characterization of BTEX emissions warrants more attention. This needs to include continuous monitoring and consideration of the diverse types of O\&NG facilities. Thus far, health assessments have predominantly focused on well pads. Further research is needed on incorporating these other emissions sources given the growing body of literature showing their significant emissions and resulting elevated downwind concentrations.

- Bottom-up inventories have large uncertainties, neglect temporal variation, and consistently appear to be lower than top-down emissions determinations. The increase in well sites, the size and number of wells per pad, changes in operational practices, and new regulations make bottom-up emission inventories an ever changing challenge. Inconsistencies between national and state inventories persist. There appears to have been little progress in improving agreement between bottom-up inventory estimates and top-down estimates during the past decade. Experimental tools for aircraft basin-wide top-town emissions determination have improved remarkably during the past five years. A concerted effort building on these capabilities by regularly (e.g. monthly) light aircraft profiling, could, within a short time frame, yield significant improvements of the basin-wide total emissions characterization.

- Assessments of ozone contribution from O\&NG emissions will have high uncertainty, and will under-predict the true ozone production as long as they rely on underestimated O\&NG inventory emissions. Ozone impact studies need to be revisited with consideration on the most realistic $\mathrm{NO}_{x}$ and $\mathrm{VOC}$ emissions from the industry.

- Ozone pollution in the NCFR is well within the range where ecosystem impacts and production yield losses in agriculture are predicted. Given the size of the agricultural industry, and from available literature on ozone effects on crops, it is expected that the economic loss to the State's farming industry from the O\&NG-contributed ozone may be quite significant. A quantification of the actual revenue loss is needed for evaluating these adverse economic impacts of O\&NG industry emissions.

- There has been a remarkable growth in the number of peer-review studies on air quality impacts from O\&NG emissions. Consideration of the findings from these resources, and closer 
communication and collaboration between academic and federal researchers with state regulators will likely be beneficial for directing Colorado's O\&NG policy development, guiding policy implementation, and for monitoring and assessing policy effectiveness.

\section{Acknowledgements}

This research was in part funded by a contract from Earthworks, Durango, Colorado. Helene Angot, William Neff, and Lisa McKenzie, all from the University of Colorado, provided text corrections and proofreading. The detailed comments from four anonymous reviewers and the handling editor were invaluable for the improvement of the manuscript. CDPHE provided monitoring data and network information. Publication fees for this article were covered by the University of Colorado Boulder Libraries Open Access Fund.

\section{Literature Cited}

Abdi-Oskouei, M., G. Pfister, F. Flocke, N. Sobhani, P. Saide, A. Fried, D. Richter, P. Weibring, J. Walega, and G. Carmichael (2018), Impacts of physical parameterization on prediction of ethane concentrations for oil and gas emissions in WRF-Chem, Atmospheric Chemistry and Physics, 18, 16863-16883, doi:10.5194/acp-18-16863-2018.

Abeleira, A., I. B. Pollack, B. Sive, Y. Zhou, E. V. Fischer, and D. K. Farmer (2017), Source characterization of volatile organic compounds in the Colorado Northern Front Range Metropolitan Area during spring and summer 2015, Journal of Geophysical Research, 122, 3595-3613, doi:10.1002/2016jd026227.

Abeleira, A. J., and D. K. Farmer (2017), Summer ozone in the northern Front Range metropolitan area: weekend-weekday effects, temperature dependences, and the impact of drought, Atmospheric Chemistry and Physics, 17, 6517-6529, doi:10.5194/acp-17-6517-2017.

Adgate, J. L., B. D. Goldstein, and L. M. McKenzie (2014), Potential Public Health Hazards, Exposures and Health Effects from Unconventional Natural Gas Development, Environmental Science \& Technology, 48, 8307-8320, doi:10.1021/es404621d.

Archibald, A. T., C. Ordonez, E. Brent, and M. L. Williams (2018), Potential impacts of emissions associated with unconventional hydrocarbon extraction on UK air quality and human health, Air Quality Atmosphere and Health, 11, 627-637, doi:10.1007/s11869-018-0570-8.

Avnery, S., D. L. Mauzerall, J. F. Liu, and L. W. Horowitz (2011), Global crop yield reductions due to surface ozone exposure: 1 . Year 2000 crop production losses and economic damage, Atmospheric Environment, 45, 2284-2296, doi:10.1016/j.atmosenv.2010.11.045.

Bahreini, R., R. Ahmadov, S. A. McKeen, K. T. Vu, J. H. Dingle, E. C. Apel, D. R. Blake, N. Blake, T. L. Campos, C. Cantrell, F. Flocke, A. Fried, J. B. Gilman, A. J. Hills, R. S. Hornbrook, G. Huey, L. Kaser, B. M. Lerner, R. L. Mauldin, S. Meinardi, D. D. Montzka, D. Richter, J. R. Schroeder, M. Stell, D. Tanner, J. Walega, P. Weibring, and A. Weinheimer (2018), Sources and characteristics of summertime organic aerosol in the Colorado Front Range: perspective from measurements and WRF-Chem modeling, Atmospheric Chemistry and Physics, 18, 8293-8312, doi:10.5194/acp-18-8293-2018.

Baier, B. C., W. H. Brune, D. O. Miller, D. Blake, R. Long, A. Wisthaler, C. Cantrell, A. Fried, B. Heikes, S. Brown, E. McDuffie, F. Flocke, E. Apel, L. Kaser, and A. Weinheimer (2017), Higher measured than 
modeled ozone production at increased NOx levels in the Colorado Front Range, Atmospheric Chemistry and Physics, 17, 11273-11292, doi:10.5194/acp-17-11273-2017.

Bar-llan, A., J. Grant, R. Friesen, A. K. Pollack, D. Henderer, D. Pring, and K. Sgamma (2008), Development of baseline 2006 emissions from oil and gas activity in the Denver-Julesburg Basin, Environ Technical Report, https://www.wrapair.org/forums/ogwg/documents/200804_06_Baseline_Emissions_DJ_Basin_Technical_Memo_(04-30).pdf, 34 pp.

Barkley, Z. R., T. Lauvaux, K. J. Davis, A. Deng, A. Fried, P. Weibring, D. Richter, J. G. Walega, J. DiGangi, S. H. Ehrman, X. Ren, and R. R. Dickerson (2019), Estimating Methane Emissions From Underground Coal and Natural Gas Production in Southwestern Pennsylvania, Geophysical Research Letters, 46, 4531-4540, doi:10.1029/2019gl082131.

Bell, M. L., F. Dominici, and J. M. Samet (2005), Meta-analysis of ozone and mortality, Epidemiology, 16, S35-S35, doi:10.1097/00001648-200509000-00075.

Benedict, K. B., A. J. Prenni, A. P. Sullivan, A. R. Evanoski-Cole, E. V. Fischer, S. Callahan, B. C. Sive, Y. Zhou, B. A. Schichtel, and J. L. Collett Jr (2018), Impact of Front Range sources on reactive nitrogen concentrations and deposition in Rocky Mountain National Park, PeerJ, 6, e4759, doi:10.7717/peerj.4759.

Benedict, K. B., Y. Zhou, B. C. Sive, A. J. Prenni, K. A. Gebhart, E. V. Fischer, A. Evanoski-Cole, A. P. Sullivan, S. Callahan, B. A. Schichtel, H. T. Mao, Y. Zhou, and J. L. Collett (2019), Volatile organic compounds and ozone in Rocky Mountain National Park during FRAPPE, Atmospheric Chemistry and Physics, 19, 499-521, doi:10.5194/acp-19-499-2019.

Bien, T., and D. Helmig (2018), Changes in summertime ozone in Colorado during 2000-2015, ElementaScience of the Anthropocene, 6, 1-25, doi:10.1525/elementa.300.

Bishop, G., and D. H. Stedman (2008), A decade of on-road emissions measurements, Environ. Sci. Technol., 45, 1651-1656.

Bogacki, M., and J. Macuda (2014), The influence of shale rock fracturing equipment operation on atmospheric air quality, Archives of Mining Sciences, 59, 897-912, doi:10.2478/amsc-2014-0062.

Brimmer, A. (2019), Overview of 2011/2017 NOx and VOC Emissions Inventory, Regional Air Quality Council, Mobile Sources and Fuels Commitee Meeting Presentation, Februar 27.

Brodin, M., D. Helmig, and S. Oltmans (2010), Seasonal ozone behavior along an elevation gradient in the Colorado Front Range Mountains, Atmospheric Environment, 44, 5305-5315, doi:10.1016/j.atmosenv.2010.06.033.

Brown, S. S., J. A. Thornton, W. C. Keene, A. A. P. Pszenny, B. C. Sive, W. P. Dube, N. L. Wagner, C. J. Young, T. P. Riedel, J. M. Roberts, T. C. VandenBoer, R. Bahreini, F. Ozturk, A. M. Middlebrook, S. Kim, G. Hubler, and D. E. Wolfe (2013), Nitrogen, Aerosol Composition, and Halogens on a Tall Tower (NACHTT): Overview of a wintertime air chemistry field study in the front range urban corridor of Colorado, Journal of Geophysical Research-Atmospheres, 118, 8067-8085, doi:10.1002/jgrd.50537.

CDPHE (2008), Denver Metropolitan Area and North Front Range 8-Hour Ozone State Implementation Plan, http://www.colorado.gov/airquality/documents/deno308/woe_DraftFinal_w\%20preface.pdf, Draft Final, October 29, 2008, 1-85.

CDPHE (2019a), History of Ozone in Colorado, https://www.colorado.gov/pacific/cdphe/ozone-planningchronology, Accessed September 2019. 
CDPHE (2019b), North Front Range Ozone Precursor Monitoring, https://www.colorado.gov/airquality/tech_doc_repository.aspx\#ozone_precursor_data, Accessed Februrary 3, 2019.

CDPHE (2019c), Oil and Gas Compliance and Recordkeeping, https://www.colorado.gov/pacific/cdphe/air/oil-and-gas-compliance, Accessed February 3, 2019.

Chang, K. L., I. Petropavlovskikh, O. R. Cooper, M. G. Schultz, and T. Wang (2017), Regional trend analysis of surface ozone observations from monitoring networks in eastern North America, Europe and East Asia, Elementa-Science of the Anthropocene, 5, doi:10.1525/elementa.243.

Cheadle, L. C., S. J. Oltmans, G. Pétron, R. C. Schnell, E. J. Mattson, S. C. C. Herndon, A. M. Thompson, D. R. Blake, and A. McClure-Begley (2017), Surface ozone in the Colorado northern Front Range and the influence of oil and gas development during FRAPPE/DISCOVER-AQ in summer 2014, Elementa-Science of the Anthropocene, 1-23, doi:10.1525/elementa.254.

Colborn, T., K. Schultz, L. Herrick, and C. Kwiatkowski (2014a), An Exploratory Study of Air Quality Near Natural Gas Operations, Human and Ecological Risk Assessment, 20, 86-105, doi:10.1080/10807039.2012.749447.

Colborn, T., K. Schultz, L. Herrick, and C. Kwiatkowski (2014b), An exploratory study of air quality near natural gas operations, Human and Ecological Risk Assessment: An International Journal, 20, 86-105, doi:10.1080/10807039.2012.749447.

Cooper, O. R., R.-S. Gao, D. Tarasick, T. Leblanc, and C. Sweeney (2012), Long-term ozone trends at rural ozone monitoring sites across the United States, 1990-2010, Journal of Geophysical Research: Atmospheres, 117, n/a-n/a, doi:10.1029/2012jd018261.

Cooper, O. R., A. O. Langford, D. D. Parrish, and D. W. Fahey (2015), Challenges of a lowered US ozone standard, Science, 348, 1096-1097, doi:10.1126/science.aaa5748.

Dingle, J. H., K. Vu, R. Bahreini, E. C. Apel, T. L. Campos, F. Flocke, A. Fried, S. Herndon, A. J. Hills, R. S. Hornbrook, G. Huey, L. Kaser, D. D. Montzka, J. B. Nowak, M. Reeves, D. Richter, J. R. Roscioli, S. Shertz, M. Stell, D. Tanner, G. Tyndall, J. Walega, P. Weibring, and A. Weinheimer (2016), Aerosol optical extinction during the Front Range Air Pollution and Photochemistry Experiment (FRAPPE) 2014 summertime field campaign, Colorado, USA, Atmospheric Chemistry and Physics, 16, 11, doi:10.5194/acp-16-11207-2016.

DISCOVER-AQ (2013), Deriving Information on Surface Conditions from COlumn and VERtically Resolved Observations Relevant to Air Quality https://www-air.larc.nasa.gov/missions/discover-aq/discoveraq.html, Accessed January 11, 2019.

Drilling-Edge (2019), Oil \& Gas Production in Weld County, CO, http://www.drillingedge.com/colorado/weld-county, Accessed January 31, 2019.

Dunker, A. M., B. Koo, and G. Yarwood (2017), Contributions of foreign, domestic and natural emissions to US ozone estimated using the path-integral method in CAMx nested within GEOS-Chem, Atmospheric Chemistry and Physics, 17, 12553-12571, doi:10.5194/acp-17-12553-2017.

Edie, R., A. M. Robertson, S. Murphy, G. Petron, M. Madronich, and B. Vaughn (2019), Could O\&G wastewater be a significant source of air toxics in the Northern Colorado Front Range?, NOAA Earth Systems Research Laboratory Global Monitoring Division Annual Conference, May 21-22, Boulder, CO. EIA (2009), Household Energy Use in Colorado, https://www.eia.gov/consumption/residential/reports/2009/state_briefs/pdf/CO.pdf. 
EPA (2008), Policy Assessment for the Review of the Ozone National Ambient Air Quality Standards, http://www.epa.gov/ttn/naaqs/standards/ozone/s_o3_2008_pa.html, Accessed October 2019.

EPA (2019), News Releases from Region 08. EPA proposes to reclassify Denver area to "Serious" nonattainment for ozone, https://www.epa.gov/newsreleases/epa-proposes-reclassify-denver-area-seriousnon-attainment-ozone, Accessed October 2019.

Evans, J., D. Helmig, and C. R. Thompson (2014), Influence of emissions from oil and gas development on elevated ozone in the northern Colorado Front Range, American Geophysical Union Conference, A13F3246.

Evans, J. M., and D. Helmig (2017), Investigation of the influence of transport from oil and natural gas regions on elevated ozone levels in the northern Colorado front range, Journal of the Air \& Waste Management Association, 67, 196-211.

Fann, N., K. R. Baker, E. A. W. Chan, A. Eyth, A. Macpherson, E. Miller, and J. Snyder (2018), Assessing human health PM2.5 and ozone impacts from US oil and natural gas sector emissions in 2025, Environmental Science \& Technology, 52, 8095-8103, doi:10.1021/acs.est.8b02050.

Ferman, M. A., G. T. Wolff, and N. A. Kelly (1981), An assessment of the gaseous-pollutants and meteorological conditions associated with Denver Brown Cloud, Journal of Environmental Science and Health Part A-Environmental Science and Engineering \& Toxic and Hazardous Substance Control, 16, 315339, doi:10.1080/10934528109374984.

Field, R. A., J. Soltis, and S. Murphy (2014), Air quality concerns of unconventional oil and natural gas production, Environmental Science-Processes \& Impacts, 16, 954-969, doi:10.1039/c4em00081a.

Fleming, Z. L., R. M. Doherty, E. von Schneidemesser, C. S. Malley, O. R. Cooper, J. P. Pinto, A. Colette, X. B. Xu, D. Simpson, M. G. Schultz, A. S. Lefohn, S. Hamad, R. Moolla, S. Solberg, and Z. Z. Feng (2018), Tropospheric Ozone Assessment Report: Present-day ozone distribution and trends relevant to human health, Elementa-Science of the Anthropocene, 6, doi:10.1525/elementa.273.

Franco, B., E. Mahieu, L. K. Emmons, Z. A. Tzompa-Sosa, E. V. Fisher, K. Sudo, B. Bovy, S. Conway, D. Griffin, J. Hannigan, K. Strong, and K. A. Walker (2016), Evaluating ethane and methane emissions associated with the development of oil and natural gas extraction in North America, Environmental Research Letters, 11, 1-11.

Frankenberg, C., A. K. Thorpe, D. R. Thompson, G. Hulley, E. A. Kort, N. Vance, J. Borchardt, T. Krings, K. Gerilowski, C. Sweeney, S. Conley, B. D. Bue, A. D. Aubrey, S. Hook, and R. O. Green (2016), Airborne methane remote measurements reveal heavy-tail flux distribution in Four Corners region, Proceedings of the National Academy of Sciences, 113, 9734-9739, doi:10.1073/pnas.1605617113.

FRAPPE (2013), FRAPPÉ - Front Range Air Pollution and Photochemistry Experiment, https://www2.acom.ucar.edu/frappe, Accessed January 11, 2019.

Gilman, J. B., B. M. Lerner, W. C. Kuster, and J. A. de Gouw (2013), Source signature of volatile organic compounds from oil and natural gas operations in northeastern Colorado, Environmental Science \& Technology, 47, 1297-1305, doi:10.1021/es304119a.

Groblicki, P. J., G. T. Wolff, and R. J. Countess (1981), Visibility-reducting species in the Denver Brown Cloud. 1. Relationships between extinction and chemical composition, Atmospheric Environment, 15, 2473-2484, doi:10.1016/0004-6981(81)90063-9.

Gryparis, A., B. Forsberg, K. Katsouyanni, A. Analitis, G. Touloumi, J. Schwartz, E. Samoli, S. Medina, H. R. Anderson, E. M. Niciu, H. E. Wichmann, B. Kriz, M. Kosnik, J. Skorkovsky, J. M. Vonk, and Z. Dortbudak 
(2004), Acute effects of ozone on mortality from the "Air pollution and health: A European approach" project, American Journal of Respiratory and Critical Care Medicine, 170, 1080-1087, doi:10.1164/rccm.200403-3330C.

Halliday, H. S., A. M. Thompson, A. Wisthaler, D. R. Blake, R. S. Hornbrook, T. Mikoviny, M. Muller, P. Eichler, E. C. Apel, and A. J. Hills (2016), Atmospheric benzene observations from oil and gas production in the Denver-Julesburg Basin in July and August 2014, Journal of Geophysical Research-Atmospheres, 121, 11055-11074, doi:10.1002/2016jd025327.

Heck, W. W., O. C. Taylor, R. Adams, G. Bingham, J. Miller, E. Preston, and L. Weinstein (1982), Assesment of crop loss from ozone, Journal of the Air Pollution Control Association, 32, 353-361, doi:10.1080/00022470.1982.10465408.

HEI (2019), Potential Human Health Effects Associated with Unconventional Oil and Gas Development: A Systematic Review of the Epidemiology Literature (FINAL REPORT), https://heienergy.org/publication/potential-human-health-effects-associated-unconventional-oil-and-gasdevelopment, Accessed October 2019.

Helmig, D., M. Hannigan, J. Milford, and J. Gordon (2015), Air Quality Monitoring to Assess Exposure to Volatile Organic Compounds and Develop Cost-Efficient Monitoring Techniques, Final Report to Boulder County, 1-50.

Helmig, D., S. Rossabi, J. Hueber, P. Tans, S. Montzka, K. Masarie, K. Thoning, C. Plass-Duelmer, A. Claude, L. Carpenter, A. C. Lewis, S. Punjabi, S. Reimann, M. Vollmer, R. Steinbrecher, J. Hannigan, L. Emmons, E. Mahieu, B. Franco, D. Smale, and A. Pozzer (2016), Reversal of global atmospheric ethane and propane trends largely due to US Oil and natural gas production, Nature Geoscience, 9, 490-495, doi: doi:10.1038/ngeo2721.

Holder, C., J. Hader, R. Avanasi, T. Hong, E. Carr, B. Mendez, J. Wignall, G. Glen, B. Guelden, and Y. Wei (2019), Evaluating potential human health risks from modeled inhalation exposures to volatile organic compounds emitted from oil and gas operations, Journal of the Air \& Waste Management Association, https://doi.org/10.1080/10962247.2019.1680459.

Jaffe, D. A., O. R. Cooper, A. M. Fiore, B. H. Henderson, G. S. Tonnesen, A. G. Russell, D. K. Henze, A. O. Langford, M. Y. Lin, and T. Moore (2018), Scientific assessment of background ozone over the US: Implications for air quality management, Elementa-Science of the Anthropocene, 6, doi:10.1525/elementa.309.

Jaffe, D. A., N. Wigder, N. Downey, G. Pfister, A. Boynard, and S. B. Reid (2013), Impact of Wildfires on Ozone Exceptional Events in the Western US, Environmental Science \& Technology, 47, 11065-11072, doi:10.1021/es402164f.

Jaffe, D. A., and N. L. Wigder (2012), Ozone production from wildfires: A critical review, Atmospheric Environment, 51, 1-10, doi:10.1016/j.atmosenv.2011.11.063.

Johnson, R., and J. J. Toth (1982), A climatology of the July 1981 surface flow over northeast Colorado, Department of Atmospheric Science, Colorado State University, Paper No. 342.

Karion, A., C. Sweeney, E. A. Kort, P. B. Shepson, A. Brewer, M. Cambaliza, S. A. Conley, K. Davis, A. Deng, M. Hardesty, S. C. Herndon, T. Lauvaux, T. Lavoie, D. Lyon, T. Newberger, G. Petron, C. Rella, M. Smith, S. Wolter, T. I. Yacovitch, and P. Tans (2015), Aircraft-based Estimete of total methane emissions from the Barnett Shale region, Environmental Science \& Technology, 49, 8124-8131, doi:10.1021/acs.est.5b00217. 
Karion, A., C. Sweeney, G. Petron, G. Frost, M. Hardesty, J. Kofler, B. R. Miller, T. Newberger, S. Wolter, R. Banta, A. Brewer, E. J. Dlugkencky, P. Lang, S. A. Montzka, R. C. Schnell, P. Tans, M. Trainer, R. Zomora, and S. Conley (2013), Methane emissions estimate from airborne measurements over a western United States natural gas field, Geophysical Research Letters, 40, 1-5, doi:10.1002/grl.50811.

Kaser, L., E. G. Patton, G. G. Pfister, A. J. Weinheimer, D. D. Montzka, F. Flocke, A. M. Thompson, R. M. Stauffer, and H. S. Halliday (2017), The effect of entrainment through atmospheric boundary layer growth on observed and modeled surface ozone in the Colorado Front Range, Journal of Geophysical Research: Atmospheres, 122, 6075-6093, doi:doi:10.1002/2016JD026245.

Kille, N., R. Chiu, M. Frey, F. Hase, M. K. She, T. Blumenstock, J. W. Hannigan, J. Orphal, D. Bon, and R. Volkamer (2019), Separation of methane emissions from agricultural and natural gas sources in the Colorado Front Range, Geophysical Research Letters, 46, 3990-3998, doi:10.1029/2019gl082132.

Kirschke, S., P. Bousquet, P. Ciais, M. Saunois, J. G. Canadell, E. J. Dlugokencky, P. Bergamaschi, D. Bergmann, D. R. Blake, L. Bruhwiler, P. Cameron-Smith, S. Castaldi, F. Chevallier, L. Feng, A. Fraser, M. Heimann, E. L. Hodson, S. Houweling, B. Josse, P. J. Fraser, P. B. Krummel, J.-F. Lamarque, R. L. Langenfelds, C. Le Quere, V. Naik, S. O'Doherty, P. I. Palmer, I. Pison, D. Plummer, B. Poulter, R. G. Prinn, M. Rigby, B. Ringeval, M. Santini, M. Schmidt, D. T. Shindell, I. J. Simpson, R. Spahni, L. P. Steele, S. A. Strode, K. Sudo, S. Szopa, G. R. van der Werf, A. Voulgarakis, M. van Weele, R. F. Weiss, J. E. Williams, and G. Zeng (2013), Three decades of global methane sources and sinks, Nature Geoscience, 6, 813-823, doi:10.1038/ngeo1955.

Kort, E. A., C. Frankenberg, K. R. Costigan, R. Lindenmaier, M. K. Dubey, and D. Wunch (2014), Four corners: The largest US methane anomaly viewed from space., Geophysical Research Letters, 41, 68986903, doi:10.1002/285 2014GL061503.

Koss, A., B. Yuan, C. Warneke, J. B. Gilman, B. M. Lerner, P. R. Veres, J. Peischl, S. Eilerman, R. Wild, S. S. Brown, C. R. Thompson, T. Ryerson, T. Hanisco, G. M. Wolfe, J. M. St Clair, M. Thayer, F. N. Keutsch, S. Murphy, and J. de Gouw (2017), Observations of VOC emissions and photochemical products over US oil- and gas-producing regions using high-resolution H3O+ CIMS (PTR-ToF-MS), Atmospheric Measurement Techniques, 10, 2941-2968, doi:10.5194/amt-10-2941-2017.

Kostinek, J., A. Roiger, K. J. Davis, C. Sweeney, J. P. DiGangi, Y. Choi, B. Baier, F. Hase, J. Gross, M. Eckl, T. Klausner, and A. Butz (2019), Adaptation and performance assessment of a quantum and interband cascade laser spectrometer for simultaneous airborne in situ observation of $\mathrm{CH} 4, \mathrm{C} 2 \mathrm{H} 6, \mathrm{CO} 2, \mathrm{CO}$ and N2O, Atmospheric Measurement Techniques, 12, 1767-1783, doi:10.5194/amt-12-1767-2019.

LaFranchi, B. W., G. Pétron, J. B. Miller, S. J. Lehman, A. E. Andrews, E. J. Dlugokencky, B. Hall, B. R. Miller, S. A. Montzka, W. Neff, P. C. Novelli, C. Sweeney, J. C. Turnbull, D. E. Wolfe, P. P. Tans, K. R. Gurney, and T. P. Guilderson (2013), Constraints on emissions of carbon monoxide, methane, and a suite of hydrocarbons in the Colorado Front Range using observations of 14CO2, Atmos. Chem. Phys., 13, 11101-11120, doi:10.5194/acp-13-11101-2013.

Lamsal, L. N., B. N. Duncan, Y. Yoshida, N. A. Krotkov, K. E. Pickering, D. G. Streets, and Z. Lu (2015), U.S. NO2 trends (2005-2013): EPA Air Quality System (AQS) data versus improved observations from the Ozone Monitoring Instrument (OMI), Atmospheric Environment, 110, 130-143, doi:10.1016/j.atmosenv.2015.03.055.

Langford, A. O., K. C. Aikin, C. S. Eubank, and E. J. Williams (2009), Stratospheric contribution to high surface ozone in Colorado during springtime, Geophysical Research Letters, 36, doi:10.1029/2009gl038367. 
1068

Lapina, K., D. K. Henze, J. B. Milford, and K. Travis (2016), Impacts of Foreign, Domestic, and State-Level Emissions on Ozone-Induced Vegetation Loss in the United States, Environmental Science \& Technology, 50, 806-813, doi:10.1021/acs.est.5b04887.

Lefohn, A. S., C. S. Malley, L. Smith, B. Wells, M. Hazucha, H. Simon, V. Naik, G. Mills, M. G. Schultz, E. Paoletti, A. De Marco, X. B. Xu, L. Zhang, T. Wang, H. S. Neufeld, R. C. Musselman, D. Tarasick, M. Brauer, Z. Z. Feng, H. Y. Tang, K. Kobayashi, P. Sicard, S. Solberg, and G. Gerosa (2018), Tropospheric ozone assessment report: Global ozone metrics for climate change, human health, and crop/ecosystem research, Elementa-Science of the Anthropocene, 6, doi:10.1525/elementa.279.

Levi, M. A. (2012), Comment on "Hydrocarbon emissions characterization in the Colorado Front Range: A pilot study" by Gabrielle Pétron et al, Journal of Geophysical Research: Atmospheres, 117, doi:doi:10.1029/2012JD017686.

Lin, M., L. W. Horowitz, R. Payton, A. M. Fiore, and G. Tonnesen (2017), US surface ozone trends and extremes from 1980 to 2014: quantifying the roles of rising Asian emissions, domestic controls, wildfires, and climate, Atmospheric Chemistry and Physics, 17, 2943-2970, doi:10.5194/acp-17-29432017.

Lin, M. Y., A. M. Fiore, L. W. Horowitz, A. O. Langford, S. J. Oltmans, D. Tarasick, and H. E. Rieder (2015), Climate variability modulates western US ozone air quality in spring via deep stratospheric intrusions, Nature Communications, 6, doi:10.1038/ncomms8105.

Lindaas, J., D. K. Farmer, I. B. Pollack, A. Abeleira, F. Flocke, and E. V. Fischer (2019), Acyl peroxy nitrates link oil and natural gas emissions to high ozone abundances in the Colorado Front Range during summer 2015, Journal of Geophysical Research, doi:https://doi.org/10.1029/2018JD028825.

Lu, X., L. Zhang, X. Yue, J. C. Zhang, D. A. Jaffe, A. Stohl, Y. H. Zhao, and J. Y. Shao (2016), Wildfire influences on the variability and trend of summer surface ozone in the mountainous western United States, Atmospheric Chemistry and Physics, 16, 14687-14702, doi:10.5194/acp-16-14687-2016.

Macey, G. P., R. Breech, M. Chernaik, C. Cox, D. Larson, D. Thomas, and D. O. Carpenter (2014), Air concentrations of volatile compounds near oil and gas production: a community-based exploratory study, Environ. Health, 13, doi:10.1186/1476-069x-13-82.

Madronich, M., A. Crotwell, E. Dlugokencky, A. Giniewek, B. D. Hall, P. Handley, J. Kofler, B. Kahn, I. Mielke-Maday, B. R. Miller, J. Mund, G. Petron, and K. Thoning (2019), Measuring BTEX with a commercial GC-PID system in an oil and gas field, NOAA Earth Systems Research Laboratory Global Monitoring Division Annual Conference, May 21-22, Abstract P-14.

Majid, A., M. V. Martin, L. N. Lamsal, and B. N. Duncan (2017), A decade of changes in nitrogen oxides over regions of oil and natural gas activity in the United States, Elementa-Science of the Anthropocene, 5, doi:10.1525/elementa.259.

McDuffie, E. E., P. M. Edwards, J. B. Gilman, B. M. Lerner, W. P. Dube, M. Trainer, D. E. Wolfe, W. M. Angevine, J. deGouw, E. J. Williams, A. G. Tevlin, J. G. Murphy, E. V. Fischer, S. McKeen, T. B. Ryerson, J. Peischl, J. S. Holloway, K. Aikin, A. O. Langford, C. J. Senff, R. J. Alvarez, II, S. R. Hall, K. Ullmann, K. O. Lantz, and S. S. Brown (2016), Influence of oil and gas emissions on summertime ozone in the Colorado Northern Front Range, Journal of Geophysical Research-Atmospheres, 121, 8712-8729, doi:10.1002/2016jd025265.

McKenzie, L. M., W. B. Allshouse, T. Burke, B. D. Blair, and J. L. Adgate (2016), Population size, growth, and environmental justice near oil and gas wells in Colorado, Environmental Science \& Technology, 50, 11471-11480, doi:10.1021/acs.est.61304391. 
McKenzie, L. M., W. B. Allshouse, T. E. Byers, E. J. Bedrick, B. Serdar, and J. L. Adgate (2017), Childhood hematologic cancer and residential proximity to oil and gas development, Plos One, 12, doi:10.1371/journal.pone.0170423.

McKenzie, L. M., B. Blair, J. Hughes, W. B. Allshouse, N. J. Blake, D. Helmig, P. Milmoe, H. Halliday, D. R. Blake, and J. L. Adgate (2018), Ambient nonmethane hydrocarbon levels along Colorado's Northern Front Range: Acute and chronic health risks, Environmental Science \& Technology, 52, 4514-4525, doi:10.1021/acs.est.7b05983.

McKenzie, L. M., J. Crooks, J. L. Peel, B. D. Biafr, S. Brindley, W. B. Allshouse, S. Malin, and J. L. Adgate (2019), Relationships between indicators of cardiovascular disease and intensity of oil and natural gas activity in Northeastern Colorado, Environmental Research, 170, 56-64, doi:10.1016/j.envres.2018.12.004.

McKenzie, L. M., R. Guo, R. Z. Witter, D. A. Savitz, L. S. Newman, and J. L. Adgate (2014), Birth Outcomes and Natural Gas Development: McKenzie et al. Respond, Environmental Health Perspectives, 122, A232A233, doi:10.1289/ehp.1408647R.

McKenzie, L. M., R. Z. Witter, L. S. Newman, and J. L. Adgate (2012), Human health risk assessment of air emissions from development of unconventional natural gas resources, Science of the Total Environment, 424, 79-87, doi:10.1016/j.scitotenv.2012.02.018.

McMullin, T. S., A. M. Bamber, D. Bon, D. I. Vigil, and M. Van Dyke (2018), Exposures and health risks from volatile organic compounds in communities located near oil and gas exploration and production activities in Colorado (USA), International journal of environmental research and public health, 15, doi:10.3390/ijerph15071500.

Mielke-Maday, I., M. Madronich, M. Handley, J. Kofler, B. D. Hall, B. R. Miller, J. Mund, D. Kitzis, P. Lang, A. Crotwell, M. J. Crotwell, E. Moglia, T. K. Mefford, B. Vaughn, R. C. Schnell, and G. Petron (2019), Characterization and quantification of benzene emissions from a new multiwell pad in a Colorado Front Range residential community, NOAA Earth Systems Research Laboratory Global Monitoring Division Annual Conference, May 21-22.

Mills, G., H. Pleijel, C. S. Malley, B. Sinha, O. R. Cooper, M. G. Schultz, H. S. Neufeld, D. Simpson, K. Sharps, Z. Z. Feng, G. Gerosa, H. Harmens, K. Kobayashi, P. Saxena, E. Paoletti, V. Sinha, and X. B. Xu (2018), Tropospheric Ozone Assessment Report: Present-day tropospheric ozone distribution and trends relevant to vegetation, Elementa-Science of the Anthropocene, 6, doi:10.1525/elementa.302.

Morgan, P. B., E. A. Ainsworth, and S. P. Long (2003), How does elevated ozone impact soybean? A meta-analysis of photosynthesis, growth and yield, Plant Cell and Environment, 26, 1317-1328, doi:10.1046/j.0016-8025.2003.01056.x.

Neff, W. D. (1997), The Denver Brown Cloud studies from the perspective of model assessment needs and the role of meteorology, Journal of the Air \& Waste Management Association, 47, 269-285, doi:10.1080/10473289.1997.10464447.

Ogburn, S. P. (2014), Colorado first state to limit methane pollution from oil and gas wells, Scientific American, https://www.scientificamerican.com/article/colorado-first-state-to-limit-methane-pollutionfrom-oil-and-gas-wells/, Accessed December 6, 2019.

Oltmans, S. J., L. C. Cheadle, B. J. Johnson, R. C. Schnell, D. Helmig, A. M. Thompson, P. Cullis, E. Hall, A. Jordan, C. Sterling, A. McClure-Begley, J. T. Sullivan, T. J. McGee, and D. Wolfe (2019), Boundary layer ozone in the Northern Colorado Front Range in July-August 2014 during FRAPPE and DISCOVER-AQ from vertical profile measurements, Elememta Science of the Anthropocene, 7, 1-14. 
Peischl, J., S. J. Eilerman, J. A. Neuman, K. C. Aikin, J. de Gouw, J. B. Gilman, S. C. Herndon, R. Nadkarni, M. Trainer, C. Warneke, and T. B. Ryerson (2018), Quantifying methane and ethane emissions to the atmosphere from Central and Western U.S. oil and natural gas production regions, Journal of Geophysical Research: Atmospheres, 123, 7725-7740, doi:doi:10.1029/2018JD028622.

Peischl, J., T. B. Ryerson, K. C. Aikin, J. A. de Gouw, J. B. Gilman, J. S. Holloway, B. M. Lerner, R. Nadkarni, J. A. Neuman, J. B. Nowak, M. Trainer, C. Warneke, and D. D. Parrish (2015), Quantifying atmospheric methane emissions from the Haynesville, Fayetteville, and northeastern Marcellus shale gas production regions, Journal of Geophysical Research-Atmospheres, 120, 2119-2139, doi:10.1002/2014jd022697.

Pétron, G., G. Frost, B. R. Miller, A. I. Hirsch, S. A. Montzka, A. Karion, M. Trainer, C. Sweeney, A. E. Andrews, L. Miller, J. Kofler, A. Bar-Ilan, E. J. Dlugokencky, L. Patrick, C. T. Moore, T. B. Ryerson, C. Siso, W. Kolodzey, P. M. Lang, T. Conway, P. Novelli, K. Masarie, B. Hall, D. Guenther, D. Kitzis, J. Miller, D. Welsh, D. Wolfe, W. Neff, and P. Tans (2012), Hydrocarbon emissions characterization in the Colorado Front Range: A pilot study, Journal of Geophysical Research-Atmospheres, 117, 1-19, doi:10.1029/2011jd016360.

Pétron, G., G. J. Frost, M. K. Trainer, B. R. Miller, E. J. Dlugokencky, and P. Tans (2013), Reply to comment on "Hydrocarbon emissions characterization in the Colorado Front Range-A pilot study" by Michael A. Levi, Journal of Geophysical Research-Atmospheres, 118, 236-242, doi:10.1029/2012jd018487.

Petron, G., A. Karion, C. Sweeney, B. R. Miller, S. A. Montzka, G. J. Frost, M. Trainer, P. Tans, A. Andrews, J. Kofler, D. Helmig, D. Guenther, E. Dlugokencky, P. Lang, T. Newberger, S. Wolter, B. Hall, P. Novelli, A. Brewer, S. Conley, M. Hardesty, R. Banta, A. White, D. Noone, D. Wolfe, and R. Schnell (2014), A new look at methane and nonmethane hydrocarbon emissions from oil and natural gas operations in the Colorado Denver-Julesburg Basin, Journal of Geophysical Research-Atmospheres, 119, 6836-6852, doi:10.1002/2013jd021272.

Pfister, G., F. Flocke, R. S. Hornbrook, J. Orlando, and S. Lee (2017a), Process-Based and Regional Source Impact Analysis for FRAPPE and DISCOVER-AQ 2014, Final Report to the Colorado Department of Public Health and Environment, 31 July, 2017.

Pfister, G. G., P. J. Reddy, M. C. Barth, F. F. Flocke, A. Fried, S. C. Herndon, B. C. Sive, J. T. Sullivan, A. M. Thompson, T. I. Yacovitch, A. J. Weinheimer, and A. Wisthaler (2017b), Using Observations and SourceSpecific Model Tracers to Characterize Pollutant Transport During FRAPPÉ and DISCOVER-AQ, Journal of Geophysical Research: Atmospheres, 122, 10,510-510,538, doi:doi:10.1002/2017JD027257.

Post, D. (2019), Polis withdraws request to EPA for more time to bring Colorado into compliance with federal air-quality standards, Kieran Nicholson.

Rasmussen, D. J., A. M. Fiore, V. Naik, L. W. Horowitz, S. J. McGinnis, and M. G. Schultz (2012), Surface ozone-temperature relationships in the eastern US: A monthly climatology for evaluating chemistryclimate models, Atmospheric Environment, 47, 142-153, doi:10.1016/j.atmosenv.2011.11.021.

Reddy, P. J., and G. G. Pfister (2016), Meteorological factors contributing to the interannual variability of midsummer surface ozone in Colorado, Utah, and other western US states, Journal of Geophysical Research-Atmospheres, 121, 2434-2456, doi:10.1002/2015jd023840.

Richter, D., P. Weibring, J. G. Walega, A. Fried, S. M. Spuler, and M. S. Taubman (2015), Compact highly sensitive multi-species airborne mid-IR spectrometer, Applied Physics B, 119, 119-131, doi:10.1007/s00340-015-6038-8.

Robertson, A. M., R. Edie, D. Snare, J. Soltis, R. A. Field, M. D. Burkhart, C. S. Bell, D. Zimmerle, and S. M. Murphy (2017), Variation in methane emission rates from well pads in four oil and gas basins with 
contrasting production volumes and compositions, Environmental Science \& Technology, 51, 8832-8840, doi:10.1021/acs.est.7b00571.

Rodriguez, M. A., M. G. Barna, and T. Moore (2009), Regional impacts of oil and gas development on ozone formation in the Western United States, Journal of the Air \& Waste Management Association, 59, 1111-1118, doi:10.3155/1047-3289.59.9.1111.

Rossabi, S., J. Evans, C. Thompson, J. Hueber, K. Smith, T. Reed, W. Wang, and G. Pfister (2017), Surface observations of volatile organic compounds along an elevation gradient in the Northern Colorado Front Range during FRAPPE, Presented at FRAPPE Science Team Meeting, Boulder, CO, May 2-3.

Rossabi, S., J. Hueber, R. Terrell, K. Smith, W. Wang, P. Millmoe, and D. Helmig (2019), Atmospheric distribution of volatile organic oil and natural gas compounds in the Northern Colorado Front Range during FRAPPE and DISCOVERY-AQ, Submitted for Publicaiton.

Sloane, C. S., J. Watson, J. Chow, L. Pritchett, and L. W. Richards (1991), Size-segregated fine particle measurements by chemical-species and their impact on visibility impairment in Denver, Atmospheric Environment, 25, 1013-1024, doi:10.1016/0960-1686(91)90143-u.

Smith, M. L., A. Gvakharia, E. A. Kort, C. Sweeney, S. A. Conley, I. C. Faloona, T. Newberger, R. Schnell, S. Schwietzke, and S. Wolter (2017), Airborne quantification of methane emissions over the Four Corners region, Environ. Sci. Technol., doi:DOI: 10.1021/acs.est.6b06107.

Sovacool, B. K. (2014), Cornucopia or curse? Reviewing the costs and benefits of shale gas hydraulic fracturing (fracking), Renewable \& Sustainable Energy Reviews, 37, 249-264, doi:10.1016/j.rser.2014.04.068.

Sullivan, J. T., T. J. McGee, A. O. Langford, R. J. Alvarez II, C. J. Senff, P. J. Reddy, A. M. Thompson, L. W. Twigg, G. K. Sumnicht, P. Lee, A. Weinheimer, C. Knote, R. W. Long, and R. M. Hoff (2016), Quantifying the contribution of thermally driven recirculation to a high-ozone event along the Colorado Front Range using lidar, Journal of Geophysical Research: Atmospheres, 121, 10,377-310,390, doi:doi:10.1002/2016JD025229.

Swain, T. E. (2018), Weld County Oil \& Gas Update February 2018, https://www.weldgov.com/UserFiles/Servers/Server_6/File/Departments/Planning\%20\&\%20Zoning/Oil \%20and\%20Gas/Updates/Oil\%20\%20Gas\%20Update\%20FEB\%202018.pdf.

Swarthout, R. F., R. S. Russo, Y. Zhou, A. H. Hart, and B. C. Sive (2013), Volatile organic compound distributions during the NACHTT campaign at the Boulder Atmospheric Observatory: Influence of urban and natural gas sources, Journal of Geophysical Research, 118, 10614-10637.

Szoke, E. J. (1991), Eye of the Denver Cyclone, Monthly Weather Review, 119, 1283-1292, doi:10.1175/1520-0493(1991)119<1283:eotdc>2.0.co;2.

Thompson, C. R., J. Hueber, and D. Helmig (2014), Influence of oil and gas emissions on ambient atmospheric non-methane hydrocarbons in residential areas of Northeastern Colorado, ElementaScience of the Anthropocene, 3, 1-17, doi:http://doi.org/10.12952/journal.elementa.000035.

Thompson, T. M., M. A. Rodriguez, M. G. Barna, K. A. Gebhart, J. L. Hand, D. E. Day, W. C. Malm, K. B. Benedict, J. L. Collett, and B. A. Schichtel (2015), Rocky Mountain National Park reduced nitrogen source apportionment, Journal of Geophysical Research-Atmospheres, 120, 4370-4384, doi:10.1002/2014jd022675.

Townsend-Small, A., E. C. Botner, K. L. Jimenez, J. R. Schroeder, N. J. Blake, S. Meinardi, D. R. Blake, B. C. Sive, D. Bon, J. H. Crawford, G. Pfister, and F. M. Flocke (2016), Using stable isotopes of hydrogen to 
quantify biogenic and thermogenic atmospheric methane sources: A case study from the Colorado Front Range, Geophysical Research Letters, 43, 11,462-411,471, doi:doi:10.1002/2016GL071438.

1241 Tzompa-Sosa, Z. A., E. Mahieu, B. Franco, C. A. Keller, A. J. Turner, D. Helmig, A. Fried, D. Richter, P. 1242 Weibring, J. Walega, T. I. Yacovitch, S. C. Herndon, D. R. Blake, F. Hase, J. W. Hannigan, S. Conway, K. 1243 Strong, M. Schneider, and E. V. Fischer (2017), Revisiting global fossil fuel and biofuel emissions of ethane, Journal of Geophysical Research-Atmospheres, 122, 2493-2512, doi:10.1002/2016jd025767. Fried, D. Richter, P. Weibring, J. Walega, D. R. Blake, J. W. Hannigan, I. Ortega, S. Conway, K. Strong, and E. V. Fischer (2019), Atmospheric implications of large C2-C5 alkane emissions from the U.S. oil and gas Industry, Journal of Geophysical Research, 124, 1148-1169. USDA (2018), Colorado Agriculturual Statistics 2018, https://www.nass.usda.gov/Statistics_by_State/Colorado/Publications/Annual_Statistical_Bulletin/Bulle tin2018.pdf, Accessed October 2019.

Van Dingenen, R., F. J. Dentener, F. Raes, M. C. Krol, L. Emberson, and J. Cofala (2009), The global impact of ozone on agricultural crop yields under current and future air quality legislation, Atmospheric Environment, 43, 604-618, doi:10.1016/j.atmosenv.2008.10.033. Schnell, and D. Nummedal (2018), Temporal variability largely explains top-down/bottom-up difference in methane emission estimates from a natural gas production region, Proceedings of the National Academy of Sciences of the United States of America, 115, 11712-11717, doi:10.1073/pnas.1805687115. doi:10.1080/15298660008984534. S. C. Herndon, A. J. Hills, R. S. Hornbrook, G. Huey, L. Kaser, D. D. Montzka, J. B. Nowak, S. E. Pusede, D. Richter, J. R. Roscioli, G. W. Sachse, S. Shertz, M. Stell, D. Tanner, G. S. Tyndall, J. Walega, P. Weibring, A. J. Weinheimer, G. Pfister, and F. Flocke (2016), Impacts of the Denver Cyclone on regional air quality and aerosol formation in the Colorado Front Range during FRAPPÉ 2014, Atmospheric Chemistry and Physics, 16, 12039-12058, doi:10.5194/acp-16-12039-2016.

Waggoner, A. P., R. E. Weiss, and N. C. Ahlquist (1983), The color of Denver haze, Atmospheric Environment, 17, 2081-2086, doi:10.1016/0004-6981(83)90366-9.

West, J. J., and A. M. Fiore (2005), Management of tropospheric ozone by reducing methane emissions, Environmental Science \& Technology, 39, 4685-4691, doi:10.1021/es048629f.

1272 West, J. J., A. M. Fiore, L. W. Horowitz, and D. L. Mauzerall (2006), Global health benefits of mitigating ozone pollution with methane emission controls, Proceedings of the National Academy of Sciences of the United States of America, 103, 3988-3993, doi:10.1073/pnas.0600201103.

1275 WHO, W.-H.-O. (2019), Exposure to Benzene: A major Health Concern, 1276 https://www.who.int/ipcs/features/benzene.pdf.

1277 Wilczak, J. M., and T. W. Christian (1990), Case study of an orographically induced mesoscale vortex 1278 (Denver Cyclone), Monthly Weather Review, 118, 1082-1102, doi:10.1175/1520-

1279 0493(1990)118<1082:csoaoi>2.0.co;2. 
Wilczak, J. M., and J. W. Glendening (1988), Observations and and mixed-layer modeling of a terraininduced mesoscale gyre - the Denver Cyclone, Monthly Weather Review, 116, 2688-2711, doi:10.1175/1520-0493(1988)116<2688:oamlmo>2.0.co;2.

Witman, S., T. Holloway, and P. Reddy (2014), Integrating satellite data into air quality management, Environmental Manager, 34-38.

Wolff, G. T., R. J. Countess, P. J. Groblicki, M. A. Ferman, S. H. Cadle, and J. L. Muhlbaier (1981), Visibilityreducing species in the Denver Brown Cloud. 2. Sources and temporal patterns, Atmospheric Environment, 15, 2485-2502, doi:10.1016/0004-6981(81)90064-0.

WRAP (2009), Western Regional Air Partnership - Oil \& Gas Emissions Workgroup, http://www.wrapair.org/forums/ogwg/index.html, (Accessed October 2019).

Yacovitch, T. I., C. Daube, T. L. Vaughn, C. S. Bell, J. R. Roscioli, W. B. Knighton, D. D. Nelson, D. Zimmerle, G. Pétron, and S. C. Herndon (2017), Natural gas facility methane emissions: measurements by tracer flux ratio in two US natural gas producing basins, Elementa Science of the Anthropocene, 1-12, doi: https://doi.org/10.1525/elementa.251.

Yacovitch, T. I., S. C. Herndon, G. Petron, J. Kofler, D. Lyon, M. S. Zahniser, and C. E. Kolb (2015), Mobile Laboratory Observations of Methane Emissions in the Barnett Shale Region, Environmental Science \& Technology, 49, 7889-7895, doi:10.1021/es506352j.

Yacovitch, T. I., B. Neininger, S. C. Herndon, H. D. van der Gon, S. Jonkers, J. Hulskotte, J. R. Roscioli, and D. Zavala-Araiza (2018), Methane emissions in the Netherlands: The Groningen field, Elementa-Science of the Anthropocene, 6, doi:10.1525/elementa.308.

Zaragoza, J., S. Callahan, E. E. McDuffie, J. Kirkland, P. Brophy, L. Durrett, D. K. Farmer, Y. Zhou, B. Sive, F. Flocke, G. Pfister, C. Knote, A. Tevlin, J. Murphy, and E. V. Fischer (2017), Observations of acyl peroxy nitrates during the Front Range Air Pollution and Photochemistry Experiment (FRAPPE), Journal of Geophysical Research-Atmospheres, 122, 12416-12432, doi:10.1002/2017jd027337.

Zhang, L., D. J. Jacob, N. V. Downey, D. A. Wood, D. Blewitt, C. C. Carouge, A. van Donkelaar, D. B. A. Jones, L. T. Murray, and Y. Wang (2011), Improved estimate of the policy-relevant background ozone in the United States using the GEOS-Chem global model with $1 / 2$ degrees $\times 2 / 3$ degrees horizontal resolution over North America, Atmospheric Environment, 45, 6769-6776, doi:10.1016/j.atmosenv.2011.07.054. 


\section{Supplemental Materials}

1312

1313

1314

1315

1316

1317

1318

1319

1320

1321

1322

1323

1324

1325

1326

$1327 \quad$ List of Contents

1328

1329 CDPHE Comment Letter to EPA

1330 Determination of Colorado Summer Background Ozone

\section{Detlev Helmig ${ }^{1,2, *}$}

${ }^{1}$ Institute of Arctic and Alpine Research, 4001 Discovery Dr., University of Colorado Boulder, CO 80309, USA

${ }^{2}$ Boulder A.I.R. L.L.C., 2820 Lafayette Dr., Boulder, CO 80305, USA

*Detlev.Helmig@colorado.edu

December 10, 2019
Page 2

Page 12 
U.S. Environmental Protection Agency

EPA Docket Center

EPA-HQ-OAR-2018-0226

Mail Code 28221T

1200 Pennsylvania Avenue, NW

Washington, DC 20460

\section{Re: Docket ID No. EPA-HQ-OAR-2018-0226}

To Whom It May Concern:

The Colorado Department of Public Health and Environment (CDPHE) and Regional Air Quality Council (RAQC) submit the following comments on the U.S. Environmental Protection Agency's proposed Determinations of Attainment by the Attainment Date, Extensions of the Attainment Date, and Reclassification of Several Areas Classified as Moderate for the 2008 Ozone National Ambient Air Quality Standards, published on November 14, 2018 in the Federal Register ${ }^{1}$ (hereinafter referred to as the "Determinations"). We want to thank the EPA for proposing to grant Colorado the attainment date extension provided for under the federal Clean Air Act, Section 181, 42 U.S.C. \$7511(a)(5), and for soliciting comments on a variety of timelines related to submittal deadlines for elements of a State Implementation Plan (SIP) for areas classified as Serious nonattainment for the 2008 National Ambient Air Quality Standard for ozone (2008 NAAQS).

Colorado is commited to aggressively pursuing strategies to reduce ozone precursor emissions and bring down ground-level ozone values in order to protect the health of our citizens. Over the past decade, Colorado has been a leader in developing innovative strategies to significantly reduce volatile organic compound (VOC) and nitrogen oxide emissions $\left(\mathrm{NO}_{\mathrm{x}}\right)$ from various industrial sectors. ${ }^{2}$ In 2010 and 2011, the Colorado Legislature enacted the "Clean Air Clean Jobs Act" and the Colorado Air Quality Control Commission (Commission) adopted its Regional Haze SIP, reducing $\mathrm{NO}_{\mathrm{x}}$ emissions from power plants by tens of thousands of tons per year. Since then, Colorado's power producers have continued to commit to transitioning to cleaner forms of energy, which will result in significant additional $\mathrm{NO}_{\mathrm{x}}$ emissions in the coming years.

Over the past several years, Colorado has completed a number of sucessful initiatives aimed at reducing VOC emissions from the oil and gas sector. In 2014, Colorado adopted cutting-edge, first-in-thenation rules to reduce VOC and methane emissions from oil and gas exploration and production and

\footnotetext{
${ }^{1} 83$ Fed. Reg. 56,781 (Nov. 14, 2018).

${ }^{2}$ See, e.g., Colorado Air Quality Control Commission Regulation Number 7, Statement of Basis and Purpose, $\S \S$ XXI.G, XXI.I, XXI.J, and XXI.K.
}

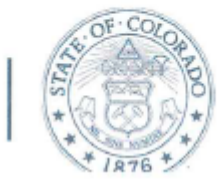


midstream facilities. ${ }^{3}$ Colorado estimated that these rules would result in annual VOC emission reductions of nearly 100,000 tons per year. In recognition of this achievement, Colorado received EPA's Clean Air Excellence Award for Regulatory/Policy Innovations. Since that time, Colorado has continued its efforts to reduce VOC emissions, passing additional regulations addressing ozone precursors in 2016 and 2017. In 2018, Colorado adopted new control measures and work practice standards for engines, boilers, turbines, and other combustion equipment. Also in 2018, Colorado adopted new measures applicable to breweries. During the 2017 and 2018 ozone seasons CDPHE spearheaded a voluntary emission reduction effort aimed at the oil and gas industry and other significant sources of VOCs. Finally, in 2018, CDPHE finalized a comprehensive set of guidelines for the design, operation, and maintenance of condensate storage tanks, which have long been the largest source of VOC emissions in the Denver Metro/North Front Range ozone nonattainment area (DMNFR). As a result of all of these efforts, Colorado has seen a dramatic decline in ambient levels of oil and gas related VOCs. The below chart shows the downward trend in DMNFR ozone design values at the sites with the highest 3-year average of the $4^{\text {th }}$ maximum 8 -hour ozone in parts per billion.

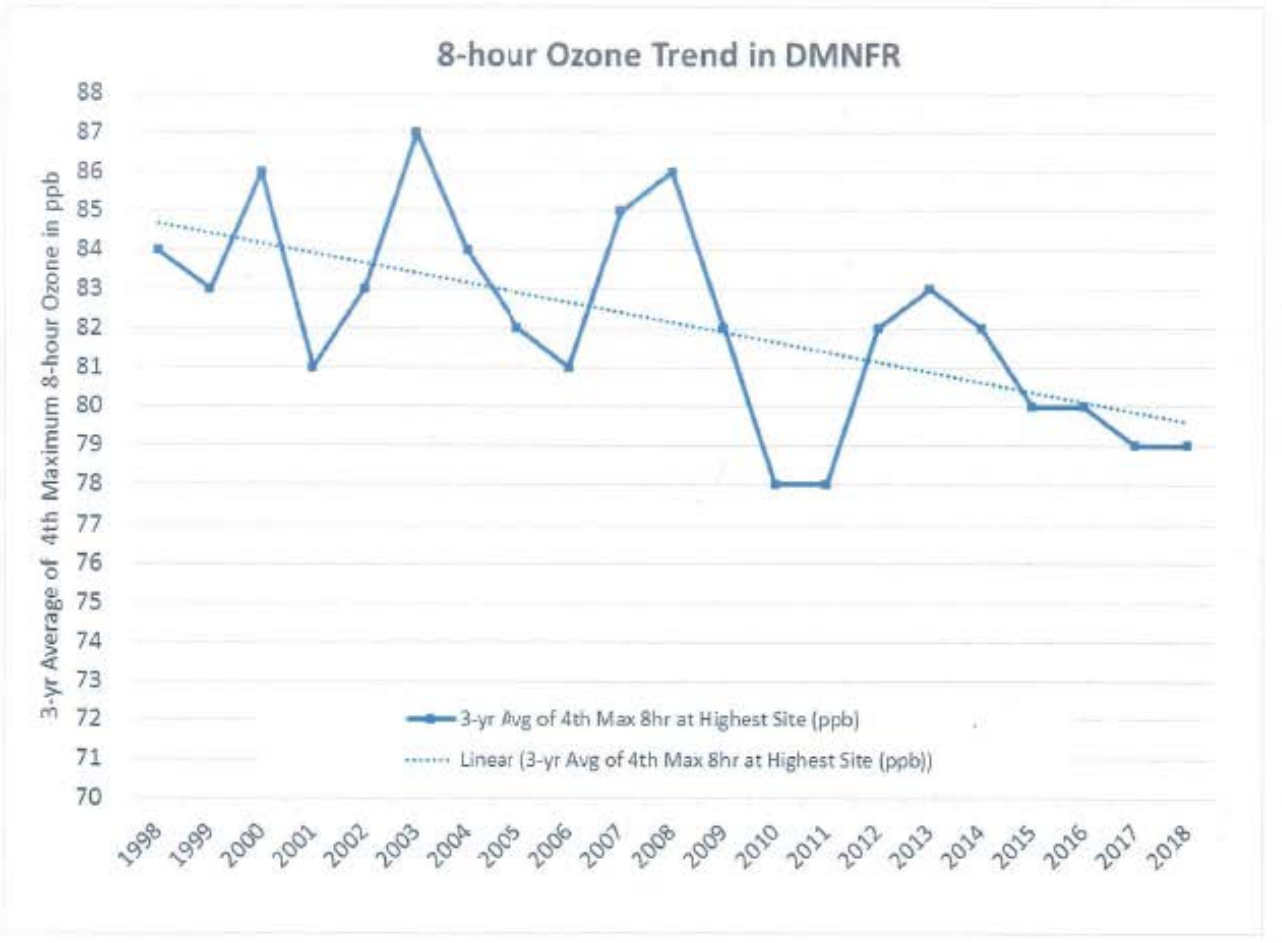

The second chart below shows the downward trend in non-methane organic compounds based on samples gathered in the downtown area of Denver compared with samples gathered in the Platteville area, which is located in the oil and gas production area of the DMNFR.

\footnotetext{
${ }^{3}$ See Regulation Number 7, Statement of Basis and Purpose, $\S$ XXI.N. Significantly, Colorado proactively adopted the 2014 requirements on a state-only basis, not because it was required to as part of a federally mandated SIP.
}

4300 Cherry Creek Drive South, Denver, CO 80246-1530 P 303-692-2000 www.colorado.gov/cdphe John W. Hickenlooper, Govemor | Karin McGowan, Interim Executive Director 


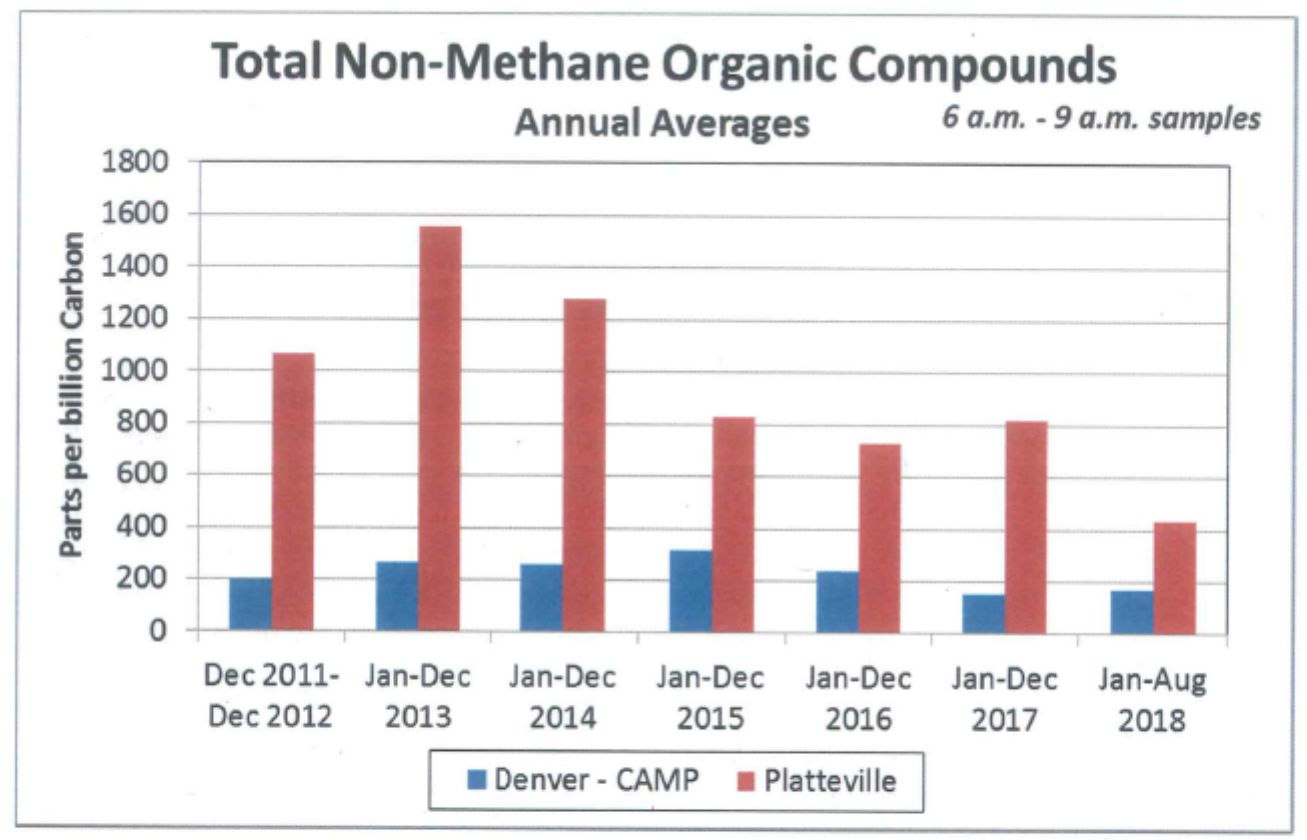

Despite its success in dramatically reducing VOC and $\mathrm{NO}_{\mathrm{x}}$ emissions, Colorado continues to face challenges in meeting both the 2008 and 2015 NAAQS. This is due in large part to the fact that the large majority of ozone concentrations in the DMNFR are the result of emissions outside of the State's control, including naturally occurring emissions and emissions transported from other states and countries. Given this reality, and the fact that Colorado has already significantly reduced ozone precursor emissions within the DMNFR and across the State, achieving additional reductions in ambient ozone levels will require time and hard work to develop and implement meaningful emission reduction strategies.

Fortunately, this work is already underway. Currently, though not subject to any SIP planning deadlines under the Clean Air Act, CDPHE has three emission reduction stakeholder processes underway, including: 1) the Statewide Hydrocarbon Emission Reduction (SHER) group, which is examining hydrocarbon emission reductions measures across the oil and gas sector, from upstream activities all the way through final transmission to the consumer; 2) the Pneumatics Taskforce, which is collecting data on the operation of pneumatic controllers and considering the best methods to ensure proper operation of those controllers; and 3) architectural coatings and consumer products stakeholder process, which is considering additional limits on the VOC content of various products offered for sale in Colorado. The SHER group and the Pneumatics Taskforce were set up by the Commission ${ }^{4}$ and designed to continue from 2018 through early 2020. Separately, the RAQC, working closely with CDPHE, has established three emission reduction committees, which are taking a comprehensive look at other additional emission control strategies that could be adopted for both stationary and mobile sources of emissions. Completing all these assessments, and developing the type of comprehensive emission reduction plan necessary to achieve meangingful and lasting reductions in ozone levels will take time. It would significantly curtail the ability of these groups to be

\footnotetext{
${ }^{4}$ These groups were set up by the Commission during the November 2017 rulemaking whereby the Commission adopted additional control measures on Colorado's oil and gas sector.
}

4300 Cherry Creek Drive South, Denver, CO 80246-1530 P 303-692-2000 www.colorado.gov/cdphe John W. Hickenlooper, Governor | Karin McGowan, Interim Executive Director 
successful if Colorado is denied the 1-year attainment date extension or is required to submit a Serious SIP before these groups can finish their work.

In order to further demonstrate Colorado's ongoing SIP planning efforts, Colorado notes that it has begun plan development activities associated with a Serious classification. ${ }^{5}$ The RAQC is already under contract with a technical consultant to perform any photochemical modeling needed for a Serious SIP attainment demonstration. ${ }^{6}$ Colorado's consultant is in the process of building a new modeling platform and developing a modeling protocol, which is expected to be finished within the next few months. This platform will be used for both a Serious SIP attainment demonstration for the 2008 NAAQS, and a potential Moderate SIP attainment demonstration for the 2015 NAAQS. ${ }^{7}$ Before the modeling can commence, Colorado must complete emission inventory work. CDPHE is working internally and with stakeholders in gathering emission inventory data for these modeling efforts, and is seeking to have this inventory finalized in January 2019. As EPA is aware, ozone photochemical modeling is extremely complex and time-consuming. The modeling assessments needed to evaluate whether the DMNFR will attain the 2008 NAAQS by the Serious area attainment date is expected to proceed throughout 2019. In the event that the modeling does not show attainment, additional modeling will be needed using the reduction strategies identified by the stakeholder groups and committees discussed above. All of this is a multi-year process, which cannot be reasonably completed by early 2020 .

Accordingly, as detailed below, CDPHE and the RAQC request that, consistent with the requirements of the Clean Air Act, EPA grant the proposed 1-year extension, and establish a coordinated SIP submittal schedule that will allow Colorado to develop the type of comprehensive plan necessary to successfully come into compliance with both the 2008 and 2015 NAAQS.

\section{Colorado's Attainment Date Extension Request}

The DMNFR was designated as a Marginal nonattainment area under the 2008 NAAQS, effective July 20,2012. ${ }^{8}$ The DMNFR failed to meet its July 20, 2015 attainment deadline ${ }^{9}$ and was reclassified as a Moderate nonattainment area, effective June $3,2016 .{ }^{10}$ Following the reclassification, Colorado adopted and submitted to EPA a SIP revision with additional ozone control measures, including reasonably available control technology (RACT), and a demonstration that the DMNFR would not exceed the 2008 NAAQS in $2017 .{ }^{11}$ Colorado's modeling proved reasonably accurate, and on June 4, 2018, Colorado submitted to EPA a demonstration that no monitor in the DMNFR had recorded any values that exceeded the 2008 NAAQS in

\footnotetext{
${ }^{5}$ See Procedures for Processing Bump Ups and Extension Requests for Marginal Ozone Nonattainment Areas, from D. Kent Berry, dated February 3, 1994. Colorado isn't clear that this Memorandum applies to the DMNFR, which is not a Marginal area for the 2008 standard, but nonetheless offers the demonstration recommended therein.

${ }^{6}$ The RAQC, as the lead air quality planning agency for Colorado, is the agency that contracts for all ozone modeling. CDPHE does reimburse the RAQC for some of the costs incurred in performance of that modeling.

${ }^{7}$ This modeling work further supports Colorado's request, discussed in more detail later in this comment letter, to align the timing of Serious SIP submittals for the 2008 NAAQS with that of Moderate SIP submittals for the 2015 NAAQS. Because modeling is not required for marginal nonattainment areas, it is arguably not as consistent with Section 182(i) to align a Serious SIP submittal for the 2008 NAAQS with a Marginal SIP submittal for the 2015 NAAQS.

${ }^{8} 2008$ Ozone NAAQS Designations, 77 Fed. Reg. 30,088 (May 21, 2012)

${ }^{9}$ EPA initially set an attainment deadline of December 31, 2015, but this was changed to July 20, 2015 after litigation. 2008 Ozone NAAQS Implementation Rule, 77 Fed. Reg. 30,160 (May 21, 2012); Nat. Res. Def. Council v. EPA, 777 F.3d 456 (D.C. Cir. 2014).

${ }^{10}$ Reclassification of Several Areas for the 2008 Ozone NAAQS, 81 Fed. Reg. 26,697 (May 4, 2016).

${ }^{11}$ EPA has approved the majority of Colorado's Moderate area SIP, including the attainment demonstration. See Approval and Promulgation of State Implementation Plan Revisions, 83 Fed. Reg. 31,068 (July 3, 2018).
}

4300 Cherry Creek Drive South, Denver, CO 80246-1530 P 303-692-2000 www.colorado.gov/cdphe John W. Hickenlooper, Governor | Karin McGowan, Interim Executive Director 
$2017,{ }^{12}$ and that it has complied with all recuirements and commitments in its applicable SIP. Colorado therefore asked for a 1-year extension of the DMNFR's attainment date - from July 20, 2018 to July 20, 2019.

In the Determinations, the EPA proposes to grant this 1-year attainment date extension for the DMNFR, to find that Colorado has complied with all requirements and commitments pertaining to the DMNFR in its applicable SIP, and to establish a new attainment date of July 20, 2019 for the DMNFR. ${ }^{13}$ The Clean Air Act provides that the EPA may, upon application by any State, extend for 1 year the area's attainment date if: (A) the State has complied with all requirements and commitments pertaining to the area in the applicable implementation plan; and (B) no more than 1 exceedance of the NAAQS has occurred in the area in the preceding year. ${ }^{14}$

With respect to the first prong, the D.C. Circuit Court of Appeals has upheld EPA's decision to rely on a state's certification of compliance with its SIP to satisfy this requirement of the Clean Air Act. ${ }^{15}$ The D.C. Circuit explicitly held that "EPA's presumptive reliance on state certification is reasonable because it is an efficient allocation of the agency's limited resources and personnel...and because EPA retains discretion to look beyond the certification if other evidence gives it reason to doubt the certification's credibility." Colorado's June 4, 2018 submittal contains a certification that the DMNFR is in compliance with the applicable SIP, and therefore meets this requirement.

With respect to the second prong, the EPA has promulgated a regulation providing for how it will determine whether an area has measured an exceedance of the NAAQS. Therein, the EPA has stated that a nonattainment area will meet the requirement for purposes of qualifying for the extension so long as the area's $4^{\text {th }}$ highest daily maximum average in the attainment year (here, 2017) is 0.075 parts per million or less. ${ }^{16}$ In its June 4, 2018 letter, Colorado certified that it met this requirement.

Colorado understands that two nongovernmental entities have requested a public hearing to object to the EPA's proposal to grant this extension to Colorado. Colorado further understands that one basis for their objection is that the DMNFR does not qualify for the second available extension, and therefore should not be granted the first extension. Eligibility is set out separately for the first extension and the second extension, and neither Congress nor the EPA tied availability of the first extension to an area's qualification for the second extension. Further, the federal regulation provides that an area "will meet" the second prong if it satisfies the requirements of the regulation (which the DMNFR does). Thus the EPA cannot deny the extension for reasons not cited in the regulation. For all these reasons, because the DMNFR has satisfied the criteria as set forth in the Clean Air Act and implementing regulations, the DMNFR is presumptively entitled to the extension.

\footnotetext{
${ }^{12}$ This demonstration is based, in part, on EPA's concurrence into two wildfire-related exceptional events. See July 11, 2018 letter from Martin Hesmark, Assistant Regional Administrator, to Garry Kaufman, Air Pollution Control Division Director, concurring with CDPHE's request to exclude ozone data related to wildfire smoke events on September 2 and 4, 2017. Pursuant to 40 C.F.R. $\$ 50.14(b)(1)$, once the EPA has determined that a State satisfies the requirements for an exceptional event as stated in that section (which it did in the July concurrence letter), the EPA "shall exclude" that data from determinations such as the one at issue here.

${ }^{13}$ Determinations, 83 Fed. Reg. at 56,784.

${ }^{14} 42$ U.S.C. $\$ 7511(\mathrm{a})(5)$.

${ }^{15}$ Delaware Dept. of Nat. Resources and Environmental Control v. EPA, 895 F.3d 90, 101-102 (D.C. Cir. 2018).

${ }^{16} 40$ C.F.R. $\$ 51.1107(a)(1)$.
}

4300 Cherry Creek Drive South, Denver, CO 80246-1530 P 303-692-2000 www.colorado.gov/cdphe John W. Hickenlooper, Govemor | Karin McGowan, Interim Executive Director 
Submittal Timing for Serious Area SIP Elements

In the Determinations, the EPA offers different timelines for submittal of various SIP elements upon reclassification of specified areas to Serious. These timelines apply to the areas proposed for reclassification in the Determinations, not the DMNFR. However, Colorado has been advised by EPA Region 8 that should the DMNFR ultimately be reclassified to Serious, the same timelines could be applied. Therefore, EPA Region 8 requested that Colorado submit its comments on EPA's proposal at this time.

Colorado notes that it has an extensive history of bringing nonattainment areas into attainment. Further, it is Colorado's intention to prepare and submit a SIP as protective of public health as is feasible given the timing prescribed by the EPA. Shorter timeframes are less protective of public health, in that control measures that secure real reductions take significant time and effort to develop, adopt, and implement.

\section{Non-RACT Serious Area SIP Revisions, SIP Revisions, and Implementation Deadline for RACT Tied to Attainment ${ }^{17}$}

Colorado agrees with much of EPA's discussion regarding the Clean Air Act deadlines for Serious SIP submittals. Specifically, Colorado agrees that Section 182(c) of the Clean Air Act, 42 U.S.C. $\$ 7511$ a(c), provides that attainment demonstrations and reasonable further progress demonstrations will be submitted within 4 years after November 15, 1990, and that the November 1990 reference here has been interpreted to refer to the initial designation of an area as nonattainment under a given standard. ${ }^{18}$ For the DMNFR, which was designated nonattainment for the 2008 NAAQS in 2012, that deadline has passed. In circumstances such as these, EPA has maintained that it has the "authority to adjust the applicable deadlines for the [area to be reclassified] 'as necessary or appropriate to assure consistency among the required submissions." ${ }^{19}$ Colorado further agrees that as a result, the EPA has discretion in setting deadlines for submittal of Serious SIP elements, bounded by the direction of the Clean Air Act to ensure consistency among required SIP submissions for that area. ${ }^{20}$

EPA has proposed to require submittal within 12 months of the effective date of reclassification the Serious SIP requirements except for those RACT proposals a State has determined are not tied to attainment. ${ }^{21}$ Colorado maintains that because EPA is directed to streamline SIP submittals when it considers

${ }^{17}$ Determinations, 83 Fed. Reg. at 56,788.

${ }^{18} 42$ U.S.C. $\$ 7511 \mathrm{la}(\mathrm{c})(2)$; see also 40 C.F.R. $\$ 51.1108(\mathrm{~b})$.

${ }^{19}$ See, e.g., Determinations of Attainment by the Attainment Date, Extensions of the Attainment Date, and Reclassification of Several Areas for the 2008 Ozone National Ambient Air Quality Standards, 81 Fed. Reg. 26,697 at 26,699 (May 4, 2016); Determination of Nonattainment and Reclassification of the Houston-Galveston-Brazoria 20088 Hour Ozone Nonattainment Area; Texas, 81 Fed. Reg. 66,240 at 66,242 (Sept. 27, 2016).

${ }^{20}$ See 42 U.S.C. $\$ 7511 \mathrm{a}$ (i).

${ }^{21}$ While not a direct comment on EPA's proposal, Colorado notes that in contrast with EPA's description in the Determinations, it believes that to the extent proposed control measures do not expedite attainment (and cannot be implemented before the ozone season of the attainment year), those measures are not RACT for purposes of Section 182. The EPA has advised that it considers Section 182(b)(2) RACT (applicable to Serious areas pursuant to Section 182(c)) distinguishable from RACT required under Section 172(c)(1), 42 U.S.C. $\$ 7502$ (c)(1). EPA has allowed that control measures that do not expedite attainment by the attainment date are not considered Section 172 RACT. NRDC v. EPA, 571 F.3d 1245 (D.C. Cir. 2009). EPA has also articulated that measures can be Section 182 RACT even if they don't expedite attainment, and even if they cannot be implemented by the deadlines specified in federal regulations (see 40 C.F.R. $\$ \$ 51.1108(d)$ and 51.1112 (a)(3)), if they are technologically and economically feasible, and it reiterates this distinction in the Determinations. It is Colorado's position that the Section 182 RACT requirement must be interpreted consistently with Section 172 because Section 182(b)(2) requires that the state submit a SIP "to include provisions to

4300 Cherry Creek Drive South, Denver, CO 80246-1530 P 303-692-2000 www.colorado.gov/cdphe John W. Hickenlooper, Governor | Karin McGowan, Interim Executive Director 
appropriate deadlines, EPA should instead set a deadline for Serious SIP submittals under the 2008 NAAQS consistent with the Moderate SIP submittals that will be due for the DMNFR under the 2015 NAAQS. This is consistent with the approach for which EPA solicits comment for the implementation of RACT for Serious areas. The areas being reclassified to Serious include the areas classified as Marginal under the 2015 NAAQS that are also likely to be reclassified to Moderate under the 2015 NAAQS. Because there are no significant planning or SIP requirements for Marginal areas, and no RACT requirements at all, it is more consistent with the language of Section 182(i) to align the timing of SIP submittals with the requirements for Moderate areas under the 2015 NAAQS. This alignment would result in significant savings of Colorado's limited resources, as Colorado would therefore only need to develop one SIP for submittal to EPA. Further, Colorado could use its resources to consider and propose more significant emission reduction measures than it might otherwise be able to get approved with more limited timing.

As a second alternative, Colorado suggests that the language in the Clean Air Act and implementing regulations requiring submittal of Serious SIP elements within 4 years of November 15, 1990 be interpreted to require submittal of Serious SIP elements within 4 years of reclassification (instead of initial designation, as discussed above). Colorado recognizes that the EPA has previously indicated that it does not believe it has the authority to interpret the Clean Air Act in this manner. ${ }^{22}$ However, EPA cited no authority for that proposition, nor is Colorado aware of any authority or reasoning supporting this conclusion. This interpretation maintains as much consistency as possible with the plain language of the Clean Air Act itself.

Notwithstanding the foregoing, if EPA finalizes the Determinations as proposed, Colorado requests that the EPA clarify that the DMNFR would, similarly with the areas proposed for reclassification in the Determinations, be given 12 months from the effective date of reclassification of the DMNFR in which to submit its Serious SIP, and not held to a submittal deadline in early 2020. Colorado is concerned that if and when the DMNFR is reclassified to Serious, the EPA would apply the Determinations to mandate submittal of a Serious SIP essentially concurrently with (or even prior to) that reclassification. Assuming that the EPA finalizes the Determinations in the next month or two, the deadline for Serious SIP submittals for areas reclassified now will fall in the January-February 2020 timeframe. Pursuant to the Clean Air Act, if Colorado does not qualify for a second 1-year clean data extension under Section 181(a)(5), Colorado could be reclassified to Serious in January 2020. If Colorado is required to submit its Serious SIP elements at the same time as areas being reclassified in the Determinations, it is possible that Colorado's deadline for submittal would pass before the DMNFR is reclassified, which puts Colorado in an untenable situation.

Further, Colorado has an unusual statutory requirement for SIPs - each SIP adopted by the Commission must go through a legislative SIP review process. ${ }^{23}$ CDPHE submits newly adopted SIPs to the Colorado Legislature at the beginning of the legislative session in January, and the SIP review process may not conclude until close of session in May. In order to meet a SIP submittal deadline of January 2020, Colorado would therefore have to have its SIP approved by the RAQC ${ }^{24}$ and the Commission in 2018, to undergo legislative review in 2019. As it is now December of 2018, Colorado cannot meet such a timeframe.

require the implementation of [RACT] under section 7502(c)(1) of this title...." EPA cannot ignore the plain language of Section 182(b)(2), which directly references Section 172(c)(1), in applying the RACT requirement. Colorado's position here further supports a single deadline for submittal of all Serious SIP elements, which Colorado proposes to be aligned with the Moderate area SIP elements due under the 2015 NAAQS. Notwithstanding the foregoing, Colorado's comments speak to the separate timing proposed by the EPA in the Determinations.

${ }^{22}$ See 81 Fed. Reg. at 26,699 (May 4, 2016).

${ }^{23}$ See $\$ 25-7-133$, C.R.S.

${ }^{24}$ The RAQC is the lead air planning agency pursuant to Colorado law, and SIPs must be presented to the RAQC for approval prior to being adopted by the Commission.

4300 Cherry Creek Drive South, Denver, CO 80246-1530 P 303-692-2000 www.colorado.gov/cdphe John W. Hickenlooper, Governor | Karin McGowan, Interim Executive Director 
It is Colorado's position that a January or February 2020 deadline for submittal of Serious SIP elements for the DMNFR would essentially be impossible for Colorado to meet, and therefore would be arbitrary and capricious.

For all the foregoing reasons, Colorado requests that the EPA align the submittal of all Serious SIP elements for the 2008 NAAQS with the submittal of Moderate SIP elements for the 2015 NAAQS. At a minimum, though, Colorado requests that it be granted at least 12 months from the effective date of the reclassification of the DMNFR to Serious in which to submit the Serious SIP elements required of areas being reclassified in the Determinations.

\section{RACT SIP Revisions Not Required for Attainment}

In the Determinations, EPA proposes a submittal deadline of August 3, 2020 for RACT SIPs for sources with VOC and/or NOx emissions between 50 to 100 tpy (i.e. Serious area major sources not addressed in the Moderate area RACT SIP submittal). ${ }^{25}$ EPA states that this deadline will be approximately 18 months from the effective date of final reclassification to Serious. ${ }^{26}$ If the same timeline is applied to the DMNFR, this deadline would only be approximately 6 months after the reclassification of the DMNFR to Serious.

EPA notes that this timing would align with "some" of the SIP submittal deadlines for the 2015 NAAQS. ${ }^{27}$ While Colorado will need to prepare a new emissions inventory and submit an emissions statement, there are no substantive SIP submittal deadlines that exist in August of 2020 for the DMNFR ${ }^{28}-a$ Marginal nonattainment area for the 2015 NAAQS. Certainly, no RACT SIP is required for a Marginal area. ${ }^{29}$ The purpose of Section 182(i) - ensuring consistency among required SIP submissions - is accomplished for RACT SIP submittals only if the RACT SIP submittal for the 2008 NAAQS is aligned with the RACT SIP submittal for the 2015 NAAQS.

EPA then points to the Clean Air Act provisions for ozone transport regions, Clean Air Act Section 184(b)(1), 42 U.S.C. $\$ 7511$ c(b)(1), which requires RACT SIP submittals within 2 years "after November 15, 1990." EPA solicits comment on whether to afford areas reclassified in the Determinations the full 2 years from effective date of reclassification to Serious for submittal of these Serious area RACT elements. ${ }^{30}$ While Section 184(b)(1) does not apply to the DMNFR, because the DMNFR is not in the ozone transport region, this timeframe is consistent with the deadline for Section $182 \mathrm{RACT} .{ }^{31}$ Colorado continues to assert that aligning the Serious SIP submittal timeframe - especially for RACT - with the Moderate SIP submittal timeframe for the 2015 standard is the appropriate course of action. However, in the alternative, Colorado

${ }^{25}$ Determinations, 83 Fed. Reg. at 56,788.

${ }^{26} I d$.

${ }^{27} \mathrm{Id}$.

${ }^{28}$ Colorado has already adopted its infrastructure SIP for the 2015 NAAQS. Colorado plans to submit the emission statement and the baseline inventory as required.

${ }^{29} 42$ U.S.C. $\$ 7511$ a(a); compare with 42 U.S.C. $\$ 7511 \mathrm{a}(\mathrm{b})(2)$. See also Implementation of the 2015 National Ambient Air Quality Standards for Ozone: Nonattainment Area: State Implementation Plan Requirements, prepublication notice published on Nov. 7, 2018 at Page 49 ("The [Clean Air] Act does not require implementation of RACM/RACT in Marginal ozone nonattainment areas under the relevant implementation provisions in subpart 2.")

${ }^{30}$ As discussed above, Colorado asserts that the EPA should interpret "November 15, 1990 " to mean the effective date of reclassification in all contexts related to submittals following reclassification, including this one.

${ }^{31} 42$ U.S.C. $\$ 7511 \mathrm{a}(\mathrm{b})(2)$.

4300 Cherry Creek Drive South, Denver, C0 80246-1530 P 303-692-2000 www.colorado.gov/cdphe John W. Hickenlooper, Governor | Karin McGowan, Interim Executive Director

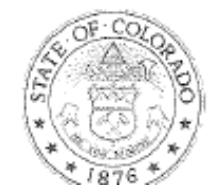


requests that EPA afford it 2 years (or at least 18 months) from the effective date of reclassification of the DMNFR to Serious in which to submit its Serious RACT SIP.

\section{Implementation Deadline for Additional Serious Area RACT}

In the Determinations, EPA is proposing two alternate timeframes for implementation of the control measures adopted as RACT. One possibility identified is that implementation would be required concurrently with the SIP submittal deadline - August 3,2020. The other alternative identified is that implementation would be required no later than January $1^{\text {st }}$ of the fifth year following reclassification (i.e. January 1,2024 ), which aligns with the RACT implementation deadline for areas that will be reclassified as Moderate under the 2015 standard. $^{32}$

Colorado believes that the second alternative is both preferable and more consistent with the Clean Air Act. Alignment of the submittal deadlines of the RACT SIP for areas reclassified to Serious under the 2008 standard with the RACT SIP for areas reclassified to Moderate under the 2015 standard preserves economy of resources and time. The extended timeframe also will allow Colorado to identify, adopt, and implement measures that ensure real reductions of ozone precursors and move the needle towards attainment of the NAAQS (which is, and should be, the real focus of the SIP program). Colorado just went through this process to implement RACT for major sources over 100 tpy in the DMNFR. Reclassification to Serious will result in an additional 600 major sources in the DMNFR. If RACT for sources newly classified as major (i.e. 50-100 tpy) must be implemented by August 3,2020, it is unlikely that Colorado can consider any measures not already in place for sources over 100 tpy. Moreover, Colorado has identified additional types of major sources of VOC and $\mathrm{NO}_{\mathrm{x}}$ between 50-100 tpy for which there were none over 100 tpy, for which it will have to develop RACT without the benefit of its previous efforts. Evaluating existing and potential control measures for each of these sources will be a challenge, let alone developing additional control measures where possible within the limited time proposed in the Determinations. Colorado spent more than a year evaluating RACT for its 53 current major sources, and two additional years developing additional control measures for a smaller subset of these major sources to further support its Moderate area RACT SIP. As a result, Colorado cannot realistically identify, adopt, and implement new control measures that secure real reductions where necessary from its major sources by August 2020, even if it begins this effort today. ${ }^{33}$

\section{Conclusion}

As reflected by its consistent and often-times ground-breaking emission reduction efforts since EPA's promulgation of the $2008 \mathrm{NAAQS}$, Colorado is committed to moving aggressively to bring down ozone levels in the DMNFR in order to protect the health of Colorado's citizens. In order for Colorado to be successful in meeting this objective, EPA needs to establish a reasonable SIP submittal schedule for the State consistent with the requirements of the Clean Air Act. Absent the granting of the proposed 1-year extension and alignment of the SIP submittal deadlines under the 2008 and 2015 NAAQS, Colorado faces the prospect of being required to submit three separate ozone SIPs within the next four years. This will entail a monumental administrative burden that will severly undermine the ability of Colorado to develop and implement signifcant ozone precursor reduction strategies.

\footnotetext{
${ }^{32}$ This proposed timing also aligns with previous EPA actions with respect to implementation of control measures for Serious areas under the PM-2.5 NAAQS. See 40 C.F.R. $\$ 51.1010$.

${ }^{33}$ Colorado notes that it's effort to identify sources and to begin to analyze potential controls is underway already, but, as described above, Colorado is currently prioritizing emission control strategies that obtain real ozone precursor reductions over formal development of a Serious SIP because those two efforts cannot both proceed full steam ahead on parallel tracks given Colorado's resources. Colorado seeks EPA support for its approach.
}

4300 Cherry Creek Drive South, Denver, CO 80246-1530 P 303-692-2000 uww.colorado.gov/cdphe John W. Hickenlooper, Govemor | Karin McGowan, Interim Executive Director 
Accordingly, Colorado requests that the EPA grant the proposed 1-year extension and set one deadline for submittal of the DMNFR's Serious SIP and implementation of RACT, consistent with the deadlines that would be applicable to the DMNFR upon reclassification to Moderate for the 2015 NAAQS. This alignment serves the purpose and direction of the Clean Air Act - to allow States the ability to identify control measures that will truly make progress towards attainment of the NAAQS, and to set deadlines consistently amongst required submittals to minimize planning and administrative burdens, while maximizing Colorado's ability to develop the type of comprehensive emission reduction plan necessary to achieve our common objective of coming into compliance with both the 2008 and 2015 NAAQS.

Please contact counsel for the Colorado Air Pollution Control Division, Robyn Wille, at robyn.wille@coag.gov, with comments or questions regarding this letter.

Sincerely,

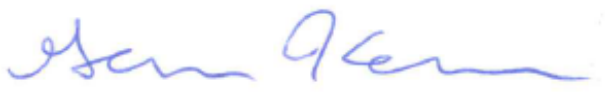

Garry Kaufman

Director, Air Pollution Control Division

Colorado Department of Public Health and Environment

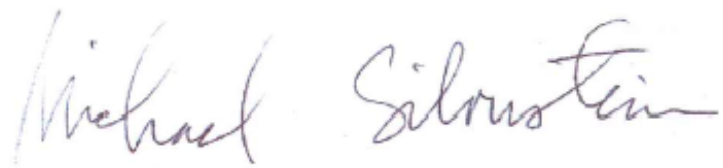

Mike Silverstein
Executive Director
Regional Air Quality Council

cc: (via email)

Martha Rudolph, Director of Environmental Programs, CDPHE

Doug Benevento, Regional Administrator, EPA Region 8 
1344 Background ozone was estimated from the data presented in Table 2 [Bien and Helmig, 2018]. We considered the median summer ozone values for sites that are not located within large cities, and at $<2000$ $m$ elevation. Below is a partial reproduction of that table, with those considered sites highlighted in turquoise. For comparison, the same analysis is also provided for DMA/NCFR suburban sites. Coordinates, elevation, and a map showing all sites are available in [Bien and Helmig, 2018].

\section{SM_Table 1} daily median and $95^{\text {th }}$ percentile summer amplitude of every site with data available for $2011-2015$.

\begin{tabular}{|c|c|c|c|}
\hline $\begin{array}{l}\text { Site } \\
\text { No }\end{array}$ & Site Name & $\begin{array}{c}\text { Median Sum- } \\
\text { mer } \mathrm{O}_{3} \\
\text { [ppbv] }\end{array}$ & $\begin{array}{c}95^{\text {th }} \text { Percentile } \\
\text { Summer } \mathrm{O}_{3} \\
{[\mathrm{ppbv}]}\end{array}$ \\
\hline 1 & Welby & 37 & 69 \\
\hline 2 & Highland Reservoir & 49 & 73 \\
\hline 3 & Aurora East & 49 & 68 \\
\hline 4 & Eldora Ski Area & 58 & 76 \\
\hline 5 & South Boulder Creek & 43 & 71 \\
\hline 6 & Boulder Fire Station & 32 & 57 \\
\hline 7 & Longmont & 36 & 72 \\
\hline 8 & Trout Creek Pass & 50 & 65 \\
\hline 10 & Goliath Peak & 54 & 70 \\
\hline 11 & Mount Evans & 62 & 77 \\
\hline 12 & Mines Peak & 49 & 65 \\
\hline 13 & Denver - Camp & 35 & 62 \\
\hline 14 & Denver - Carriage & 41 & 72 \\
\hline 15 & Denver - Animal Shelter & 38 & 67 \\
\hline 16 & La Casa & 35 & 66 \\
\hline 18 & Chatfield Reservoir & 46 & 75 \\
\hline 19 & U.S. Air Force Acad. & 45 & 68 \\
\hline 20 & Manitou Springs & 47 & 68 \\
\hline 21 & Rifle - Health Dept. & 35 & 59 \\
\hline 23 & Flattops \#3 & 52 & 64 \\
\hline 24 & Ripple Creek Pass & 51 & 64 \\
\hline 25 & Sunlight Mountain & 58 & 73 \\
\hline 26 & Wilson & 50 & 65 \\
\hline 27 & Battlement Mesa & 43 & 62 \\
\hline 28 & Glenwood Springs & 33 & 55 \\
\hline 29 & Carbondale & 32 & 54 \\
\hline 30 & McClure Pass & 48 & 60 \\
\hline 31 & Gothic & 41 & 59 \\
\hline 32 & Walden - Chandler Ranch & 37 & 57 \\
\hline 33 & Arvada & 40 & 74 \\
\hline 34 & Welch & 44 & 71 \\
\hline 35 & Rocky Flats & 50 & 76 \\
\hline 36 & Golden - NREL & 48 & 75 \\
\hline 38 & Aspen Park & 46 & 67 \\
\hline 39 & Shamrock Station & 48 & 65 \\
\hline 40 & Ignacio & 37 & 64 \\
\hline 41 & Bondad & 39 & 64 \\
\hline 42 & RMNP - Long's Peak & 51 & 70 \\
\hline
\end{tabular}




\begin{tabular}{|c|c|c|c|}
\hline 43 & Fort Collins - West & 45 & 73 \\
\hline 44 & Rist Canyon & 46 & 68 \\
\hline 45 & Fort Collins - CSU & 37 & 66 \\
\hline 46 & RMNP - Collocated & 49 & 68 \\
\hline 47 & Palisade & 45 & 62 \\
\hline 48 & Grand Mesa & 53 & 64 \\
\hline 49 & Silt - Collbran & 50 & 64 \\
\hline 50 & CO Nat. Mon. & 49 & 64 \\
\hline 51 & Lay Peak & 44 & 61 \\
\hline 52 & Elk Springs & 41 & 56 \\
\hline 53 & Cortez & 40 & 61 \\
\hline 54 & Mesa Verde NP & 50 & 64 \\
\hline 56 & Kenosha Pass & 49 & 63 \\
\hline 57 & Fairplay & 43 & 60 \\
\hline 58 & Ajax Mountain & 54 & 66 \\
\hline 59 & Aspen & 40 & 58 \\
\hline 61 & CO Plant Science Bldg. & 41 & 58 \\
\hline 62 & Rangely & 44 & 61 \\
\hline 64 & Norwood & 44 & 62 \\
\hline 67 & Greeley - Weld Cty Twr & 43 & 71 \\
\hline 68 & Briggsdale & 41 & 64 \\
\hline 69 & Pawnee Buttes & 47 & 65 \\
\hline 70 & Boulder - INSTAAR & 39 & 65 \\
\hline 71 & Sugar Loaf Fire Dept. & 40 & 65 \\
\hline 72 & Coughlin Meadows & 45 & 64 \\
\hline 73 & Lyons & 45 & 71 \\
\hline 74 & Dawson School & 40 & 67 \\
\hline 75 & Lost Angels Fire Dept. & 46 & 66 \\
\hline 76 & Boulder Atmos. Obs. & 41 & 68 \\
\hline 77 & Niwot Ridge - Tundra & 59 & 74 \\
\hline 78 & Niwot Ridge - C1 & 48 & 66 \\
\hline 79 & Niwot Ridge - Soddie & 47 & 62 \\
\hline 80 & Dinosaur Nat. Mon. & 45 & 64 \\
\hline
\end{tabular}

Background Sites (turquoise):

$$
\text { Range of highlighted sites: }
$$

32-49 ppb

$54-65 \mathrm{ppb}$

Median of highlighted sites:

Mean of highlighted sites:

$\begin{array}{ll}41 \mathrm{ppb} & 62 \mathrm{ppb} \\ 41 \mathrm{ppb} & 61 \mathrm{ppb}\end{array}$

1361 Suburban Front Range Sites (yellow):

1362 Range of highlighted sites:

1363 Median of highlighted sites:

1364 Mean of highlighted sites:

$\begin{array}{rr}43-50 \mathrm{ppb} & 71-76 \mathrm{ppb} \\ 46 \mathrm{ppb} & 73 \mathrm{ppb} \\ 46 \mathrm{ppb} & 73 \mathrm{ppb}\end{array}$

\section{Supplemental Materials Citations}

1368 Bien, T., and D. Helmig (2018), Changes in summertime ozone in Colorado during 2000-2015, Elementa1369 Science of the Anthropocene, 6, 1-25, doi:10.1525/elementa.300. 